\title{
Copper Minerals at Vesuvius Volcano (Southern Italy): A Mineralogical Review
}

\author{
Giuseppina Balassone ${ }^{1,2, *}$, Carmela Petti ${ }^{3}$, Nicola Mondillo ${ }^{1,4}$, Taras L. Panikorovskii ${ }^{5,6}$ (D), \\ Roberto de Gennaro ${ }^{1}$, Piergiulio Cappelletti ${ }^{1,3}$, Angela Altomare ${ }^{7}$, Nicola Corriero ${ }^{7}$, \\ Maria Cangiano ${ }^{8}$ and Loredana $\mathrm{D}^{\prime}$ Orazio $^{2}$ \\ 1 Dipartimento di Scienze della Terra, dell'Ambiente e delle Risorse, Università Federico II, \\ Complesso Universitario Monte S. Angelo, Via Cintia 21, 80126 Napoli, Italy; \\ nicola.mondillo@unina.it (N.M.); roberto.degennaro@unina.it (R.d.G.); piergiulio.cappelletti@unina.it (P.C.) \\ Istituto per i Polimeri, Compositi e Biomateriali, CNR, Viale Campi Flegrei 34, 80078 Pozzuoli, Italy; \\ loredana.dorazio@ipcb.cnr.it \\ 3 Centro Museale "Centro Musei delle Scienze Naturali e Fisiche”, Università Federico II, Via Mezzocannone 8, \\ 80134 Napoli, Italy; petti@unina.it \\ 4 Department of Earth Sciences, Natural History Museum, Cromwell Road, London SW7 5BD, UK \\ 5 Kola Science Centre, Russian Academy of Sciences, 14 Fersman Street, Apatity 184200, Russia; \\ taras.panikorovsky@spbu.ru \\ 6 Department of Crystallography, St. Petersburg State University, 7-9 Universitetskaya Naberezhnaya, \\ St. Petersburg 199034, Russia \\ 7 Istituto di Cristallografia, CNR, Via Amendola 122/O, 70126 Bari, Italy; angela.altomare@ic.cnr.it (A.A.); \\ nicola.corriero@ic.cnr.it (N.C.) \\ 8 Via Isernia 3, 80026 Casoria, Italy; maria.cangiano@hotmail.it \\ * Correspondence: balasson@unina.it
}

Received: 17 October 2019; Accepted: 21 November 2019; Published: 26 November 2019

\begin{abstract}
This work is part of a project focused on the Somma-Vesuvius volcano and aimed at identifying $\mathrm{Cu}$ minerals related to mineralizing processes associated with magmatic activity in an active magmatic-hydrothermal system. A mineralogical survey was carried out on a set of samples represented by sublimates and fumarolic products from the collection of the Mineralogical Museum of the University of Naples Federico II (Italy). These samples are mainly related to most recent eruptive episodes of Vesuvius activity, from 1631 onward. Copper-bearing minerals were characterized, as well as associated minerals, by X-ray diffraction (XRD) scanning electron microscopy with energy dispersive X-ray spectroscopy (SEM-EDS). An investigation on the structural complexity of Cu-mineral assemblages with different temperature formations was also carried out using the TOPOS software package. The main copper phases are sulfates, followed by vanadates, hydroxyhalides, oxides, carbonates, silicates and finally, phosphates. New mineral occurrences for Vesuvius, both Cu-bearing and $\mathrm{Cu}$-free, are described. Nevertheless, the fumarolic/alteration minerals at Vesuvius cannot be considered of economic relevance as a copper reservoir, this type of mineralizations are significant for copper crystal chemistry and for the knowledge of the mineralogical variants. The obtained datasets can be of interest for the knowledge of volcanic byproducts of copper ore deposits (i.e., porphyry copper systems) and of (base) metal segregation processes.
\end{abstract}

Keywords: copper minerals; Somma-Vesuvius; Italy; volcano sublimates; fumarolic minerals; alteration products 


\section{Introduction}

Copper is a base metal and the 26th most abundant element in the Earth's crust, with concentrations ranging from 26 to $28 \mathrm{ppm}$ in the continental crust [1] and less than $44 \mathrm{ppm}$ in the lower oceanic crust [2]. As a transition metal, $\mathrm{Cu}$ is moderately siderophile and strongly chalcophile, with approximately two thirds of terrestrial $\mathrm{Cu}$ thought to be stored in the core [3]. In the silicate Earth, it behaves as a chalcophile element and usually forms stable sulfides, among which chalcopyrite $\left(\mathrm{CuFeS}_{2}\right)$ is the most common Cu-bearing mineral; copper is also a common constituent, together with silver, in natural sulfosalts [4]. However, in nature, copper occurs in a great variety of minerals; according to the mindat.org database [5], it is essentially contained in 562 valid mineral species, in decreasing order of abundance, hosted in sulfides-sulfosalts, phosphates-arseniates-vanadates, sulfates, oxides, halides, silicates, carbonates, borates and native elements. According to Pekov and co-workers, at least 690 mineral species can be described, of which $\mathrm{Cu}$ prevails over the other constituents in one independent position in the crystal structure [6].

Copper is an economically important base metal. It forms large and rich ore deposits with exceptional mineral diversity; major ore sulfide minerals include, in addition to the aforementioned chalcopyrite $\mathrm{CuFeS}_{2}(35 \% \mathrm{Cu})$, bornite $\mathrm{Cu}_{5} \mathrm{FeS}_{4}(63 \% \mathrm{Cu})$, covellite $\mathrm{CuS}(66 \% \mathrm{Cu})$ and chalcocite $\mathrm{Cu}_{2} \mathrm{~S}$ $(80 \% \mathrm{Cu})$. About three-quarters of the world's copper is provided by porphyry copper systems [7], mainly centered on calc-alkaline porphyry magmatic systems in subduction zone settings ([8,9] and references therein). Lesser but significant contributions come from massive sulfide, skarn, and other types of deposits. The top $\mathrm{Cu}$ producers are Chile, USA, Indonesia and Peru [7,9].

Somma-Vesuvius is an active Quaternary volcano which belong to the alkaline potassic-ultrapotassic Roman Magmatic Province of southern Italy. Here, copper is associated with historically active fumaroles and occurs in a variety of minerals, primarily sulfates and halides, but also in silicates, carbonates, sulfides, oxides and vanadates and commonly as encrustations and patinas on lavas [10-15]. The majority of $\mathrm{Cu}$-bearing minerals are sulfates and halides, followed by silicates, carbonates, sulfides, oxides and vanadates, which commonly occur as encrustations and patinas on lavas. The present work represents the starting point of a large project focused on the Somma-Vesuvius volcano and aimed at identifying $\mathrm{Cu}$ minerals related to mineralization processes associated with magmatic activity in an active magmatic-hydrothermal system (porphyry-like?) and augmenting the understanding of geodiversity within this unusual paragenetic environment. This first step deals with a mineralogical survey of a set of samples represented by sublimation and fumarolic products belonging to the vast sample collection of the Mineralogical Museum of the University of Naples Federico II (Italy). These samples are mainly related to most recent eruptive episodes of Vesuvius activity, from 1631 onward, and were catalogued among the specimens containing one or more $\mathrm{Cu}$-bearing phases. Together with the copper-bearing minerals, a characterization of the associated minerals has also been carried out in order to give a more complete overview of the whole assemblages. Similar crystal-chemical investigations are ongoing on Somma-Vesuvius Cu-bearing samples/assemblages of different types, not only fumaroles/encrustations/sublimates-related. Hence, the final aim will be to discuss the nature of $\mathrm{Cu}$-bearing minerals and associations in the context of the related mineralizing events.

\section{Geological and Volcanological Setting of Somma-Vesuvius and Mineralogical Background}

Somma-Vesuvius (Figure S1) is a moderate size stratovolcano consisting of an older edifice dissected by a summit caldera, i.e., Mt Somma, and a recent cone, i.e., Vesuvius that grew within the caldera. It is located in the Campanian plain, bordering the bay of Naples. The complexity of this area and its evolution are connected to the tectonic evolution of the southern Apennine chain of the Italian peninsula, related to the opening of the Tyrrhenian basin during Plio-Pleistocene ([16] and references therein). The formation of the Campanian plain was accompanied by the uplift of the central part of the southern Apennines, in a regional stress regime generating NW-SE and NE-SW-trending faults and establishing the conditions for magma formation and rising to the surface. With the exception of 
the oldest volcanic rocks with calc-alkaline composition, erupted magmas younger than $400 \mathrm{ka}$ are alkaline; at Vesuvius, the composition of volcanic products is mainly potassic to high potassic. Mt Somma consists of a pile of thin lava flows interbedded with spatter and cinder deposits post-dating the 39 ka old Campanian ignimbrite of Campi Flegrei $[17,18]$. The caldera is a nested poly-phased structure which is formed by several collapses related to the main explosive eruptions [19]. About $22 \mathrm{ka}$ ago, the mainly effusive activity of Mt Somma abruptly changed into highly explosive activity, with the occurrence of high-magnitude plinian eruptions, i.e., Pomici di Base, Greenish pumice, Mercato (8.9 ka) and Avellino (3.9 ka) [20-29]. Activity became more frequent after the Avellino pumice, with at least eight explosive eruptions and some lava flows which preceded the 79 AD Pompeii pumice eruption [23].

The Vesuvius edifice began to form after $79 \mathrm{AD}$, growing discontinuously during periods of open-conduit activity. High intensity, explosive eruptions sporadically occurred, the two largest being the subplinian events of 472 AD (Pollena eruption) and 1631. The most recent period (1631-1944) was characterized by alternating strombolian activity and violent eruptions; a detailed study on the eruptions ages of the recent activity (mainly post-1631) is given, among others, by Arrighi et al. ([30] and references therein). Summit or lateral lava effusions and semi-persistent mild explosive activity with small lava fountains occurred, together with gases and vapor emission from the crater, interrupted by pauses lasting from months to a maximum of seven years. In the recent period, the eruption of 1906 is the largest explosive eruption of the twentieth century. At the end of the eruption, the top of the cone was truncated, with the formation of a vast crater ([11] and references therein). The Vesuvius area was characterized by quiescent periods alternated by prolonged volcanic activity, effusions of lava and low energy explosions after this explosive event. The last eruption of Vesuvius occurred in March 1944. The 1944 eruption marked the end of an open-conduit phase and the beginning of a quiescence period with obstructed conduit. Presently, Mt. Vesuvius is in a quiescent period and affected by relatively low level volcanic-hydrothermal activity in the inner slopes and the bottom of the crater. According to Caliro et al. [13] the activity is mainly characterized by (i) widespread fumarolic emissions, accompanied by diffuse soil $\mathrm{CO}_{2}$ degassing in the crater area, and (ii) $\mathrm{CO}_{2}$-rich groundwaters along the southern flank of Vesuvius and in the adjacent plain and seismic activity with epicentres clustered inside the crater. Fumarolic fluids discharging by the crater rim fumaroles are of relatively low temperatures $\left(<75^{\circ} \mathrm{C}\right)$ and are mainly composed of atmospheric components. Fumaroles from the crater bottom have $\mathrm{H}_{2} \mathrm{O}$ and $\mathrm{CO}_{2}$ as major components, followed by $\mathrm{H}_{2}, \mathrm{H}_{2} \mathrm{~S}, \mathrm{~N}_{2}$, $\mathrm{CH}_{4}, \mathrm{CO}$, and $\mathrm{He}$ (in order of decreasing content), and undetectable $\mathrm{SO}_{2}, \mathrm{HCl}$, and $\mathrm{HF}$ and a discharge temperature of about $95^{\circ} \mathrm{C}$ [13]. The chemical composition of the fumaroles of the crater bottom relate to the hydrothermal type, with the typical presence of $\mathrm{H}_{2} \mathrm{~S}$ [14]. According to Chiodini et al. [14], $\mathrm{CH}_{4}$ and $\mathrm{NH}_{3}$ contents suggest that the origin of these fluids is related to a high-temperature hydrothermal system located underneath the Vesuvius crater area. These authors argued that $\mathrm{NaCl}$ brines reside in the high-temperature reservoir and have an influence on the chemical composition of the gases discharged by the fumaroles of the crater bottom. Fumarolic $\mathrm{H}_{2} \mathrm{O}$ is either meteoric water, enriched in ${ }^{18} \mathrm{O}$ through high-temperature water-rock oxygen isotope exchange, or a mixture of meteoric and arc-type magmatic water. Fumarolic $\mathrm{CO}_{2}$ is mainly generated by decarbonation reactions of marine carbonates, but the addition of small amounts of magmatic $\mathrm{CO}_{2}$ is also possible. Regarding the magma composition, the Somma-Vesuvius products display, with very few exceptions, a potassic to ultrapotassic composition, exhibiting a wide variability from nearly silica-saturated to silica-undersaturated. Joron et al. [31] and Ayuso et al. [32] distinguished three different groups of rocks: (i) slightly silica-undersaturated, older than the Mercato eruption (35 to $18 \mathrm{ka}$ ); (ii) mildly silica-undersaturated, from the Mercato to the Pompeii (79 AD) eruptions (10 to $2 \mathrm{ka}$ ); (iii) highly silica-undersaturated, younger than Pompeii eruption. Variations in the content of some major and trace elements are consistent with this division (e.g., [32]), although the general incompatible trace element patterns remain similar among rocks of these three periods of activity ([16] and references therein). 
As already mentioned, the vast majority of the Cu-bearing minerals at Vesuvius are found in alteration products, encrustations and sublimate formations deposited at the fumarolic vents, mainly related to most recent eruptive episodes of Vesuvius activity, from 1631 onward [10-12,33,34]. An overview of the fumarolic minerals in the main European active volcanic provinces (Italy, Iceland, Greece), including Somma-Vesuvius, was carried out by Balić-Žunić et al. [35]. Remarkably, Pekov et al. [6] have recently carried out a very important crystal-chemical survey on the copper minerals from volcanic exhalations occurring in active areas; this work mainly deals with the copper mineralization in the Tolbachik volcano (Kamchatka, Russia), the "word-record-holder" of the fumarolic copper minerals, with 90 different minerals found there, of which Tolbachik is the type locality.

A first detailed study of fumarolic mineral assemblages vs. temperature (T) conditions at Somma-Vesuviusis due to Lacroix [36], who divided fumarole activities into four typologies [10-12]:

1. High $\mathrm{T}$ fumaroles, with $\mathrm{Na}$ and $\mathrm{K}$-bearing salts, with temperature $>650{ }^{\circ} \mathrm{C}$, i.e., the so-called Deville's "dry fumaroles" [37]. The most important minerals are chlorides and alkali sulfates (halite, sylvite, thenardite, aphthitalite, etc). At a lower temperature, the mineral variety increases and $\mathrm{Cu}-\mathrm{Cl}$ oxyhalides and hydroxyhalides prevail (eriochalcite, paratacamite, melanothallite), minerals formed by sulfuric acid (chalcocyanite, dolerophanite, euchlorine, chlorothionite and secondary chalcanthite), tenorite [as a result of $\mathrm{H}_{2} \mathrm{O}$ (gas) and $\mathrm{CuCl}_{2}$ (gas) interaction], $\mathrm{Pb}$-bearing minerals, like cotunnite and rarely, pseudocotunnite and palmierite; in the 1906 eruption, abundant galena also formed, together with pyrite, chalcopyrite, pyrrhotite, magnetite and hematite. The lowest temperature recorded for this kind of fumaroles is between 300 and $400{ }^{\circ} \mathrm{C}$;

2. Acid fumaroles (the Deville's "acid fumaroles"), which follow the previous ones after magma cooling. Chloride minerals are present, as molisite, chloraluminite, erythrosiderite, kremersite, along with realgar and native sulfur. Their temperature is between 100 and $300{ }^{\circ} \mathrm{C}$;

3. Fumaroles with salammoniac with ammonium sulfates and fluorides (the Deville's "water vapor and salammoniac-bearing fumaroles"), found almost exclusively on the lower part of lava flows, rarely close to the crater $\left(\mathrm{T} \approx 300^{\circ} \mathrm{C}\right)$. The most abundant mineral is salammoniac and in small amounts, mascagnite and chryptohalite also occur;

4. Sulfur-bearing low $\mathrm{T}$ fumaroles (the Deville's "water vapor and and $\mathrm{H}_{2} \mathrm{~S}+$ native S-bearing fumaroles"; [11] and references therein), with T rarely $>100^{\circ} \mathrm{C}$; these fumaroles follow the acid ones and are characterized by abundant $\mathrm{H}_{2} \mathrm{O}$ (gas) with variable quantity of $\mathrm{H}_{2} \mathrm{~S}$. Silicates of the host rocks are transformed to opal, and the most abundant minerals are native sulfur, gypsum, $\mathrm{K}-\mathrm{Al}-\mathrm{Fe}$ sulfates [alunogen, alum-(K), metavoltine and voltaite] and sassolite.

The post-1944 fumaroles were studied, in particular, by Parascandola [38], who reported maximum temperatures of about $800{ }^{\circ} \mathrm{C}$ down to $460{ }^{\circ} \mathrm{C}$ between 1948 and 1960 [14,39-41]. The current temperatures of the fumaroles at the eastern rim of the crater are between $70{ }^{\circ} \mathrm{C}$ and $80{ }^{\circ} \mathrm{C}$ [41]. Chiodini et al. [14] reported a chronogram of the maximum temperatures measured in the crater area after the last eruption, which took place in 1944; this chronogram clearly shows a hot period from 1944 to 1960 when temperatures of 600 to $800^{\circ} \mathrm{C}$ were recorded, followed by a cold period. Temperatures close to the boiling point of water at the crater level $\left(95^{\circ} \mathrm{C}\right)$ were attained during the 1990 s. This temperature decline was accompanied by remarkable changes in the mineralogy of sublimates and alteration products deposited at the fumarolic vents $[10,38]$. Oxide of $\mathrm{Cu}$ (tenorite), as well as $\mathrm{Na}$ chloride (halite) and $\mathrm{Pb}$ (cotunnite) and were the most important minerals at temperatures of 500 to $800^{\circ} \mathrm{C}$, whereas the present mineral assemblage includes sulfur, gypsum, and sulfates, such as alunite, alum-(K), metavoltine, pickeringite, and halotrichite [14].

According to the literature $[10,11]$, a number of $\mathrm{Cu}$-bearing minerals, as malachite, azurite and cuprorivaite and also some chalcopyrite occurrences were detected in Somma ejecta or lavas as well. A list of the Cu-bearing minerals found at Somma-Vesuvius so far is given in Table 1. It is worth noting the occurrence of thirteen type locality (or co-type locality) copper species, ranging from sulfides to silicates. 
Table 1. Summary of the Cu-bearing minerals of Somma-Vesuvius from the literature $[5,10,34]$.

\begin{tabular}{|c|c|c|c|c|c|}
\hline Systematics & Name & Formula & Location $^{1}$ & & Occurrence $^{2}$ \\
\hline \multirow{2}{*}{ sulfides } & chalcopyrite & $\mathrm{CuFeS}_{2}$ & Mt. Somma & & leuco-tephritic ejecta, fumaroles, scoriae cavities of 1906 eruption \\
\hline & covellite & $\mathrm{CuS}$ & Atrio del Cavallo & TL & 1823 and 1906 fumaroles \\
\hline \multirow{9}{*}{ halides } & ammineite & $\mathrm{CuCl}_{2} \cdot 2 \mathrm{NH}_{3}$ & Vesuvius & & post-1944 fumaroles \\
\hline & atacamite & $\mathrm{Cu}_{2}(\mathrm{OH})_{3} \mathrm{Cl}$ & Vesuvius & & green patinas in 1631 lavas, 1872 lavas, 1906 lavas \\
\hline & cumengeite & $\mathrm{Pb}_{21} \mathrm{Cu}_{20} \mathrm{Cl}_{42}(\mathrm{OH})_{40} \cdot 6 \mathrm{H}_{2} \mathrm{O}$ & Vesuvius & & LT fumaroles \\
\hline & eriochalcite & $\mathrm{CuCl}_{2} \cdot 2 \mathrm{H}_{2} \mathrm{O}$ & Vesuvius & $\mathrm{TL}$ & 1869 HT fumaroles \\
\hline & hydromelanothallite & $\mathrm{Cu}_{2}(\mathrm{OH})_{2} \mathrm{Cl}_{2} \cdot \mathrm{H}_{2} \mathrm{O}$ & Vesuvius & & \\
\hline & melanothallite & $\mathrm{Cu}_{2} \mathrm{OCl}_{2}$ & Vesuvius & $\mathrm{TL}$ & 1869 HT fumaroles \\
\hline & mitscherlichite & $\mathrm{K}_{2} \mathrm{CuCl}_{4} \cdot 2 \mathrm{H}_{2} \mathrm{O}$ & Vesuvius & $\mathrm{TL}$ & fumaroles, Vesuvius crater \\
\hline & paratacamite & $(\mathrm{Cu}, \mathrm{Zn})_{2}(\mathrm{OH})_{3} \mathrm{Cl}$ & Vesuvius & & 1944 fumaroles, alteration of piypite \\
\hline & tondiite & $\mathrm{Cu}_{3} \mathrm{Mg}(\mathrm{OH})_{6} \mathrm{Cl}_{2}$ & Vesuvius & $\mathrm{co}-\mathrm{TL}$ & 1906 lava \\
\hline \multirow{2}{*}{ oxides } & cuprite & $\mathrm{Cu}_{2} \mathrm{O}$ & Vesuvius & & encrustations with tenorite (lavas of Camaldoli) \\
\hline & tenorite & $\mathrm{CuO}$ & Vesuvius & TL & 1760 scoriae, HT fumaroles of $1825,1826,1855,1872,1906,1929,1944$ \\
\hline \multirow{2}{*}{ carbonates } & azurite & $\mathrm{Cu}_{3}\left(\mathrm{CO}_{3}\right)_{2}(\mathrm{OH})_{2}$ & Vesuvius & & 1631 lavas, 1872 lavas \\
\hline & malachite & $\mathrm{Cu}_{2}\left(\mathrm{CO}_{3}\right)(\mathrm{OH})_{2}$ & Mt. Somma & & clinopyroxene-rich ejectum, Pollena \\
\hline \multirow{11}{*}{ sulfates } & antlerite & $\mathrm{Cu}_{3} \mathrm{SO}_{4}(\mathrm{OH})_{4}$ & Vesuvius & & alteration of dolerophanite by $\mathrm{H}_{2} \mathrm{SO}_{4}$ in fumaroles \\
\hline & brochantite & $\mathrm{Cu}_{4}\left(\mathrm{SO}_{4}\right)(\mathrm{OH})_{6}$ & Vesuvius & & post-1944 fumaroles \\
\hline & chalcanthite & $\mathrm{CuSO}_{2} \cdot 5 \mathrm{H}_{2} \mathrm{O}$ & Vesuvius & & $1855,1872,1881,1895,1906,1944$ fumaroles \\
\hline & chalcocyanite & $\mathrm{CuSO}_{4}$ & Vesuvius & $\mathrm{TL}$ & 1868 HT fumaroles \\
\hline & chlorothionite & $\mathrm{K}_{2} \mathrm{CuSO}_{4} \mathrm{Cl}_{2}$ & Vesuvius & TL & encrustations in 1872 lavas \\
\hline & connellite & $\mathrm{Cu}_{19}\left(\mathrm{SO}_{4}\right)(\mathrm{OH})_{32} \mathrm{Cl} \cdot 3 \mathrm{H}_{2} \mathrm{O}$ & Vesuvius & & 1872 fumaroles \\
\hline & cyanochroite & $\mathrm{K}_{2} \mathrm{Cu}\left(\mathrm{SO}_{4}\right) \cdot 6 \mathrm{H}_{2} \mathrm{O}$ & Vesuvius & TL & $1855,1872,1906$ fumaroles \\
\hline & dolerophanite & $\mathrm{Cu}_{2} \mathrm{OSO}_{4}$ & Vesuvius & $\mathrm{TL}$ & 1868 fumaroles \\
\hline & euchlorine & $\mathrm{KNaCu}_{3} \mathrm{O}\left(\mathrm{SO}_{4}\right)_{3}$ & Vesuvius & $\mathrm{TL}$ & $1868,1892,1893$ fumaroles \\
\hline & linarite & $\mathrm{CuPbSO}_{4}(\mathrm{OH})_{2}$ & Vesuvius & & 1881-1882 scoriae \\
\hline & piypite & $\mathrm{K}_{4} \mathrm{Cu}_{4} \mathrm{O}_{2}\left(\mathrm{SO}_{4}\right)_{4}(\mathrm{Na}, \mathrm{Cu}) \mathrm{Cl}$ & Vesuvius & & 1869 fumaroles \\
\hline \multirow{2}{*}{ vanadates } & mottramite & $\mathrm{PbCu}\left(\mathrm{VO}_{4}\right)(\mathrm{OH})$ & Vesuvius & & \\
\hline & volborthite & $\mathrm{Cu}_{3} \mathrm{~V}_{2} \mathrm{O}_{7}(\mathrm{OH})_{2} \cdot 2\left(\mathrm{H}_{2} \mathrm{O}\right)$ & Vesuvius & & 1631 and 1868 lavas \\
\hline \multirow{3}{*}{ silicates } & chrysocolla & $\left(\mathrm{Cu}_{2-\mathrm{x}} \mathrm{Al}_{\mathrm{x}}\right) \mathrm{H}_{2-\mathrm{x}} \mathrm{Si}_{2} \mathrm{O}_{5}(\mathrm{OH})_{4} \cdot \mathrm{nH}_{2} \mathrm{O}$ & Vesuvius & & 1872 lava \\
\hline & cuprorivaite & $\mathrm{CaCuSi}_{4} \mathrm{O}_{10}$ & Vesuvius & $\mathrm{TL}$ & Vesuvian lavas (unknown locality) \\
\hline & litidionite & $\mathrm{KNaCuSi}_{4} \mathrm{O}_{10}$ & Vesuvius & TL & 1873 lapilli (Vesuvius crater) \\
\hline
\end{tabular}

${ }^{1} \mathrm{TL}=$ type locality or co-type locality. ${ }^{2}$ The ages of the occurrences refer to the cited literature. 


\section{Materials and Methods}

In the present study, we selected 32 samples (Table 2), all belonging to the "Vesuvian Collection" of the Mineralogical Museum of the Naples University (Italy), where copper minerals typically occur as encrustations and/or tiny patinas, coatings and/or void filling associated with the historical activity of Vesuvius. Museum samples were selected on the basis of the catalog description and/or a visual examination, trying to select promising and representative lithotypes. Hence, for this study, we considered small subsamples of each Museum specimen in order to preserve their integrity as much as possible. The studied fractions were carefully separated from the host rocks, trying to select those richer in copper minerals, at least at a first macro-to-mesoscopic evaluation. A further selection of different mineral assemblages was also carried out by means of a binocular stereo microscope for the subsequent mineralogical analyses.

Table 2. List of the investigated Somma-Vesuvius samples from the Mineralogical Museum of Naples University (Italy) with Cu-bearing minerals, faithfully reporting both the description and the locations (when present) reported in the original labels. Minerals in italics correspond to discredited species (see Table 3).

\begin{tabular}{|c|c|c|c|}
\hline$\#$ & Sample ID & Museum Classification & Location * \\
\hline 1 & A578 & Cu chloride & Vesuvius \\
\hline 2 & 5357 B2192 & chalcanthite & Vesuvius \\
\hline 3 & 10741 D1192 & chalcanthite & May 1855 \\
\hline 4 & 10817 D1268 & azurite & Vesuvius, 1631 lava (Scala) \\
\hline 5 & 10820 D127 & azurite & Vesuvius, 1631 lava (Scala) \\
\hline 6 & 10907 D1358 & $\begin{array}{c}\text { euchlorine with metamorphized } \\
\text { hydrocyanite }\end{array}$ & crater, February 1870 \\
\hline 7 & 11004 D1455 & conglomerate with cupromagnesite & ejecta, April 1872 \\
\hline 8 & 11061 D1512 & malachite, pseudocotunnite & Vesuvius crater, July 1875 \\
\hline 9 & 11269 D1720 & tenorite & crater, July 1881 \\
\hline 10 & 11271 D1722 & atelite & Vesuvius crater, June 1880 \\
\hline 11 & 12020 E559 & tenorite & Vesuvius crater, 1885 \\
\hline 12 & 12105 E644 & Cu-bearing cotunnite & $\begin{array}{l}\text { Vesuvius, March 1870, November } \\
1868 \text { lava, "Fosso della Vetrana" }\end{array}$ \\
\hline 13 & 12756 E1295 & $\begin{array}{l}\text { metamorphized hydrocyanite in } \\
\text { chalcanithe }\end{array}$ & Vesuvius crater, 1870 \\
\hline 14 & 12912 E1457 & euchlorine & Vesuvius, 1870 \\
\hline 15 & $16256 \mathrm{E} 6787$ & linarite & Vesuvius crater, 1882 \\
\hline 16 & 17004 E5543 & metamorphized tenorite (atelite) & Vesuvius crater, December 1872 \\
\hline 17 & 17029 E5568 & chlorothionite & Vesuvius crater, January 1873 \\
\hline 18 & 17030 E5569 & chlorothionite & Vesuvius crater, January 1873 \\
\hline 19 & 17032 E5571 & cupromagnesite & Vesuvius, April 1872 ejecta \\
\hline 20 & 17556 E6095 & tenorite & Vesuvius, 1872 lavas \\
\hline 21 & 17602 E6141 & $\mathrm{Cu}$-bearing anglesite & $\begin{array}{l}\text { Vesuvius, September } 1877 \\
\text { fumarole of } 1872 \text { lava }\end{array}$ \\
\hline 22 & 17718 E6249 & vesbine & Vesuvius, 1631 lava \\
\hline 23 & 17719 E6250 & vesbine & Vesuvius, 1631 lava (Camaldoli) \\
\hline 24 & 17722 E6253 & vesbine with atacamite & Vesuvius, 1631 lava (Uncino) \\
\hline 25 & 17724 E6255 & atacamite & Vesuvius, 1631 lava (Camaldoli) \\
\hline 26 & 17729 E6260 & greenish atacamite & Vesuvius, 1631 lava (Camaldoli) \\
\hline 27 & 17923 E6454 & neocyanite & Vesuvius crater, October 1880 \\
\hline 28 & 17926 E6457 & litidionite & Vesuvius crater, June 1873 \\
\hline 29 & 18531 E7062 & cuprite & Vesuvius, 1631 lava \\
\hline 30 & 21836 & tenorite & Vesuvius, 1906 eruption \\
\hline 31 & 21846 & anglesite & Vesuvius, 1906 eruption \\
\hline 32 & 21911 & metamorphosed hydrocyanite & $\begin{array}{l}\text { Vesuvius, eruptive vent at the } \\
\text { cone base, August } 1891\end{array}$ \\
\hline
\end{tabular}

* The timing indicated here refers to both the eruptions age (i.e., 1631 lava) and to the entry dates in the Museum collection (i.e., January 1873). 
Due to the high solubility in water of many minerals (i.e., soluble salts), likely forming the various associations, polished sections were prepared by using only oil-based suspensions and pastes and/or ethyl alcohol for sample preparation and final cleaning. Mineralogical analyses were carried out by X-ray powder diffraction (XRD) using a Seifert-GE ID3003 diffractometer, with CuK $\alpha$ radiation, Ni-filtered at $40 \mathrm{kV}$ and $30 \mathrm{~mA}$, in the $3-80^{\circ} 2 \theta$ range, a step scan $0.02^{\circ}$, and time of $10 \mathrm{~s} / \mathrm{step}$ at the Dipartimento di Scienze della Terra, dell'Ambiente e delle Risorse (DiSTAR) University of Naples Federico II (Italy), and the RayfleX (GE) software package. The identification of different phases in multimineralic samples by XRD was sometimes tricky due to reflections overlapping.

Few selected samples were analyzed at the Institute of Crystallography of CNR (IC-CNR, Bari, Italy) and their X-ray powder diffraction patterns were collected at room temperature by using an automated Rigaku RINT2500 rotating anode laboratory diffractometer (50 kV, $200 \mathrm{~mA}$ ) equipped with the silicon strip Rigaku D/teX Ultra detector. An asymmetric Johansson Ge (111) crystal was used to select the monochromatic $\mathrm{Cu} K \alpha 1$ radiation $(\lambda=1.54056 \AA)$. Measurement was executed in the transmission mode by introducing the sample in a glass capillary ( $0.5 \mathrm{~mm}$ diameter) (put in rotation), which was mounted on the axis of the diffractometer. In order to reduce the effect of possible preferred orientation, the capillary was rotated during measurement to improve the randomization of the orientations of the individual crystallites. A qualitative phase analysis was carried out by the software QUALX2.0 [42], whereas structure solution was executed by the software EXPO [43].

Micromorphological and chemical analyses by scanning electron microscopy with energy dispersive X-ray spectroscopy (SEM-EDS) were also carried out using a JEOL JSM5310 electron microscope (located at DiSTAR) equipped with an Oxford energy dispersive spectrometry (EDS) INCA X-stream pulse processor and the 4.08 version Inca software. The operating conditions were an acceleration voltage of $15 \mathrm{kV}, 50-100 \mu \mathrm{A}$ filament current, variable spot size and a working distance of $20 \mathrm{~mm}$; the reference standards used for quantitative microanalysis were anorthoclase, $\mathrm{Si}, \mathrm{Al}$ and $\mathrm{Na}$; diopside, $\mathrm{Ca}$; microcline, $\mathrm{K}$; rutile, Ti; fayalite, Fe; olivine, $\mathrm{Mg}$; serandite, $\mathrm{Mn}$; sphalerite, $\mathrm{Zn}$; benitoite, $\mathrm{Ba}$; celestite, $\mathrm{Sr}$; fluorite, $\mathrm{F}$; halite, $\mathrm{Cl}$; pyrite, $\mathrm{S}$; galena $\mathrm{Pb}$; pure metal, $\mathrm{Cu}$. Detection limits of the analyzed elements are below $0.1 \%$.

The crystal structural representation was prepared via VESTA program [44]. Information-based complexity measures for crystal structures of minerals were calculated using TOPOS software [45] using the formula proposed in the [46]. The information about complexity $\mathrm{Cu}$-minerals from Vesuvio volcano is given in Table S1.

\section{Results}

\subsection{Characterization of the $\mathrm{Cu}$-Bearing Minerals}

Table 3 lists the Cu-bearing minerals cited in the text, as well as the correspondence with the obsolete names for some species of minerals and their ideal formulas.

Table 3. Chemical formula of the main Cu-bearing minerals found and/or cited in this study together with the obsolete names.

\begin{tabular}{ccc}
\hline Mineral & Discredited Name & Formula \\
\hline atacamite & & $\mathrm{Cu}_{2} \mathrm{Cl}(\mathrm{OH})_{3}$ \\
azurite & & $\mathrm{Cu}_{3}\left(\mathrm{CO}_{3}\right)_{2}(\mathrm{OH})_{2}$ \\
boothite & cupromagnesite & $\mathrm{CuSO}_{4} \cdot 7\left(\mathrm{H}_{2} \mathrm{O}\right)$ \\
brochantite & & $\mathrm{Cu}_{4}\left(\mathrm{SO}_{4}\right)(\mathrm{OH})_{6}$ \\
chalcanthite & & $\mathrm{CuSO}_{4} \cdot 5\left(\mathrm{H}_{2} \mathrm{O}\right)$ \\
chalcocyanite & hydrocyanite & $\mathrm{Cu}\left(\mathrm{SO}_{4}\right)$ \\
chlorothionite & & $\mathrm{K}_{2} \mathrm{Cu}\left(\mathrm{SO}_{4}\right) \mathrm{Cl}_{2}$ \\
chrysocolla & & $\left(\mathrm{Cu}_{2-\mathrm{x}} \mathrm{Al}_{\mathrm{x}}\right) \mathrm{H}_{2-\mathrm{x}} \mathrm{Si}_{2} \mathrm{O}_{5}(\mathrm{OH})_{4} \cdot \mathrm{nH}_{2} \mathrm{O}$ \\
cryptochalcite & & $\mathrm{K}_{2} \mathrm{Cu}_{5} \mathrm{O}\left(\mathrm{SO}_{4}\right)_{5}$ \\
cuprite & $\mathrm{Cu}_{2} \mathrm{O}$ \\
\hline
\end{tabular}


Table 3. Cont.

\begin{tabular}{|c|c|c|}
\hline Mineral & Discredited Name & Formula * \\
\hline cyanochroite & & $\mathrm{K}_{2} \mathrm{Cu}\left(\mathrm{SO}_{4}\right)_{2} \cdot 6 \mathrm{H}_{2} \mathrm{O}$ \\
\hline dravertite & & $\mathrm{CuMg}\left(\mathrm{SO}_{4}\right)_{2}$ \\
\hline euchlorine & & $\mathrm{KNaCu}_{3} \mathrm{O}\left(\mathrm{SO}_{4}\right)_{3}$ \\
\hline kröhnkite & & $\mathrm{Na}_{2} \mathrm{Cu}\left(\mathrm{SO}_{4}\right)_{2} \cdot 2 \mathrm{H}_{2} \mathrm{O}$ \\
\hline leightonite & & $\mathrm{K}_{2} \mathrm{Ca}_{2} \mathrm{Cu}\left(\mathrm{SO}_{4}\right)_{4} \cdot 2 \mathrm{H}_{2} \mathrm{O}$ \\
\hline linarite & & $\mathrm{PbCu}\left(\mathrm{SO}_{4}\right)(\mathrm{OH})_{2}$ \\
\hline litidionite & neocyanite & $\mathrm{KNaCuSi}_{4} \mathrm{O}_{10}$ \\
\hline malachite & & $\mathrm{Cu}_{2}\left(\mathrm{CO}_{3}\right)(\mathrm{OH})_{2}$ \\
\hline mottramite & vesbine & $\mathrm{PbCu}\left(\mathrm{VO}_{4}\right)(\mathrm{OH})$ \\
\hline natrochalcite & & $\mathrm{NaCu}_{2}\left(\mathrm{SO}_{4}\right)_{2}(\mathrm{OH}) \cdot \mathrm{H}_{2} \mathrm{O}$ \\
\hline paratacamite & atelite & $\mathrm{Cu}^{3+}{ }_{3}(\mathrm{Cu}, \mathrm{Zn})(\mathrm{OH})_{6} \mathrm{Cl}_{2}$ \\
\hline starovaite & & $\mathrm{KCu}_{5} \mathrm{O}\left(\mathrm{VO}_{4}\right)_{3}$ \\
\hline tenorite & & $\mathrm{CuO}$ \\
\hline tsumebite & & $\mathrm{Pb}_{2} \mathrm{Cu}\left(\mathrm{PO}_{4}\right)\left(\mathrm{SO}_{4}\right)(\mathrm{OH})$ \\
\hline volborthite & vesbine & $\mathrm{Cu}_{3} \mathrm{~V}_{2} \mathrm{O}_{7}(\mathrm{OH})_{2} \cdot 2 \mathrm{H}_{2} \mathrm{O}$ \\
\hline
\end{tabular}

* IMA database.

In Table 4, we report the assemblages of the $\mathrm{Cu}$-bearing minerals and associated minerals which refer to subsamples selected from the investigated museum specimens (Table 2).

Table 4. Cu-bearing mineral assemblages of the studied samples, mainly occurring as incrustation or patinas, carried out by combined SEM-EDS and XRD analyses.

\begin{tabular}{|c|c|c|}
\hline$\#$ & Sample ID & Main Mineral Assemblage * \\
\hline 1 & A578 & anglesite, atacamite, euchlorine \\
\hline 2 & 5357 B2192 & chalcanthite, natrochalcite, cryptochalcite, anglesite, halite, leightonite \\
\hline 3 & 10741 D1192 & chalcanthite, leghtonite, kröhnkite \\
\hline 4 & 10817 D1268 & azurite, atacamite, malachite \\
\hline 5 & 10820 D1271 & azurite, atacamite, chrysocolla, gypsum, calcite \\
\hline 6 & 10907 D1358 & chalcocyanite, atacamite, alunite, opal, anglesite, galena, euchlorine \\
\hline 7 & 11004 D1455 & atacamite, leightonite, sylvite, halite, gypsum \\
\hline 8 & 11061 D1512 & $\begin{array}{l}\text { atacamite, challacolloite, elpasolite, sylvite, fluorite, anglesite, } \\
\text { palmierite, gypsum, galena, paratacamite }\end{array}$ \\
\hline 9 & 11269 D1720 & $\begin{array}{c}\text { tenorite, anglesite, cryptochalcite, elpasolite, palmierite, gypsum, } \\
\text { anhydrite, thermessaite, kröhnkite }\end{array}$ \\
\hline 10 & 11271 D1722 & atacamite, halite, gypsum, fluorite \\
\hline 11 & 12020 E559 & tenorite, anglesite, hematite, elpasolite, fluorite, kröhnkite \\
\hline 12 & 12105 E644 & cotunnite, anglesite \\
\hline 13 & 12756 E1295 & $\begin{array}{c}\text { chalcanthite, chalcocyanite, cryptochalcite, anglesite, gypsum, halite, } \\
\text { kröhnkite, dravertite }\end{array}$ \\
\hline 14 & 12912 E1457 & $\begin{array}{c}\text { euchlorine, atacamite, anglesite, cryptochalcite, palmierite, barite, } \\
\text { natrochalcite }\end{array}$ \\
\hline 15 & $16256 \mathrm{E} 6787$ & $\begin{array}{l}\text { linarite, elpasolite, fluorite, anglesite, tenorite, paratacamite, } \\
\text { pyromorphite tsumebite brochantite sbacchiite hematite galena }\end{array}$ \\
\hline 16 & 17004 E5543 & atacamite, pseudocotunnite, tenorite \\
\hline 17 & 17029 E5568 & $\begin{array}{c}\text { atacamite, anglesite, sylvite, halite, syngenite, paratacamite, } \\
\text { challacolloite, chlorothionite }\end{array}$ \\
\hline 18 & 17030 E5569 & atacamite, elpasolite, sylvite, halite, fluorite, aphthitalite, chlorothionite \\
\hline 19 & 17032 E5571 & atacamite, sylvite, halite, challacolloite, boothite \\
\hline 20 & 17556 E6095 & tenorite, atacamite, sylvite, halite, fluorite \\
\hline 21 & 17602 E6141 & atacamite, anglesite, galena \\
\hline 22 & 17718 E6249 & mottramite, chrysocolla, vanadinite, wulfenite \\
\hline 23 & 17719 E6250 & tenorite, mottramite, chrysocolla, vanadinite, hematite \\
\hline 24 & 17722 E6253 & mottramite, atacamite, chrysocolla, starovaite, anglesite, gypsum \\
\hline 25 & 17724 E6255 & atacamite \\
\hline 26 & 17729 E6260 & atacamite \\
\hline 27 & 17923 E6454 & litidionite, calcinaksite, tridymite, wollastonite, diopside \\
\hline 28 & $17926 \mathrm{E} 6457$ & $\begin{array}{c}\text { litidionite, calcinaksite, tridymite, wollastonite, atacamite, sylvite, } \\
\text { glassy matrix }\end{array}$ \\
\hline 29 & 18531 E7062 & cuprite, atacamite, fluorite, volborthite \\
\hline 30 & 21836 & tenorite, anglesite, fluorite, halite, syngenite, linarite, thénardite, galena \\
\hline 31 & 21846 & anglesite, tenorite, atacamite, gypsum, challacolloite \\
\hline 32 & 21911 & $\begin{array}{c}\text { chalcocyanite, cyanochroite, leightonite, gypsum, cotunnite, anglesite, } \\
\text { thermessaite, alum-K, kröhnkite }\end{array}$ \\
\hline
\end{tabular}

${ }^{*}$ Minerals in Italics need to be validated. 
Due to the complex nature (i.e., too tiny grain size of crystals or intimate intergrowths in the micro-aggregates) and the great variety of the $\mathrm{Cu}$-bearing mineral associations, the mineralogical characterization was often tricky and hence, the identification of some phases was made by means of only a qualitative EDS analysis or a micro-morphological SEM evaluation, or, if possible XRD reflection(s), so that a more complete validation can be achieved.

\subsubsection{Hydroxylhalides}

The most abundant basic cupric chloride is atacamite (Tables 3 and 4). It was mainly found in green to blue-green-yellowish samples and rich in cupric chlorides at a visual examination, and occurs in three macroscopically different types (Figure 1): (i) green-blue-yellow thin crusts coating the lava host (Figure 1a,e,f), (ii) green encrustations of finely crystalline material (Figure 1c,d), (iii) small rounded microcrystalline masses, green in color, spread out on the external surface of the host rock (Figure 1b). Atacamite rarely occurs as well crystallized clusters (Figure 2a), whereas it commonly forms compact masses covering the external surfaces of lavas (ca. $100 \mu \mathrm{m}$ in thickness) or concretions in admixtures with chrysocolla (Figure $2 b-d$ ). The chemical composition of atacamite (Table 5) shows small amounts of $\mathrm{Fe}, \mathrm{Mg}, \mathrm{Mn}, \mathrm{Ca}$ and $\mathrm{Si}$, and more frequently, $\mathrm{Zn}$ contents (0.2-1.5 wt\% ZnO).
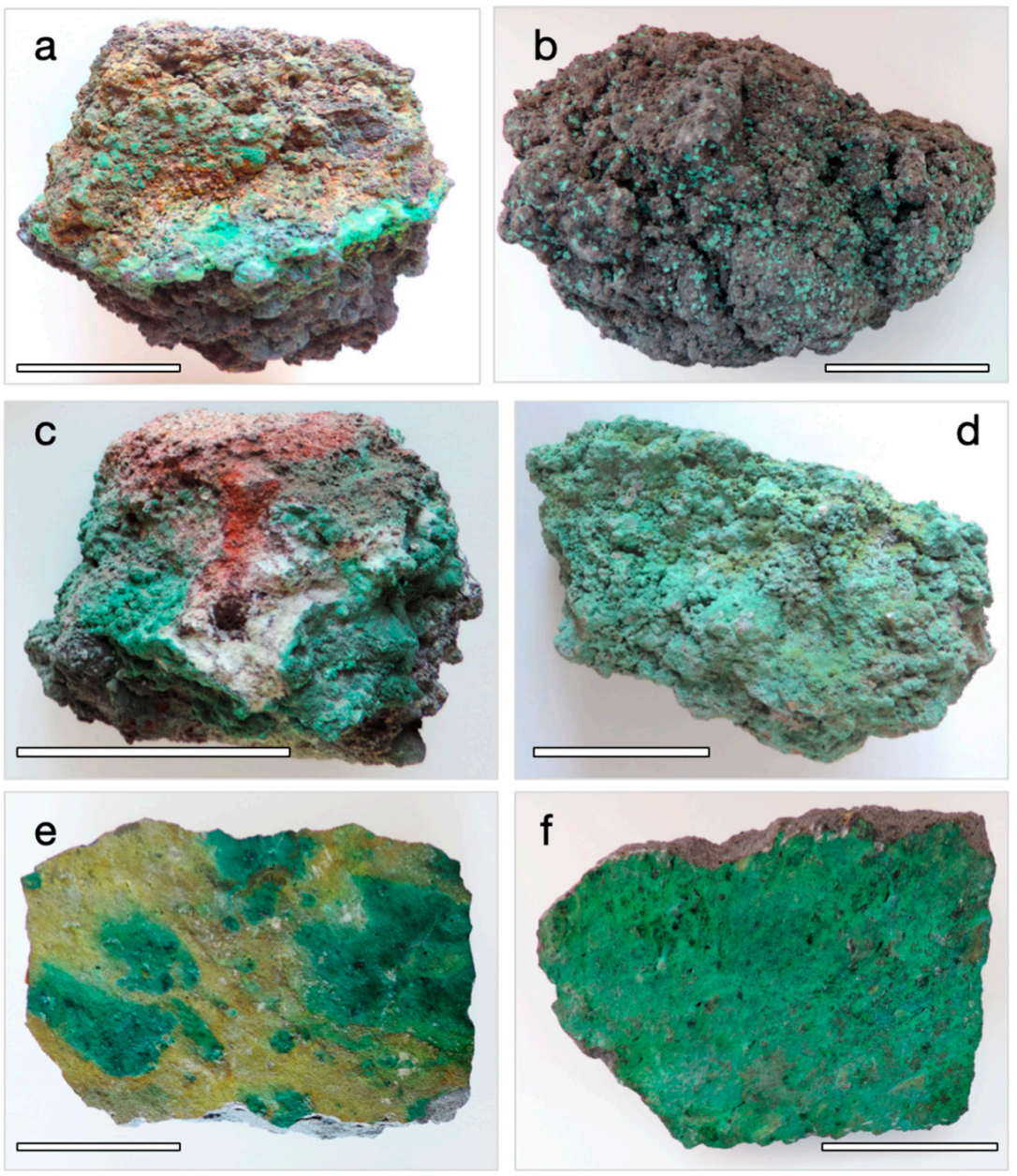

Figure 1. Macrophotos of selected samples with atacamite from the Somma-Vesuvius collection of the Mineralogical museum (Naples University, Italy): (a) atacamite (green parts), sample 11061 D1521; (b) atacamite with various halides, sample 11271 D1722; (c) atacamite (green spots) with different sulfates, sample 12912 E1457; (d) atacamite, sample 17032 E5571; (e) atacamite (green parts) with copper vanadates and silicates (yellowish parts), sample 17722 E6253; (f) atacamite-rich patina, 17724 E6255. The scale bar is $5 \mathrm{~cm}$. 
Paratacamite (corresponding to the discredited "atelite", Table 3) is very subordinate (Table 4). In sample $17029 \mathrm{E} 5568$, this hydroxysalt forms tiny euhedral crystals (Figure 2e), containing $6.25 \mathrm{wt} \%$ $\mathrm{ZnO}$ (ca. $5 \mathrm{wt} \% \mathrm{Zn}$, Table 5). In sample $16256 \mathrm{E} 6787$, paratacamite grows on tenorite and shows a lower content of $\mathrm{Zn}(2.54 \mathrm{wt} \% \mathrm{ZnO})$. In sample $11061 \mathrm{D} 1512$, a (weak) XRD reflection at $5.47 \AA$ was observed, and EDS spectra show the presence of Zn, which are consistent with paratacamite.
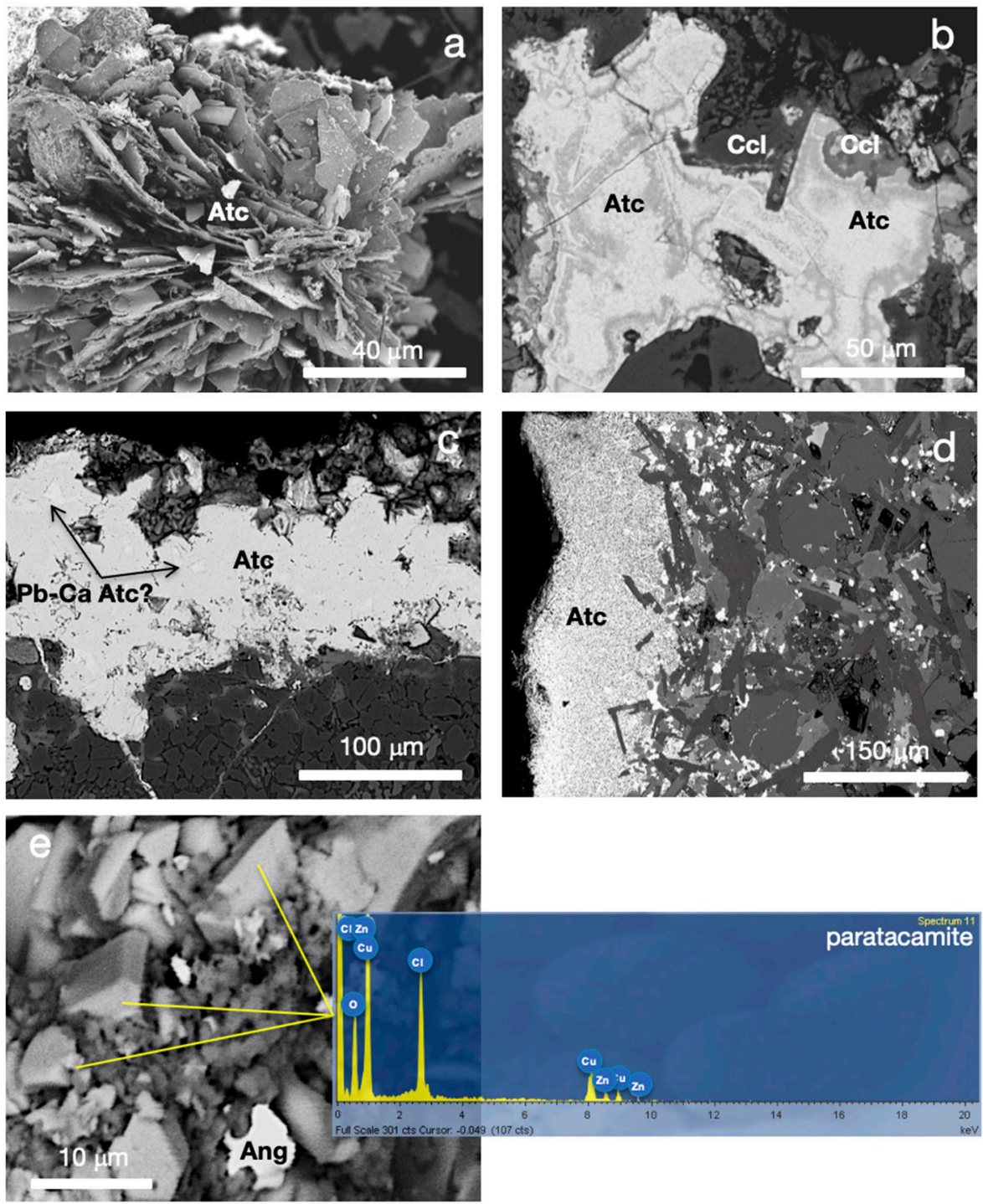

Figure 2. Copper basic chlorides in the studied Somma-Vesuvius samples. (a) SEM image of atacamite (Atc) in a well-crystallized aggregate (sample 17556 E6095); (b) backscatter-electron (BSE hereafter) image of atacamite, with chrysocolla (Ccl), observed in the polished section (sample 17722 E6253); (c) BSE image of atacamite with tiny inclusions (lighter grey) compositionally corresponding to a possible $\mathrm{Pb}-\mathrm{Ca}$-bearing atacamite (polished section, sample 17724 E6255); (d) BSE image of atacamite-rich band coating the lava sample (polished section, sample 17729 E6260); (e) SEM image of likely paratacamite crystals with the related EDS spectrum, associated with anglesite (Ang) and mixed sulfates (dark grey), sample 17029 E5568. Mineral abbreviations used here and hereafter are partly after Whitney and Evans [47]. 
Table 5. Representative results of SEM-EDS analyses of atacamite and paratacamite from Somma-Vesuvius.

\begin{tabular}{|c|c|c|c|c|c|c|c|c|c|c|c|c|c|c|}
\hline Sample ID & \multicolumn{3}{|c|}{108201271} & \multicolumn{3}{|c|}{11061 D17722 } & \multicolumn{3}{|c|}{17724 E6255 } & \multicolumn{3}{|c|}{17729 E6260 } & 16256 E6787 & 17729 E6260 \\
\hline $\mathrm{wt} \%$ & \multicolumn{12}{|c|}{ atacamite } & \multicolumn{2}{|c|}{ paratacamite } \\
\hline $\mathrm{CuO}$ & 72.04 & 72.47 & 74.63 & 71.58 & 72.00 & 73.55 & 72.23 & 74.32 & 73.69 & 75.23 & 74.50 & 75.22 & 69.05 & 68.07 \\
\hline $\mathrm{SiO}_{2}$ & - & - & 0.11 & - & - & - & - & - & - & 0.12 & 0.25 & - & - & - \\
\hline $\mathrm{Al}_{2} \mathrm{O}_{3}$ & - & 0.12 & 0.22 & - & - & - & - & - & - & - & - & - & - & - \\
\hline $\mathrm{CaO}$ & - & - & 0.13 & - & - & 0.30 & - & 0.68 & - & - & - & - & - & - \\
\hline $\mathrm{FeO}$ & 1.05 & - & - & - & 0.45 & 0.45 & - & - & - & 0.90 & 0.33 & - & 0.21 & 0.23 \\
\hline $\mathrm{MgO}$ & - & - & - & - & - & 0.11 & 0.78 & - & - & - & - & - & - & 0.12 \\
\hline $\mathrm{MnO}$ & - & 1.26 & - & - & - & 0.26 & 1.48 & 1.92 & - & 0.13 & - & - & - & 0.09 \\
\hline $\mathrm{ZnO}$ & 1.27 & 1.50 & 1.29 & 0.90 & - & 0.67 & - & 0.33 & 1.35 & - & 0.23 & 0.44 & 2.54 & 6.25 \\
\hline $\mathrm{Cl}$ & 17.01 & 17.11 & 17.34 & 16.60 & 17.05 & 16.56 & 17.36 & 17.34 & 17.13 & 17.00 & 16.87 & 16.64 & 16.00 & 16.34 \\
\hline Total & 91.37 & 92.46 & 93.72 & 89.08 & 89.50 & 91.90 & 91.86 & 94.60 & 92.17 & 93.38 & 92.18 & 92.30 & 87.80 & 91.10 \\
\hline \multirow{2}{*}{$-\mathrm{O}=\mathrm{Cl}_{2}$} & 3.84 & 3.87 & 3.92 & 3.75 & 3.85 & 3.74 & 3.92 & 3.92 & 3.87 & 3.84 & 3.81 & 3.76 & 3.62 & 3.69 \\
\hline & 87.52 & 88.59 & 89.80 & 85.33 & 85.65 & 88.16 & 87.93 & 90.68 & 88.30 & 89.54 & 88.37 & 88.54 & 84.18 & 87.41 \\
\hline
\end{tabular}

- below detection limit. 


\subsubsection{Oxides}

In the investigated samples, the copper oxides are represented by tenorite and cuprite (Table 3); tenorite was detected in eight samples, whereas cuprite in one specimen only (Table 4 and Figure 3).
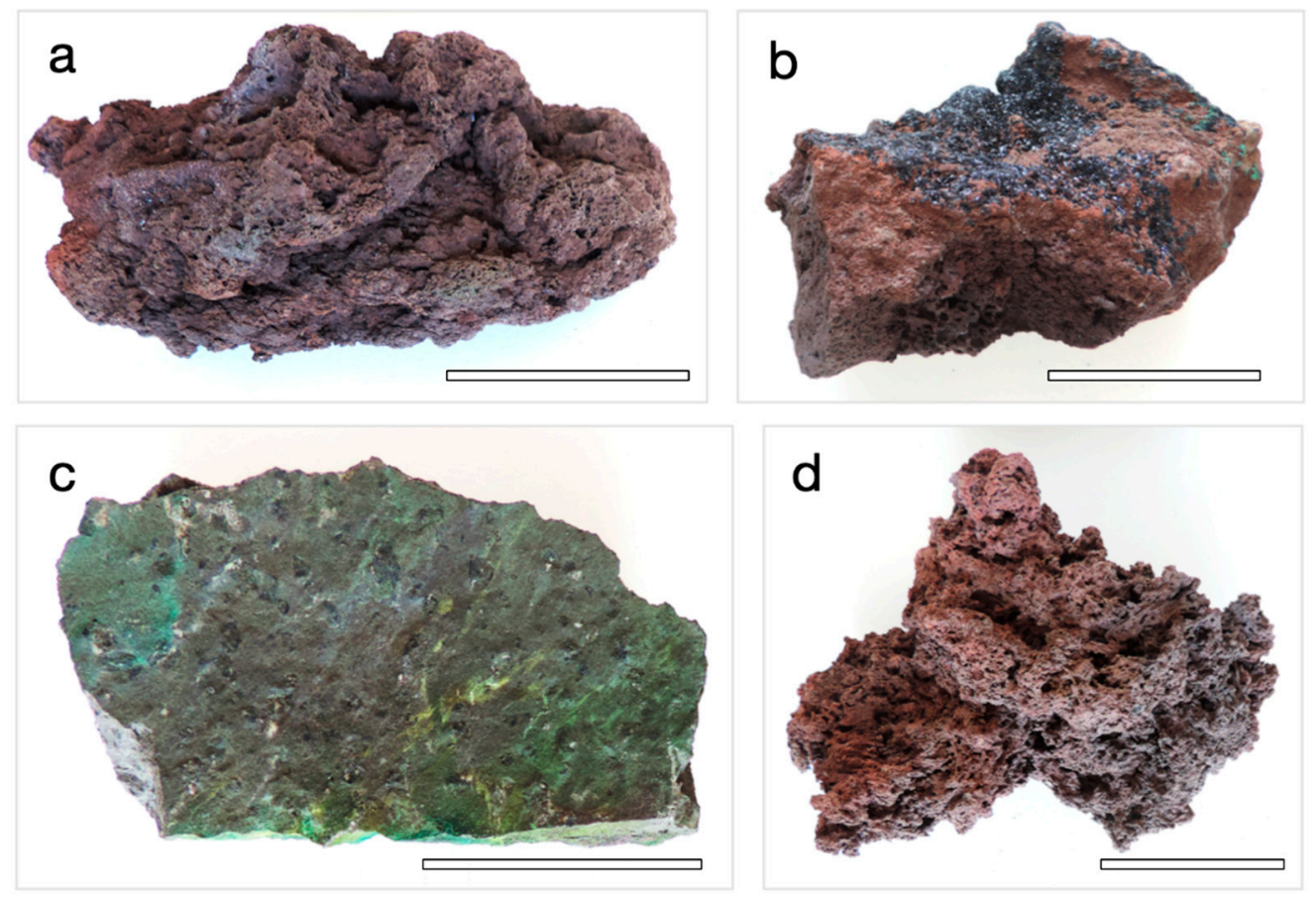

Figure 3. Macrophotos of selected copper oxides-bearing Somma-Vesuvius samples: (a) tenorite, finely disseminated on the lava surface, sample 12020 E559; (b) tenorite in well-crystallized encrustations, sample $12912 \mathrm{E} 6095$; (c) cuprite, in octahedral crystals (dark-brownish areas) on the lava host, associated with atacamite and volborthite, sample 18531 E7062; (d) microcrystalline tenorite on lava, sample 21836. The scale bar is $5 \mathrm{~cm}$.

Cuprite forms euhedral octahedrons (maximum dimension ca. $0.1 \mathrm{~mm}$ ) covering the lava surface of sample 18531 E7062 (Figure 4a,b); its composition is quite stoichiometric, with only trace amounts of Fe, Mg and Mn (Table 6). At SEM scale, tenorite generally occurs in platy to scaly individuals (Figure 4c,d); it is found as vug/surface fillings and also together with paratacamite (Figure 4e,f). 

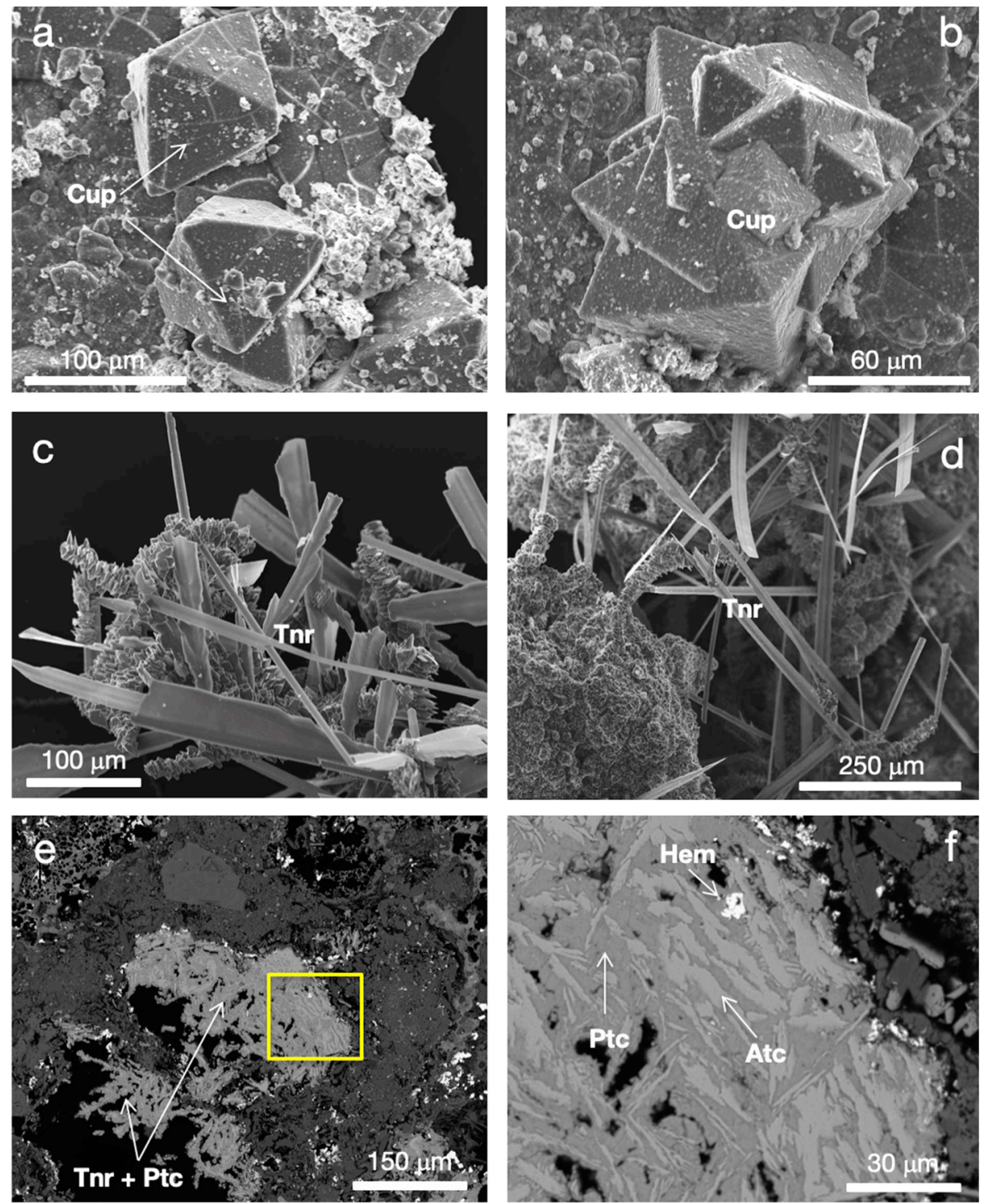

Figure 4. Cu-bearing oxides of the studied samples: (a,b) SEM images of cuprite (Cup) octahedra in sample 18531 E7062; (c,d) SEM images of lathlike crystals of tenorite (Tnr) in sample 12020 E559; (e) BSE image of lava sample $16256 \mathrm{E} 6787$, with cavities filled by the association tenorite and paratacamite (Ptc) (polished section); (f) magnification of the area in the yellow frame of (e), with paratacamite (dark grey) growing on tenorite (light grey), and hematite (Hem).

The tenorite composition is presented in Table 6 and, as for cuprite, it is fairly stoichiometric, with minor amounts of $\mathrm{Fe}, \mathrm{Mg}, \mathrm{Mn}$ and $\mathrm{Zn}$.

Table 6. Representative results of SEM-EDS analyses of cuprite and tenorite from Somma-Vesuvius.

\begin{tabular}{cccccccccc}
\hline Sample ID & \multicolumn{4}{c}{ 18531 E7062 } & \multicolumn{4}{c}{ 16256 E6787 } \\
\hline $\mathrm{wt} \%$ & \multicolumn{4}{c}{ cuprite } & \multicolumn{4}{c}{ tenorite } \\
$\mathrm{CuO}$ & 99.06 & 99.12 & 98.98 & 99.16 & 98.12 & 98.78 & 98.47 & 99.18 \\
$\mathrm{FeO}$ & 0.13 & 0.34 & 0.26 & 0.11 & - & 0.23 & 0.55 & - \\
$\mathrm{MgO}$ & - & 0.11 & & 0.07 & - & - & - & 0.34 \\
$\mathrm{MnO}$ & - & 0.10 & 0.15 & 0.06 & - & - & 0.44 & - \\
$\mathrm{ZnO}$ & - & - & - & - & 0.34 & - & - & - \\
$\mathrm{SiO}$ & - & - & - & - & - & 0.26 & - & - \\
$\mathrm{Total}$ & 99.19 & 99.67 & 99.39 & 99.40 & 98.46 & 99.27 & 99.46 & 99.52 \\
\hline
\end{tabular}

- below detection limit. 


\subsubsection{Carbonates}

Azurite was recognized in two samples, labeled as "Azurite in 1631 lavas" in the Museum catalog (Tables 2 and 3). It characteristically occurs as thin patinas on lava host with a deep blue color (Figure 5) and always associated with atacamite (Table 4 ).
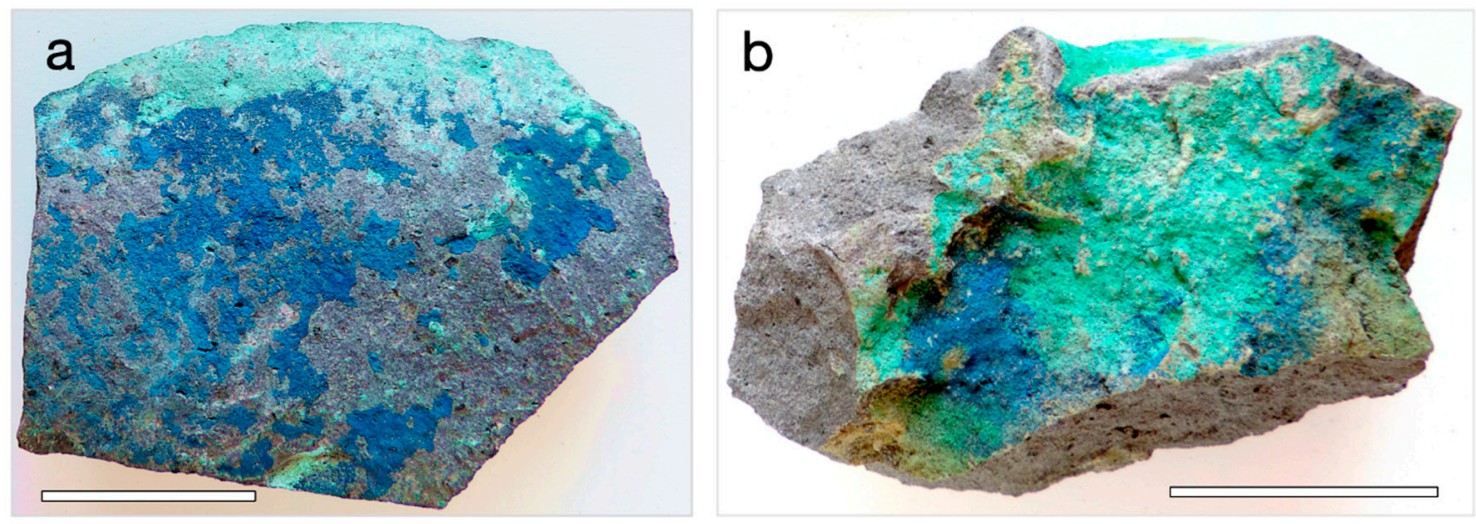

Figure 5. (a) Azurite (blue) with atacamite and subordinated malachite, sample 10817 D1268; (b) azurite (blue), with atacamite and chrysocolla, sample 10820 D1271. The scale bar is $5 \mathrm{~cm}$.

Observed at SEM, azurite shows distinctly fibrous fine-grained forms (Figure 6a,b,d) or occurs as compact admixtures with atacamite (Figure $6 \mathrm{c}$ ). Table 7 presents compositional data of azurite, which commonly shows small $\mathrm{Zn}$ concentrations $(0.18-0.82 \mathrm{wt} \% \mathrm{ZnO})$. Malachite was found only in one sample (Table 4 ) and restricted to a single area (Figure $6 \mathrm{~d}$ ).
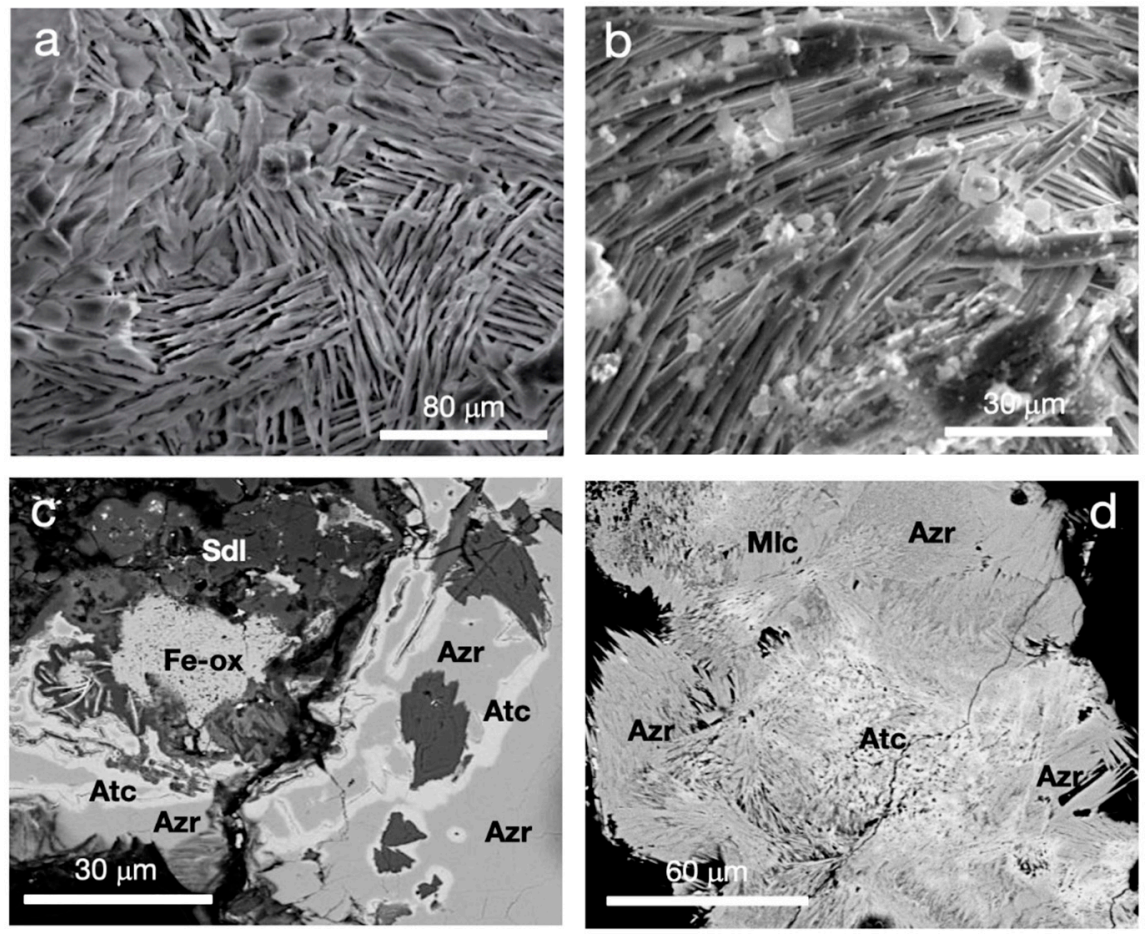

Figure 6. Cu-bearing carbonates in the Somma-Vesuvius samples (this study). (a,b) SEM image of typical fibrous, fine-grained aggregates of azurite in sample 10817 D1268 and 10820 D1271, respectively; (c) BSE image of massive azurite, with atacamite (polished section, sample 10820 D1271); (d) BSE image of fibrous crystals of azurite, with atacamite and subordinate malachite (polished section, sample 10817 D1268). 
Table 7 shows the malachite composition, characterized by a high $\mathrm{Zn}$ amount (ca. $7.4 \mathrm{wt} \%$ $\mathrm{ZnO}$ ). Even though this copper carbonate was identified in a very limited area of one sample, the chemical compositions (see Table 7) coupled to (weak) XRD reflections at 3.87 and $2.70 \AA$ are consistent with malachite.

Table 7. Representative chemical compositions of azurite and malachite from Somma-Vesuvius.

\begin{tabular}{ccccccccc}
\hline Sample ID & \multicolumn{3}{c}{$\mathbf{1 0 8 1 7}$ D1268 } & \multicolumn{3}{c}{$\mathbf{1 0 8 2 0}$ D1271 } & $\mathbf{1 0 8 1 7} \mathbf{D 1 2 6 8}$ \\
\hline $\mathrm{wt} \%$ & \multicolumn{9}{c}{ azurite } \\
$\mathrm{CuO}$ & 68.59 & 68.43 & 68.13 & 66.15 & 66.77 & 68.99 & Malachite * \\
$\mathrm{FeO}$ & - & - & 0.07 & - & - & 0.32 & 0.23 \\
$\mathrm{MgO}$ & - & - & 0.07 & - & - & - & 0.24 \\
$\mathrm{MnO}$ & - & - & - & 0.13 & - & - & - \\
$\mathrm{ZnO}$ & 0.49 & 0.36 & 0.18 & - & 0.29 & 0.82 & 7.37 \\
$\mathrm{CaO}$ & - & - & - & 0.42 & - & - & - \\
$\mathrm{Total}$ & 69.08 & 68.80 & 68.45 & 66.28 & 67.06 & 70.13 & 81.30 \\
\hline
\end{tabular}

- below detection limit. * Average of three point-analyses.

\subsubsection{Sulfates}

$\mathrm{Cu}$-bearing sulfates are the most abundant species identified in the investigated samples. These minerals generally occur in complex associations in extremely heterogeneous samples. However, at least ten different cupric sulfates are recognized (Tables 3 and 4), namely brochantite, chalcanthite, chalcocyanite ("hydrocyanite"), cryptochalcite, cyanochroite, euchlorine, kröhnkite, leightonite, linarite and natrochalcite. Some representative rock lithotypes with $\mathrm{Cu}$-bearing sulfates are shown in Figure 7.

Brochantite was detected only in sample 16256 E6768 (Table 4), where it occurs in small anhedral masses with linarite (Figures 8a and 9c). Small amounts of $\mathrm{Zn}(\mathrm{ca} .1 \mathrm{wt} \% \mathrm{ZnO}$ ) were found (Table 8).

Chalcanthite was found in three samples (Tables 3 and 4); SEM observations show subhedral crystals (Figure 8b), stoichiometric and with only traces of Fe, Mg, Mn and Ca (Table 8).

Chalcocyanite was observed in anhedral masses (Figure 8c) in three samples (Tables 3 and 4); as for chalcanthite, this sulfate only shows trace amounts of $\mathrm{Fe}, \mathrm{Mg}, \mathrm{Mn}, \mathrm{Zn}$ and $\mathrm{Ca}$ (Table 8). Cryptochalcite, occurring in three samples (Table 4), forms subhedral individuals and was found as filling of open spaces and covering external surfaces (Figure 8d). In composition, it always shows significant $\mathrm{Zn}$ amounts, in the range $1.42-3.73 \mathrm{wt} \% \mathrm{ZnO}$ (Table 8 ), as normally reported for this mineral in the literature [48,49].

Cyanochroite was found in sample 21911 only (Table 4), where forms tiny aggregates of euhedral crystals (Figure 8e) with an almost stoichiometric composition (Table 8).

Euchlorine was identified in three samples, two of which labelled as euchlorine-rich in the Museum catalog (Tables 2 and 4). This mineral occurs in quite compact masses or in euhedral crystals (Figure 8f). 

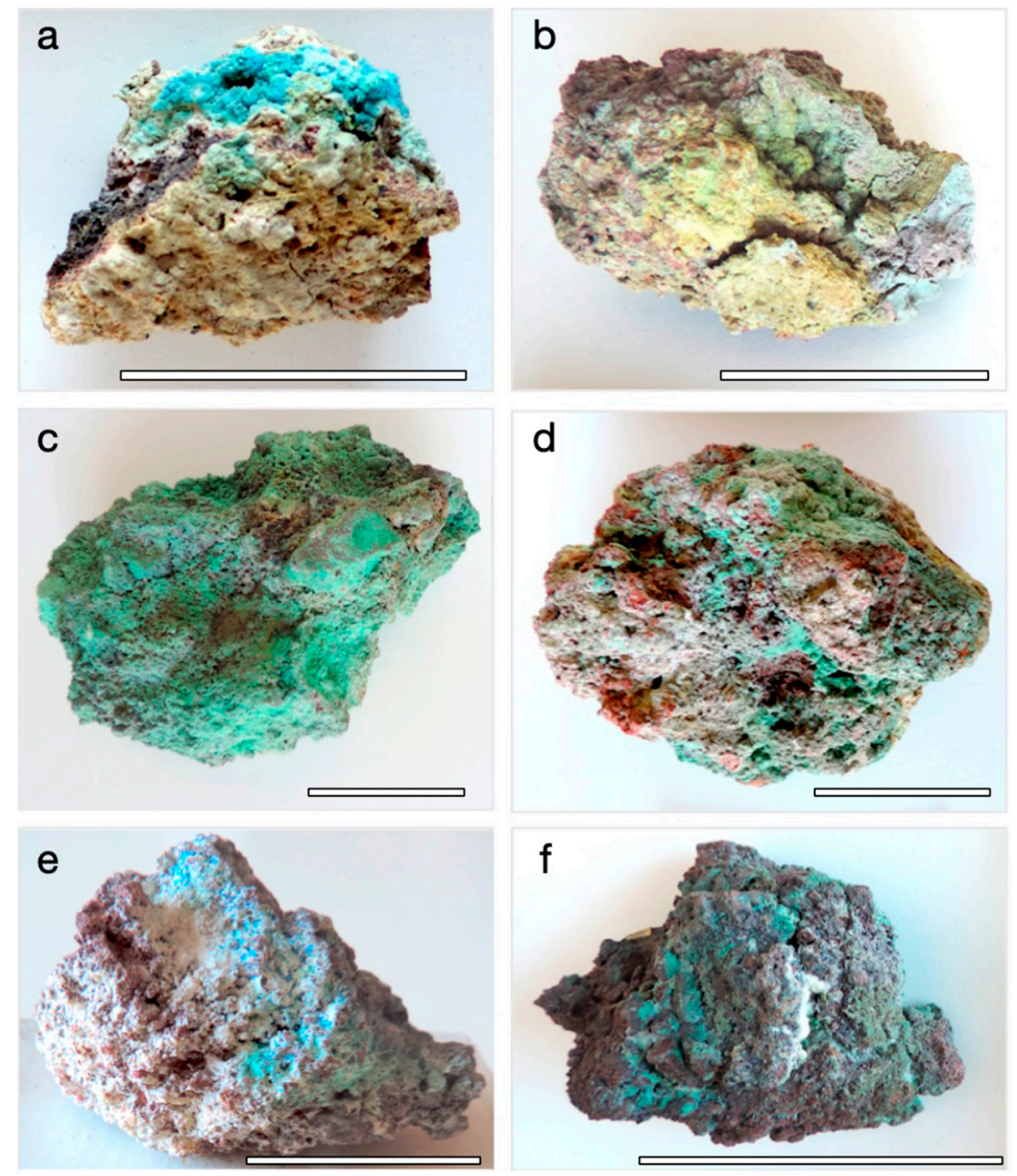

Figure 7. Macrophotos of selected Somma-Vesuvius samples with Cu-bearing sulfates. (a) Chalcanthite, leightonite and likely kröhnkite (blue fraction), sample 10741 D1192; (b) chalcocyanite and euchlorine (yellow-green fraction), sample 10907 D1358; (c) leightonite (green subsample), sample 11004, D1455; (d) cryptochalcite and kröhnkite (green fraction), sample 11269 D1720; (e) linarite (blue fraction), 16256 E6787; (f) sample 17029 E5568, classified as chlorothionite-rich in the Museum catalogs (see text for details). The scale bar is $5 \mathrm{~cm}$. 

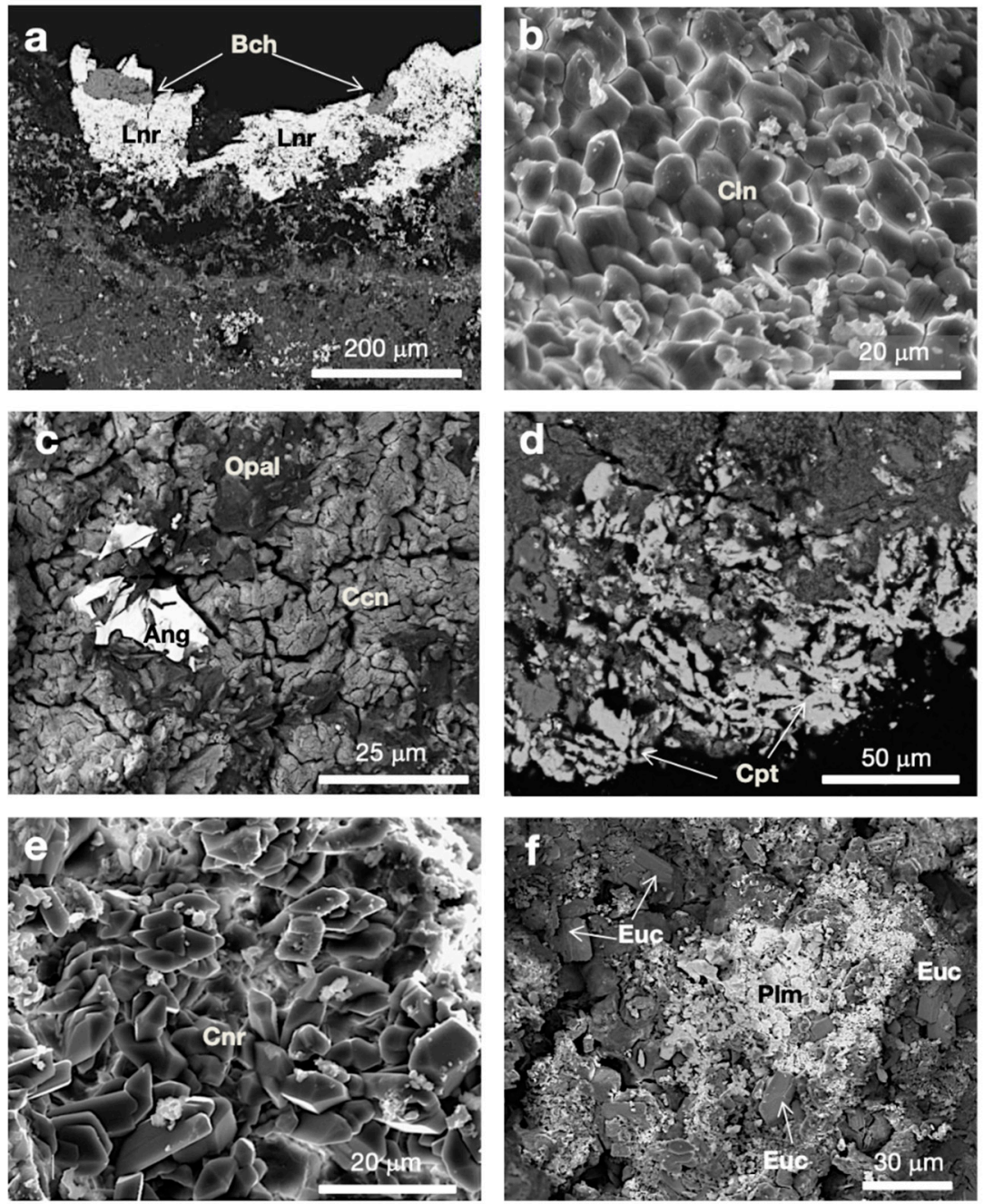

Figure 8. Cu-bearing sulfates in the Somma-Vesuvius samples from this study. (a) BSE image of brochantite (Bch) on linarite (Lnr), bordering the lava host, polished section, sample 16256 E6768; (b) SEM micrograph of chalcantite (Cln) in tiny subeuhedral crystals, sample 10741 D1192; (c) BSE micrograph of chalcocyanite (Ccn) with anglesite (Ang) and opal, sample 10907 D1358; (d) BSE image of cryptochalcite (Cpt) bordering the hosting lava, with tiny anglesite crystals (white spots), polished section, sample 11296 D1720); (e) SEM micrograph of cyanochroite (Cnr), sample 21911; (f) BSE image of euchlorine crystals (Euc) with palmierite (Plm) (sample 12912 E1457). 

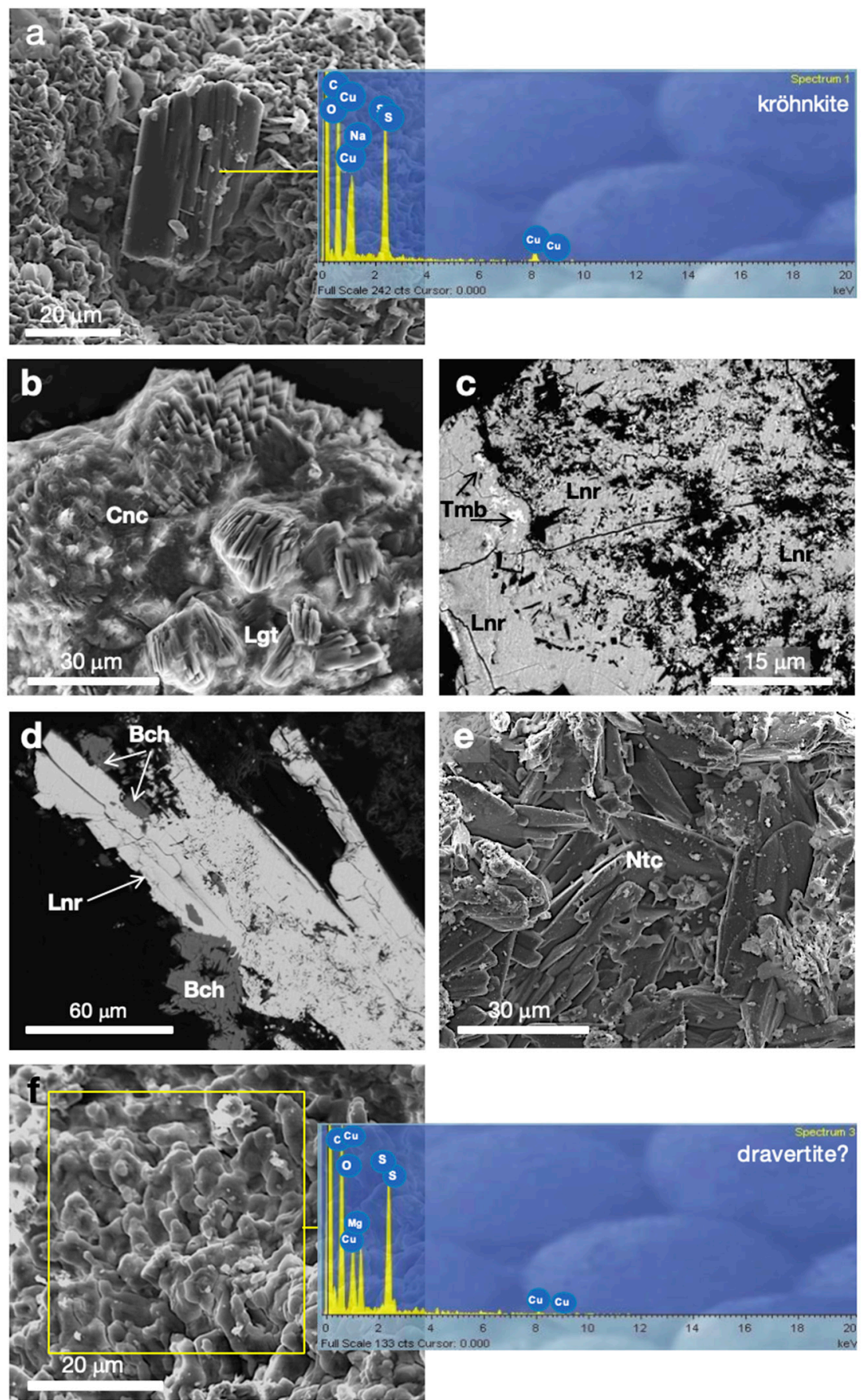

Figure 9. Cu-bearing sulfates in the studied Somma-Vesuvius samples. (a) SEM micrograph of a kröhnkite crystal on tenorite, with the related EDS spectrum, sample 11269 D1720; (b) SEM micrograph of leightonite (Lgt) and cyanochroite (Cnc) in sample 21911; (c) BSE image of linarite (Lnr) and tsumebite (Tmb) as vugs filling, sample 16256 E6787 (polished section); (d) BSE image of well crystallized linarite with minor brochantite (Bcr), sample 16256 E6787 (polished section); (e) SEM micrograph of euhedral natrochalcite (Ntc), 12912 E1457; (f) SEM micrograph of a tiny crystalline aggregate interpreted as possible dravertite, with the related EDS spectrum (sample 12756 E1295). 
Table 8. Representative chemical composition of Cu-bearing sulfates from Somma-Vesuvius: brochantite, chalcanthite, chalcocyanite, cryptochalcite, cyanochroite and euchlorine.

\begin{tabular}{|c|c|c|c|c|c|c|c|c|c|c|c|c|}
\hline Sample ID & \multicolumn{2}{|c|}{11269 D1720 } & $5357 \mathrm{I}$ & 2192 & \multicolumn{2}{|c|}{21911} & \multicolumn{4}{|c|}{16256 E6787 } & \multicolumn{2}{|c|}{5357 B2192 } \\
\hline$w t \%$ & kröl & kite & & leigh & nite & & & $\operatorname{lin}$ & ite & & natro & alcite \\
\hline $\mathrm{CuO}$ & 19.93 & 18.52 & 12.32 & 11.68 & 11.68 & 12.03 & 21.19 & 22.03 & 20.98 & 20.03 & 42.62 & 43.37 \\
\hline $\mathrm{FeO}$ & 0.45 & & 0.04 & 0.36 & 0.98 & 1.40 & 0.55 & - & - & - & 0.08 & 0.09 \\
\hline $\mathrm{MgO}$ & 0.23 & 0.11 & 0.07 & 0.11 & 0.38 & 0.44 & - & - & - & - & 0.77 & 0.13 \\
\hline $\mathrm{MnO}$ & 0.08 & & - & 0.09 & - & - & - & - & - & - & - & 0.07 \\
\hline $\mathrm{ZnO}$ & & & - & - & - & - & - & 0.37 & - & 0.68 & - & 0.11 \\
\hline $\mathrm{CaO}$ & 0.05 & 0.12 & 18.13 & 17.64 & 16.18 & 17.99 & - & - & - & - & - & - \\
\hline $\mathrm{Na}_{2} \mathrm{O}$ & 19.07 & 18.28 & 0.55 & 0.47 & 0.75 & 0.43 & - & - & - & - & 6.79 & 6.68 \\
\hline $\mathrm{K}_{2} \mathrm{O}$ & 0.22 & & 14.03 & 13.31 & 12.39 & 13.86 & - & - & - & - & - & 0.12 \\
\hline $\mathrm{PbO}$ & & & - & 0.09 & - & - & 0.11 & - & - & 0.09 & - & - \\
\hline $\mathrm{As}_{2} \mathrm{O}_{5}$ & & & - & - & - & - & - & - & - & - & - & - \\
\hline $\mathrm{P}_{2} \mathrm{O}_{5}$ & & & - & - & - & - & 55.43 & 53.51 & 53.33 & 57.41 & - & - \\
\hline $\mathrm{SO}_{3}$ & 46.99 & 47.34 & 48.94 & 49.04 & 49.71 & 49.63 & 19.63 & 18.41 & 18.65 & 17.62 & 43.48 & 43.44 \\
\hline Total & 87.02 & 84.37 & 94.084 & 92.79 & 92.07 & 95.78 & 96.91 & 94.32 & 92.95 & 95.83 & 93.74 & 94.01 \\
\hline
\end{tabular}

Kröhnkite was likely detected in sample 11269 D1720, where crystals with short prismatic habits are observed (Figure 9a); small but distinct XRD reflections at ca. 6.34 and $3.29 \AA$, typical of this phase, are recognized, whereas the composition shows minor contents of $\mathrm{Fe}, \mathrm{Mg}, \mathrm{Mn}, \mathrm{Na}$ and $\mathrm{Ca}$ (Table 9).

Kröhnkite can be possibly present in other four samples, for which only qualitative EDS spectra could be obtained, hence, its occurrence needs further validation (Table 4).

Leightonite, observed in three samples (Table 4), is represented by crystals with a platy habit (Figure $9 b$ ) and a nearly stoichiometric composition (Table 9).

Linarite and natrochalcite are both recognized in two samples (Table 4); linarite forms acicular individuals or microcrystalline encrustations (Figure $9 b, c$ ) and is chemically nearly pure (Table 9 ). Natrochalcite was observed in sharp bipyramidal crystal (Figure 9e); as for linarite, its composition is almost stoichiometric (Table 9).

According to the historic Museum classification, two $\mathrm{Cu}$-bearing sulfates, i.e., boothite (corresponding to the discredited "cupromagnesite") and chlorothionite, had to be present in samples 11004 D1455 and 17032 E5571 ("cupromagnesite") and 17029 E5568 and 17030 E5569 (chlorothionite), (Table 2). However, these sulfates were not surely identified (at least in the subsamples selected for this study), because in the XRD patterns, the diagnostic reflections were very weak ( $3.02 \AA$ for boothite in sample 17032 E5571, and 3.02 Å for chlorothionite in samples 17029 E5568 and 17030 E5569), and at the same time, it was not possible to obtain good-quality quantitative chemical analyses, but only some EDS qualitative spectra (Table 4).

Finally, dravertite, a rare $\mathrm{Cu}-\mathrm{Mg}$ bearing sulfate of recent discovery [50], could likely occur in sample 12756 E1295, even though only qualitative EDS spectra were obtained in a very limited area (Figure 9f) and a weak reflection at $2.65 \AA$ was found in the XRD pattern of a multimineralic sample, affected by many reflections overlappings. 
Table 9. Representative chemical composition of Cu-bearing sulfates from Somma-Vesuvius: kröhnkite, leightonite, linarite and natrochalcite.

\begin{tabular}{|c|c|c|c|c|c|c|c|c|c|c|c|c|c|c|c|c|}
\hline \multirow{3}{*}{$\begin{array}{c}\text { Sample ID } \\
\text { oxide wt } \% \\
\mathrm{CuO}\end{array}$} & \multicolumn{2}{|c|}{16256 E6787 } & \multicolumn{2}{|c|}{10741 D1192 } & \multicolumn{2}{|c|}{10907 D1358 } & \multicolumn{2}{|c|}{5357 В2192 } & \multicolumn{2}{|c|}{11296 D1720 } & \multicolumn{2}{|c|}{12756 E1295 } & \multicolumn{2}{|c|}{21911} & \multicolumn{2}{|c|}{12912 E1457 } \\
\hline & broch & antite & chalca & nthite & chalco & yanite & & & crypto & chalcite & & & cyano & hroite & euch & orine \\
\hline & 72.13 & 71.04 & 32.08 & 31.44 & 48.88 & 47.93 & 42.38 & 43.82 & 42.51 & 42.51 & 46.09 & 46.37 & 20.22 & 19.97 & 42.86 & 41.09 \\
\hline $\mathrm{FeO}$ & - & 0.55 & - & 0.15 & 0.24 & - & 0.27 & 0.27 & - & 0.24 & - & - & - & 0.67 & 0.78 & 0.22 \\
\hline $\mathrm{MgO}$ & - & - & 0.13 & 0.06 & 0.65 & 0.06 & - & 0.09 & 0.96 & - & - & - & - & 0.56 & - & 0.21 \\
\hline $\mathrm{MnO}$ & 0.33 & - & - & 0.07 & 0.11 & - & 0.12 & - & - & - & - & - & 0.23 & - & - & - \\
\hline $\mathrm{ZnO}$ & 1.08 & 0.97 & - & - & 0.09 & 0.09 & 1.55 & 1.42 & 1.83 & 1.71 & 3.74 & 3.15 & - & - & 0.56 & - \\
\hline $\mathrm{Na}_{2} \mathrm{O}$ & - & - & - & - & - & - & - & - & - & - & - & - & - & - & 6.00 & 5.72 \\
\hline $\mathrm{K}_{2} \mathrm{O}$ & - & - & - & - & - & - & 9.63 & 9.63 & 11.24 & 9.64 & 9.93 & 8.44 & 22.34 & 21.78 & 6.99 & 7.99 \\
\hline $\mathrm{CaO}$ & - & - & 0.50 & - & - & 0.22 & 0.02 & 0.01 & - & - & - & - & - & 0.05 & - & 0.99 \\
\hline $\mathrm{SO}_{3}$ & 18.02 & 17.68 & 33.17 & 34.09 & 49.06 & 50.05 & 44.83 & 44.82 & 42.90 & 45.48 & 40.55 & 42.58 & 35.87 & 35.33 & 41.90 & 42.67 \\
\hline Total & 91.56 & 90.24 & 65.88 & 65.81 & 99.03 & 98.35 & 98.81 & 100.06 & 99.44 & 99.58 & 100.31 & 100.54 & 78.66 & 78.36 & 99.09 & 98.89 \\
\hline
\end{tabular}

- below detection limit. 


\subsubsection{Vanadates}

The cupric vanadates are found in sample 18531 E7062 labelled as "cuprite" and in the samples with the discredited "vesbine", as expected [10,51], i.e., 17718 E6249, 17719 E6250 and 17722 E6253 (Tables 2 and 4, Figures 1e, 3c and 10).
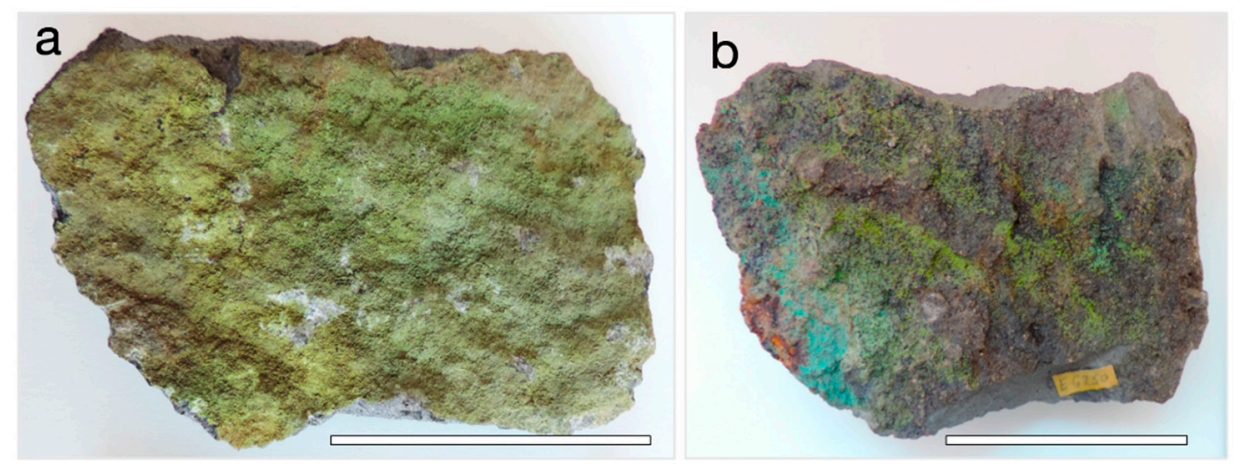

Figure 10. The Cu-bearing vanadates, concentrated in the light green-yellowish parts in association with other copper minerals (see text) in the samples (a) 17718 E6249 and (b) 17719 E6250. The scale bar is $5 \mathrm{~cm}$.

Volborthite was only detected in sample 18531 E7062 (Figure 3c), where it forms a tiny light green-yellowish patina close to atacamite efflorescences; at SEM scale, it occurs in platy crystals of maximum ca. $10 \mu \mathrm{m}$ in length (Figure 11a). The chemical composition of this mineral is given in Table 10 and shows trace amounts of Fe, Mg, Mn, Zn and P (respectively, up to 0.33, 0.23, 0.26, 0.09 and $0.11 \mathrm{wt} \%$ in oxides).

In the investigated samples 17718 E6249, 17719 E6250 and 17722 E6253, the so-called "vesbine"-rich fraction is mainly formed by tiny concretions (Figure $11 \mathrm{~b}-\mathrm{e}$ ) composed of mottramite, the $\mathrm{Cu}-\mathrm{Pb}$-bearing vanadate, and chrysocolla plus vanadinite (see the following Section 4.2). These copper minerals form rounded to botryoidal-like masses (Figure 11b), that in polished sections correspond to a texture with a distinct colloform growth banding (Figure 11c-e). The mottramite composition (Table 10) shows significant amounts of As (1.55-2.74 $\left.\mathrm{wt}^{\mathrm{o}} \mathrm{As}_{2} \mathrm{O}_{5}\right)$, and variable contents of $\mathrm{Fe}, \mathrm{Mg}, \mathrm{Mn}, \mathrm{Zn}, \mathrm{Al}$ and $\mathrm{Ca}$.

In sample 17722 E6253, together with the above-mentioned minerals, starovaite, a rare $\mathrm{Cu}-\mathrm{K}$-bearing vanadate of recent discovery [52], was also found (Tables 3 and 4). This mineral shows tiny crystals (maximum dimension ca. $4 \mu \mathrm{m}$ in length) with an euhedral prismatic habit (Figure 11f,g); it occurs mainly in association with chrysocolla. Its chemical composition is very similar to the species found in the literature [52], with small contents of Mn and Zn (Table 10). However, the identification of starovaite was made by EDS only, as its characteristic reflections were not detected in the XRD patterns, due to the low amounts of this mineral in the sample.

Lastly, tsumebite (Tables 3 and 4) was detected in sample 16256 E6787, as cavity filling in elpasolite-rich matrix (Figure 11h). Its composition is given in Table 10. However, as for starovaite, tsumebite was characterized only by EDS analyses, but it was not possible to recognize its occurrence in the XRD spectrum, due to scarce amounts of this mineral. 

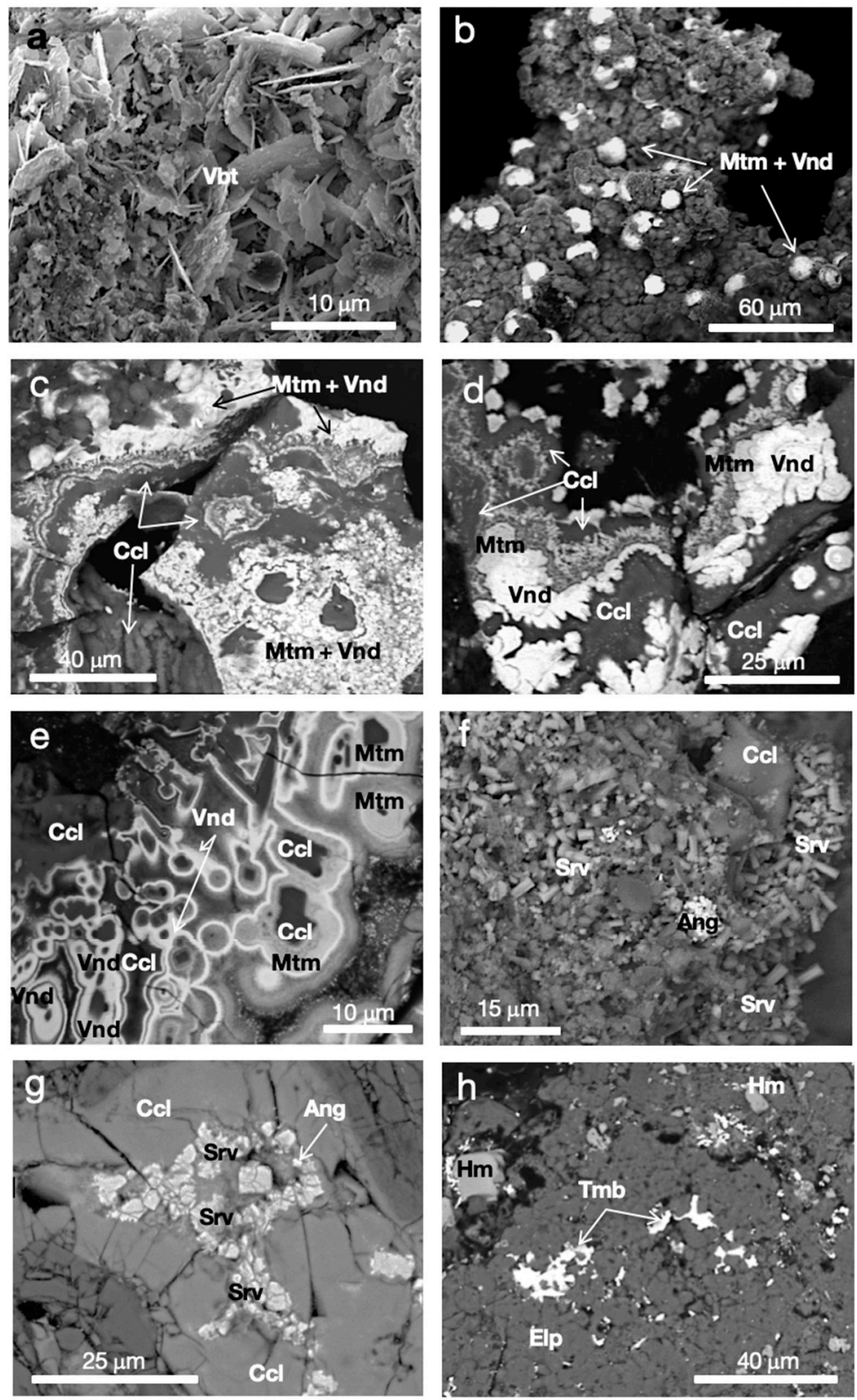

Figure 11. Copper vanadates and phosphates in the studied samples. (a) SEM micrograph of scaly crystals of volborthite, sample 18531 E7062; (b) BSE micrograph of white spherules composed of mottramite (Mtm) and vanadinite (Vnd) in a silicate matrix (likely chrysocolla-prevailing), sample 17718 E6249; (c) BSE micrograph of cockade concretions formed by vanadinite (white), mottramite (medium grey) and chrysocolla (Ccl) (dark grey), sample 17718 E6249; (d) BSE image of zoned concretions composed of mottramite and vanadinite (white parts) and chrysocolla (grey parts), sample 17719 E6250 (polished section); (e) another area of sample 17719 E6250 (BSE image) with a distinct zonation of the Pb $\pm \mathrm{Cu}$ vanadates and the $\mathrm{Cu}$-bearing silicate (polished section); (f), SEM images of euhedral prismatic crystal of starovaite (Srv), associated with chrysocolla and minor anglesite (Ang), sample 17722 E6252; (g) BSE (polished section) image of sample 17722 E6252, showing anhedral aggregates of starovaite (light grey), with chrysocolla and anglesite, sample 17722 E6252 (see text for further details); (h) BSE image of tsumebite (Tmb) as vugs filling among elpasolite (Eps), with few crystals of hematite (Hm), sample 16256 E6787 (polished section). 
Table 10. Chemical compositions of the selected $\mathrm{Cu}$-bearing vanadates and phosphates from Somma-Vesuvius.

\begin{tabular}{|c|c|c|c|c|c|c|c|c|c|c|c|c|c|c|c|c|c|}
\hline \multirow{3}{*}{$\begin{array}{c}\text { Sample ID } \\
\text { oxide } w t \% \\
\mathrm{CuO}\end{array}$} & \multicolumn{2}{|c|}{18531 E7062 } & \multicolumn{3}{|c|}{17718 E6249 } & \multicolumn{5}{|c|}{17719 E6250 } & \multicolumn{5}{|c|}{17722 E6253 } & \multicolumn{2}{|c|}{16256 E6787 } \\
\hline & volbo & thite & & & & mott & amite & & & & & & tarovai & & & tsum & ebite \\
\hline & 51.24 & 50.97 & 18.03 & 19.86 & 20.81 & 18.89 & 24.00 & 21.50 & 21.75 & 20.87 & 49.70 & 49.46 & 49.88 & 50.89 & 49.88 & 12.09 & 13.93 \\
\hline $\mathrm{FeO}$ & 0.25 & 0.33 & 1.39 & 2.97 & 1.09 & 2.03 & - & - & - & - & - & - & - & - & - & - & 0.14 \\
\hline $\mathrm{MgO}$ & - & 0.23 & - & - & 0.76 & - & - & - & - & - & - & - & - & - & - & 0.12 & - \\
\hline $\mathrm{MnO}$ & 0.12 & 0.26 & - & 1.55 & - & 1.67 & - & - & - & - & 1.26 & 1.00 & - & - & 2.73 & - & - \\
\hline $\mathrm{ZnO}$ & - & 0.09 & 0.78 & 1.10 & 3.19 & - & - & - & - & - & 0.14 & - & 0.56 & 0.44 & - & 0.47 & 0.32 \\
\hline $\mathrm{Al}_{2} \mathrm{O}_{3}$ & - & - & 0.81 & 1.53 & - & 1.87 & - & - & 1.01 & 0.94 & - & - & - & - & - & - & - \\
\hline $\mathrm{K}_{2} \mathrm{O}$ & - & - & - & - & - & - & - & - & - & - & 7.12 & 7.24 & 7.43 & 8.11 & 7.82 & - & - \\
\hline $\mathrm{CaO}$ & - & - & 1.62 & 2.22 & 0.89 & - & 1.17 & - & - & - & - & - & - & - & - & - & 0.07 \\
\hline $\mathrm{PbO}$ & - & - & 51.40 & 49.15 & 53.97 & 51.37 & 49.93 & 49.87 & 48.93 & 50.66 & - & - & - & - & - & 62.41 & 63.07 \\
\hline $\mathrm{V}_{2} \mathrm{O}_{5}$ & 39.06 & 38.68 & 19.32 & 17.23 & 16.09 & 18.12 & 20.63 & 22.54 & 20.99 & 20.51 & 38.71 & 39.67 & 39.62 & 39.45 & 38.56 & - & - \\
\hline $\mathrm{As}_{2} \mathrm{O}_{5}$ & - & - & 2.74 & 1.89 & 2.56 & 2.01 & 2.43 & 2.08 & 2.17 & 1.55 & - & - & - & - & - & 2.30 & 1.85 \\
\hline $\mathrm{P}_{2} \mathrm{O}_{5}$ & - & 0.11 & - & - & - & - & - & - & - & - & - & - & - & - & - & 10.76 & 8.54 \\
\hline $\mathrm{SO}_{3}$ & - & - & - & - & - & - & - & - & - & - & - & - & - & - & - & 11.00 & 10.46 \\
\hline $\mathrm{Cl}$ & - & - & - & - & - & - & - & - & - & - & 0.51 & 0.63 & 0.69 & 1.05 & 0.57 & - & - \\
\hline$-\mathrm{Cl}_{2}=\mathrm{O}$ & & & & & & & & & & & 0.11 & 0.14 & 0.16 & 0.24 & 0.13 & & \\
\hline Total & 90.67 & 90.67 & 96.09 & 97.50 & 99.36 & 95.96 & 98.16 & 95.98 & 94.84 & 94.52 & 97.55 & 98.14 & 98.34 & 100.18 & 99.69 & 99.15 & 98.38 \\
\hline
\end{tabular}

- below detection limit. 


\subsubsection{Silicates}

The Cu-bearing silicates found in the investigated samples are chrysocolla (Figures 1e and 10) and litidionite (Figure 12).

Chrysocolla occurs mainly in efflorescences in association with the copper vanadates or atacamite, as observed in the previous sections, where it is indistinguishable to the naked eye (Figures 1e and 10); this silicate was clearly identified by SEM observations, as reported in Figures $2 b, 11 b-g$ and $13 \mathrm{a}, \mathrm{b}$, and forms few micrometer-sized zoned concretions. Table 11 shows the chemical composition of chrysocolla; it always contains some $\mathrm{Ca}$ amounts, in the range 1.0-1.8 wt $\% \mathrm{CaO}$, and variable contents of $\mathrm{Fe}, \mathrm{Mg}$, Mn, $\mathrm{K}$ and $\mathrm{Zn}$, whereas trace amounts of $\mathrm{Pb}$ and $\mathrm{V}$ can be related to vanadate impurities.
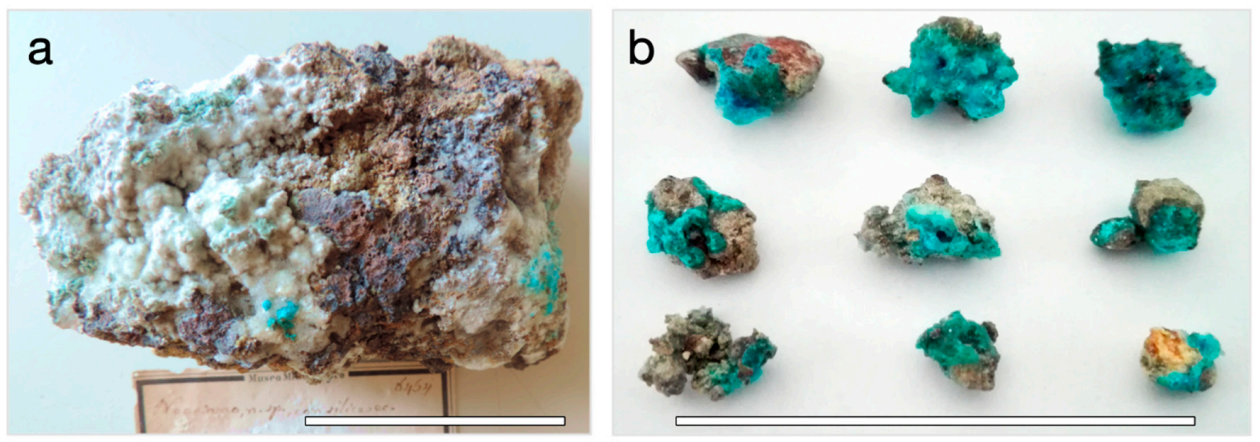

Figure 12. Litidionite (the obsolete neocyanite) in sample (a) 17923 E6454 and (b) 17926 E6457 (see text for details). The scale bar is $5 \mathrm{~cm}$.
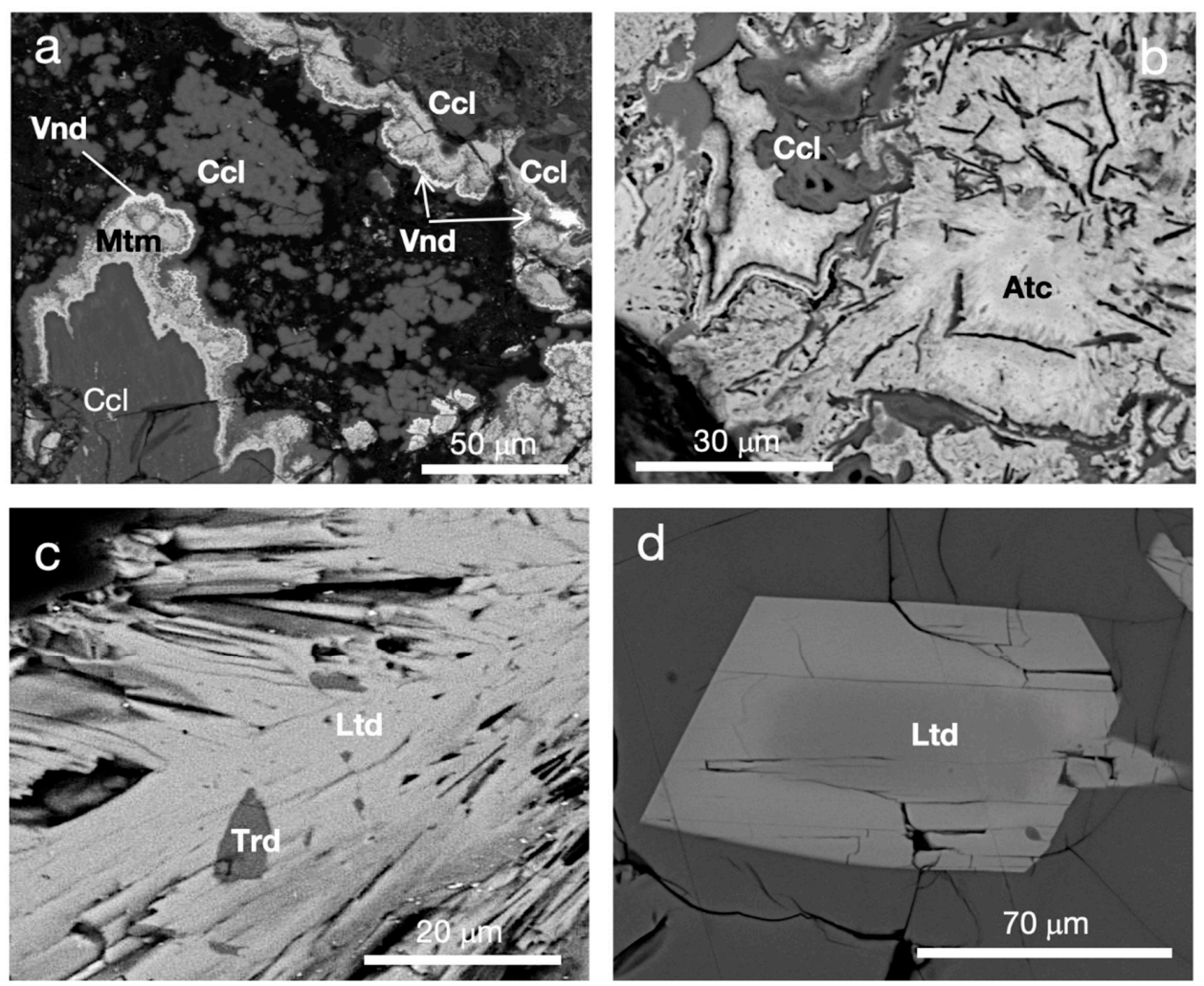

Figure 13. BSE images (polished sections) of Cu-bearing silicates from Somma-Vesuvius. (a,b) Chrysocolla $(\mathrm{Ccl})$ in strongly concretionary textures of samples 17719 E6250 and 10820 D1271, respectively, occurring with vanadinite (Vnd) and mottramite (Mtm) in the first sample, and with atacamite (Atc) in the second one; (c) litidionite (Ltd) crystal with tridymite inclusion (Trd) in sample 17923 E6465; (d) slightly zoned (Cu-poor core vs. Cu-rich rim), euhedral litidionite crystal in an amorphous silica-rich matrix (dark gray; see text), sample 17926 E6457 (see text). 
Table 11. Chemical compositions of selected Cu-bearing silicates from Somma-Vesuvius. For litidionite, the analyses labelled as 'core' and 'rim' refer to the crystal in Figure 13d (average of three point-analyses).

\begin{tabular}{|c|c|c|c|c|c|c|c|c|c|c|c|c|c|c|c|c|}
\hline \multirow{2}{*}{$\frac{\text { Sample ID }}{w^{t} \%}$} & \multicolumn{3}{|c|}{17719 E6250 } & & \multicolumn{4}{|c|}{17722 E6253 } & \multicolumn{4}{|c|}{19723 E6454 } & \multicolumn{4}{|c|}{19726 E6457 } \\
\hline & \multicolumn{8}{|c|}{ chrysocolla } & \multicolumn{8}{|c|}{ litidionite } \\
\hline $\mathrm{SiO}_{2}$ & 35.23 & 37.72 & 35.07 & 34.05 & 39.22 & 36.00 & 38.96 & 36.93 & $\begin{array}{c}\text { core } \\
59.35\end{array}$ & $\begin{array}{c}\text { rim } \\
59.81\end{array}$ & 61.68 & 62.07 & 59.81 & 60.13 & 60.51 & 58.99 \\
\hline $\mathrm{Al}_{2} \mathrm{O}_{3}$ & 5.38 & 5.21 & 6.32 & 6.22 & 4.58 & 6.41 & 5.99 & 4.86 & 0.28 & - & - & - & - & - & 0.05 & - \\
\hline $\mathrm{CuO}$ & 42.24 & 45.91 & 46.33 & 42.51 & 42.36 & 40.91 & 41.96 & 43.82 & 21.02 & 19.28 & 17.92 & 17.32 & 19.28 & 20.02 & 18.15 & 19.66 \\
\hline $\mathrm{FeO}$ & 2.11 & - & - & 1.00 & 0.77 & - & - & - & - & - & - & - & - & - & - & - \\
\hline $\mathrm{MgO}$ & 0.78 & 0.35 & - & 0.54 & - & - & - & - & 0.27 & 0.67 & - & - & 0.63 & 0.35 & - & - \\
\hline $\mathrm{MnO}$ & 1.60 & - & - & 1.19 & - & - & - & - & - & - & - & - & - & - & - & - \\
\hline $\mathrm{ZnO}$ & - & 0.66 & - & 0.22 & 0.87 & - & - & - & - & - & - & - & - & - & - & - \\
\hline $\mathrm{Na}_{2} \mathrm{O}$ & - & - & - & - & & - & - & - & 8.42 & 8.30 & 7.93 & 8.02 & 8.30 & 8.16 & 7.93 & 7.54 \\
\hline $\mathrm{K}_{2} \mathrm{O}$ & - & - & - & - & 0.47 & 1.25 & - & - & 10.41 & 10.35 & 12.05 & 11.90 & 10.35 & 10.83 & 11.28 & 12.12 \\
\hline $\mathrm{CaO}$ & 1.77 & 1.00 & - & 1.62 & 1.34 & 1.41 & 1.05 & 1.54 & 0.84 & 0.99 & 0.92 & 1.01 & 0.99 & 1.03 & 1.11 & 0.79 \\
\hline $\mathrm{PbO}$ & 0.97 & - & - & - & - & - & - & - & - & - & - & - & - & - & - & - \\
\hline $\mathrm{V}_{2} \mathrm{O}_{5}$ & 0.77 & - & - & - & - & - & - & - & - & - & - & - & - & - & - & - \\
\hline Total & 90.85 & 90.85 & 87.72 & 87.35 & 89.61 & 85.98 & 87.96 & 87.15 & 100.58 & 99.40 & 100.50 & 100.33 & 99.36 & 100.51 & 99.03 & 99.11 \\
\hline
\end{tabular}


Litidionite (neocyanite) characteristically occurs in the deep blue glassy crusts on lava fragments or small lapilli (Figure 12), deeply affected by the fumarolic activity (Table 2) [33]. In the analyzed samples (17923 E6454 and 17926 E6457), litidionite occurs with tridymite, calcinaksite, wollastonite and locally minor amorphous silica-rich phase (see Section 4.2), diopside, atacamite and halite. Observed at SEM scale, its crystal habit is fibrous, as in sample 17923 E6465 (Figure 13c), or can form euhedral and platy crystals, as in sample 17923 E6465 (Figure 13d). Table 11 shows the chemical composition of litidionite; some crystals of sample 17923 E6465 show a zonation, with higher Cu contents decreasing toward the rim (see Table 11); the compositional ranges are 58.99-62.07 $\mathrm{wt} \% \mathrm{SiO}_{2}, 17.32-21.02 \mathrm{wt} \%$ $\mathrm{CuO}, 7.54-8.42 \mathrm{wt}^{\mathrm{O}} \mathrm{Na}_{2} \mathrm{O}, 10.35-12.12 \mathrm{wt} \% \mathrm{~K}_{2} \mathrm{O}$ and $0.79-1.11 \mathrm{wt} \% \mathrm{CaO}$, with traces of $\mathrm{Mg}$ and $\mathrm{Al}$.

\subsection{Associated Minerals}

As illustrated in Table 4, a variety of minerals can be associated with the Cu-bearing phases, among which selected $\mathrm{Cu}$-free halides, sulfates, molibdates, phosphates, vanadates and silicates are reported in Figures 14 and 15 and in Table 12.
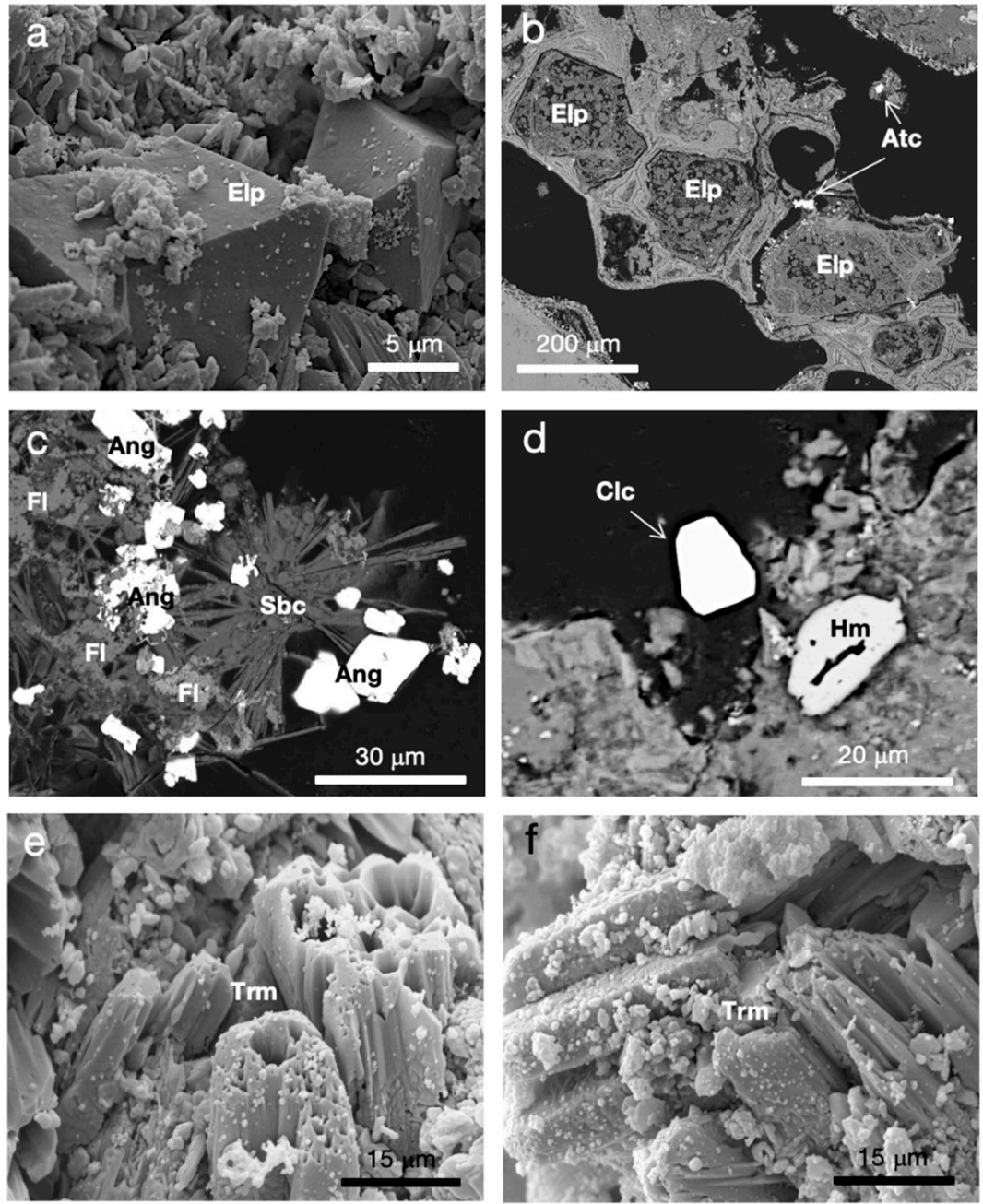

Figure 14. Various minerals associated with Cu-bearing species in the studied samples: (a) SEM micrograph of elpasolite octahedra (Elp) in a mixed sulfates matrix, sample 11269 D1729; (b) BSE image of cavities in the lava host filled by elpasolite and surrounded by thin atacamite (Atc) layers and crystals, sample 11269 D1729 (polished section); (c) BSE image of needle-shaped sbacchiite crystals (Sbc), with anglesite (Ang) and fluorite (Fl), sample 16256 E6787 (polished section); (d) euhedral crystal of challacolloite $(\mathrm{Clc})$ with hematite $(\mathrm{Hm})$ in a mixed sulfates matrix, sample 11061 D1512 (BSE image, polished section); (e,f) thermessaite (Trm) crystals, partly corroded (sample 11269 D1720). 

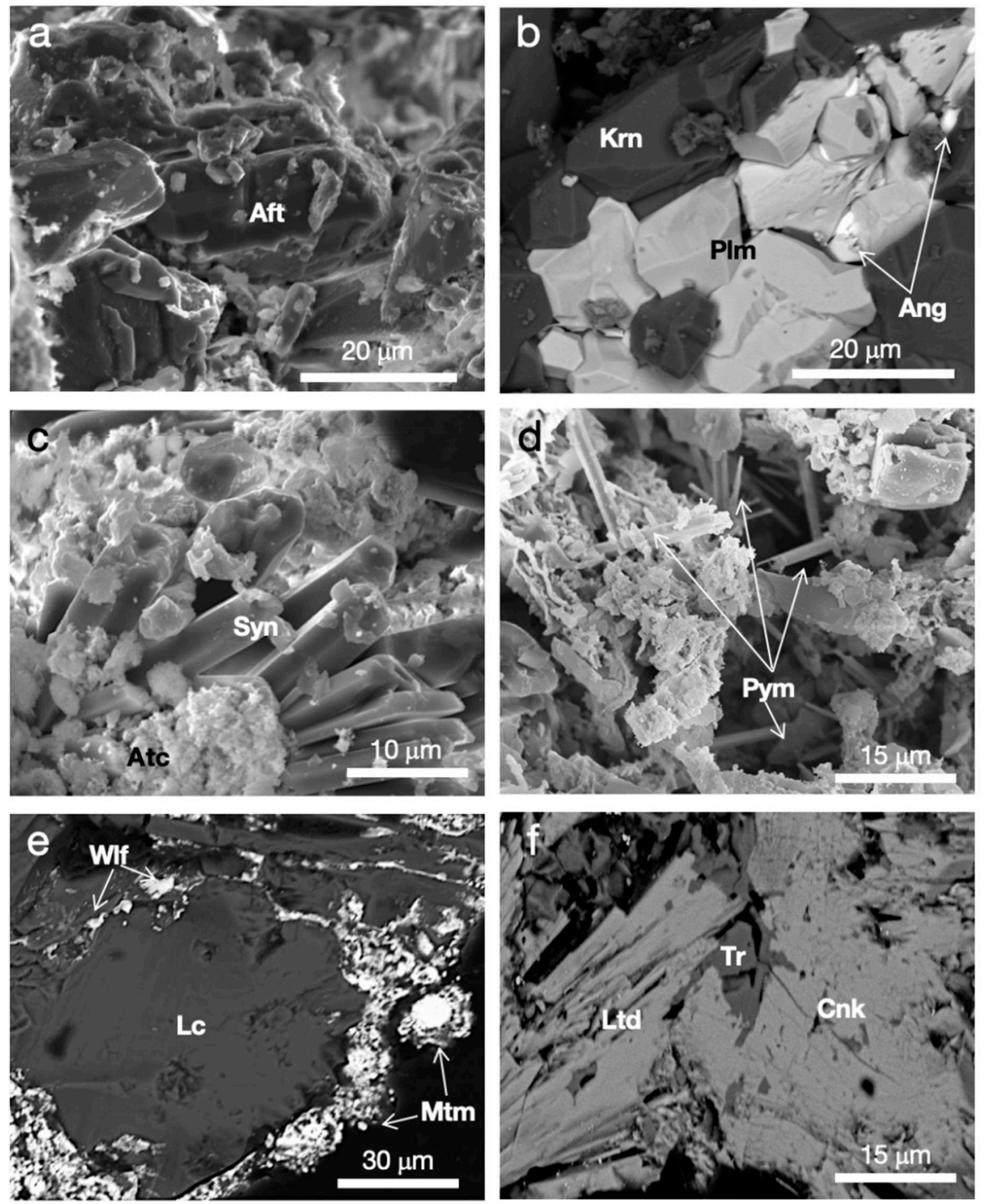

Figure 15. Various minerals associated with $\mathrm{Cu}$-bearing species in the studied samples. SEM micrographs of (a) aphthitalite crystals (Aft), sample 17030 E5569; (b) palmierite (Plm) surrounded by kröhnkite (Krn) and with anglesite inclusions, sample 11269 D1729; (c) slender prisms of syngenite (Syn) with atacamite (sample 17029 E5568); (d) pyromorphite in acicular crystals (sample 16256 E6787). BSE images (polished sections) of (e) wulfenite (Wlf) with mottramite (Mtm) around a leucite crystal (Lc) (sample 17718 E6249); (f) calcinaksite (Cnk) with litidionite (Ltd) and tridymite (Tr), sample 17923 E6465. 
Table 12. Representative chemical compositions of selected miscellaneous minerals associated with Cu-bearing minerals from Somma-Vesuvius

\begin{tabular}{|c|c|c|c|c|c|c|c|c|c|c|c|c|c|c|c|c|c|}
\hline \multirow{3}{*}{$\begin{array}{c}\text { Sample ID } \\
\text { element } w \mathrm{t} \% \\
\mathrm{Al}\end{array}$} & \multicolumn{2}{|c|}{17030 E5569 } & \multicolumn{2}{|c|}{16256 E6787 } & \multirow{2}{*}{\multicolumn{2}{|c|}{$\begin{array}{c}16256 \text { E6787 } \\
\text { sbacchiite }\end{array}$}} & \multicolumn{3}{|c|}{11061 D1512 } & \multicolumn{2}{|c|}{16256 E6787 } & \multicolumn{2}{|c|}{17030 E5569 } & \multicolumn{2}{|c|}{11269 D1720 } & \multicolumn{2}{|c|}{16256 E6787 } \\
\hline & \multicolumn{4}{|c|}{ elpasolite } & & & \multicolumn{2}{|c|}{ challacolloite } & \multirow{2}{*}{$\begin{array}{c}\mathrm{wt} \% \\
\mathrm{Al}_{2} \mathrm{O}_{3}\end{array}$} & \multicolumn{2}{|c|}{ thermessaite } & \multicolumn{2}{|c|}{ aphthitalite } & \multicolumn{2}{|c|}{ palmierite } & \multicolumn{2}{|c|}{ syngenite } \\
\hline & 11.13 & 11.07 & 11.98 & 11.71 & 11.88 & 11.54 & - & - & & 21.09 & 20.98 & - & - & - & - & - & - \\
\hline $\mathrm{Na}$ & 9.31 & 9.28 & 11.02 & 10.98 & - & - & - & - & $\mathrm{Na}_{2} \mathrm{O}$ & 0.22 & 0.13 & 9.82 & 9.65 & 0.77 & 0.54 & - & 0.15 \\
\hline K & 29.29 & 29.33 & 29.07 & 29.21 & 0.44 & - & 8.27 & 8.71 & $\mathrm{~K}_{2} \mathrm{O}$ & 36.14 & 36.47 & 41.55 & 40.05 & 16.92 & 16.35 & 26.97 & 27.78 \\
\hline $\mathrm{Ca}$ & - & - & - & - & 32.08 & 34.07 & - & - & $\mathrm{CaO}$ & 0.34 & 0.26 & 0.24 & 0.45 & 1.04 & 0.82 & 18.05 & 17.12 \\
\hline $\mathrm{Pb}$ & - & - & - & - & - & - & 61.74 & 61.65 & $\mathrm{MgO}$ & 0.26 & - & 0.16 & 0.17 & - & 0.22 & 0.23 & 0.47 \\
\hline As & - & - & - & - & - & - & 0.09 & 0.17 & $\mathrm{PbO}$ & - & - & - & - & 45.56 & 46.44 & - & - \\
\hline $\mathrm{Cl}$ & - & - & - & - & - & - & 29.38 & 29.43 & $\mathrm{As}_{2} \mathrm{O}_{5}$ & - & - & - & - & 0.55 & 0.67 & - & - \\
\hline $\mathrm{F}$ & 50.72 & 50.88 & 47.98 & 48.67 & 55.65 & 54.12 & - & - & $\mathrm{P}_{2} \mathrm{O}_{5}$ & - & - & - & - & - & - & - & - \\
\hline \multirow[t]{4}{*}{ Total } & 100.45 & 100.56 & 100.10 & 100.57 & 100.05 & 99.73 & 99.48 & 99.96 & $\mathrm{SO}_{3}$ & 28.84 & 27.65 & 48.14 & 48.09 & 35.43 & 35.09 & 47.23 & 48.18 \\
\hline & & & & & & & & & $\mathrm{F}$ & 22.71 & 23.08 & - & - & - & - & - & - \\
\hline & & & & & & & & & Total & 109.60 & 108.60 & 99.91 & 98.41 & 100.3 & 100.1 & 92.48 & 93.70 \\
\hline & & & & & & & & & $-\mathrm{O}=\mathrm{F}_{2}$ & $\begin{array}{c}9.54 \\
100.06\end{array}$ & $\begin{array}{r}9.69 \\
98.88\end{array}$ & & & & & & \\
\hline Sample ID & \multicolumn{6}{|c|}{17719 E6250 } & \multicolumn{3}{|c|}{17718 E6249 } & \multicolumn{4}{|c|}{17923 E6454 } & \multicolumn{3}{|c|}{17926 E6457 } & \\
\hline$w t \%$ & \multicolumn{2}{|c|}{ pyromorphite } & \multicolumn{4}{|c|}{ vanadinite } & & wulfen & & & & & cinaksi & & & & \\
\hline $\mathrm{SiO}_{2}$ & - & - & - & - & - & - & - & - & - & 63.13 & 63.68 & 61.92 & 61.44 & 62.70 & 62.14 & 63.28 & \\
\hline $\mathrm{Al}_{2} \mathrm{O}_{3}$ & - & - & - & - & - & - & - & - & - & - & - & - & - & - & - & - & \\
\hline $\mathrm{Na}_{2} \mathrm{O}$ & - & - & - & - & - & - & - & - & - & 6.61 & 6.65 & 7.46 & 7.07 & 5.66 & 5.87 & 8.12 & \\
\hline $\mathrm{K}_{2} \mathrm{O}$ & - & - & - & - & - & - & - & - & - & 12.24 & 10.72 & 12.38 & 13.05 & 10.65 & 11.57 & 12.57 & \\
\hline $\mathrm{CaO}$ & 0.34 & 0.12 & - & - & - & - & - & - & - & 14.02 & 15.20 & 12.83 & 12.05 & 12.43 & 10.87 & 9.69 & \\
\hline $\mathrm{FeO}$ & - & - & - & - & - & - & - & - & - & 0.05 & 1.73 & - & - & - & - & - & \\
\hline $\mathrm{MgO}$ & - & - & - & - & - & - & - & - & - & - & - & - & - & 1.35 & 1.37 & - & \\
\hline $\mathrm{MnO}$ & - & - & 1.41 & 0.97 & - & 0.55 & - & - & - & - & - & - & - & - & - & - & \\
\hline $\mathrm{PbO}$ & 81.19 & 82.02 & 79.83 & 78.23 & 80.87 & 80.04 & 57.71 & 56.62 & 56.38 & - & - & - & - & - & - & - & \\
\hline $\mathrm{CuO}$ & - & - & 1.12 & 0.66 & - & - & - & - & - & - & - & 2.89 & 3.61 & 3.34 & 4.22 & 4.64 & \\
\hline $\mathrm{MoO}_{3}$ & - & - & - & - & - & - & 27.87 & 28.94 & 28.13 & - & - & - & - & - & - & - & \\
\hline $\mathrm{V}_{2} \mathrm{O}_{5}$ & - & - & 14.05 & 15.43 & 14.99 & 15.06 & - & - & - & - & - & - & - & - & - & - & \\
\hline $\mathrm{As}_{2} \mathrm{O}_{5}$ & 0.52 & 0.44 & 0.84 & 1.23 & 1.36 & 0.99 & - & - & - & - & - & - & - & - & - & - & \\
\hline $\mathrm{P}_{2} \mathrm{O}_{5}$ & 16.11 & 15.21 & - & - & - & - & - & - & - & - & - & - & - & - & - & - & \\
\hline $\mathrm{WO}_{3}$ & - & - & - & - & - & & 14.94 & 14.68 & 15.00 & - & - & - & - & - & - & - & \\
\hline $\mathrm{Cl}$ & 2.68 & 2.75 & 3.73 & 3.44 & 3.69 & 3.58 & - & - & - & - & - & - & - & - & - & - & \\
\hline Total & 100.50 & 100.54 & 100.98 & 99.96 & 100.91 & 99.67 & 100.5 & 100.20 & 99.51 & 96.05 & 97.98 & 97.48 & 97.22 & 96.13 & 96.05 & 98.29 & \\
\hline$-\mathrm{O}=\mathrm{Cl}_{2}$ & 0.60 & 0.62 & 0.84 & 0.77 & 0.83 & 0.80 & & & & & & & & & & & \\
\hline & 99.90 & 99.92 & 100.14 & 99.19 & 100.08 & 98.87 & & & & & & & & & & & \\
\hline
\end{tabular}


Elpasolite, $\mathrm{K}_{2} \mathrm{NaAlF}_{6}$, is a cubic Na-K aluminofluoride found in five samples (Table 4) commonly as clusters of octahedra (maximum dimension ca. $15 \mu \mathrm{m}$ ), which crystallize on the surfaces or fill cavities of host rocks (Figure 14a,b). The chemical composition of elpasolite is reported in Table 12 and shows the following ranges: $11.07-11.98 \mathrm{wt} \% \mathrm{Al}_{2} \mathrm{O}_{3}, 9.28-11.02 \mathrm{wt} \% \mathrm{Na}_{2} \mathrm{O}, 29.07-29.33 \mathrm{wt} \% \mathrm{~K}_{2} \mathrm{O}$ and $47.88-50.88 \mathrm{wt} \% \mathrm{~F}$. This fluoride is quite abundant in two samples, i.e., $16256 \mathrm{E} 6787$ and 17030 E5569), hence, it was possible to obtain the cell parameters on an elpasolite-rich fraction of the first specimen by powder XRD (see Methods); the obtained data from the crystal structural refinement are the isometric system, Fm $3 m$ space group a $=8.11289(7) \AA, V=533.98(6) \AA^{3}$ and $Z=4$. These data are perfectly comparable with the literature data [53].

Sbacchiite, $\mathrm{Ca}_{2} \mathrm{AlF}_{7}$, is a Ca-aluminofluoride and was only found in sample $16256 \mathrm{E} 6787$, in needle-like crystals of ca. $30 \mu \mathrm{m}$ in length together with fluorite and anglesite (Figure 14c). Its composition (Table 12) is very similar to the species recently discovered in fossile fumarole of the AD 1944 eruption of Vesuvius [41].

Challacolloite, a K-Pb chloride with ideal formula $\mathrm{KPb}_{2} \mathrm{Cl}_{5}$ [11,35], was observed in four samples (Table 4), where tiny euhedral crystals are formed (Figure 14d) with a nearly stoichiometric composition (Table 12).

Thermessaite, $\mathrm{K}_{2} \mathrm{AlF}_{3}\left(\mathrm{SO}_{4}\right)$, is a K-bearing aluminofluoride with $\mathrm{SO}_{4}$ [54], detected in two samples (Table 4). This mineral occurs in prismatic and partially dissolved crystals (Figure 14e,f). The chemical composition is very similar to the type-locality species [55], with only trace amounts of $\mathrm{Ca}, \mathrm{Mg}$ and $\mathrm{Al}$ (Table 12).

Aphthitalite $\left[\mathrm{K}_{3} \mathrm{Na}\left(\mathrm{SO}_{4}\right)_{2}\right]$, palmierite $\left[\mathrm{K}_{2} \mathrm{~Pb}\left(\mathrm{SO}_{4}\right)_{2}\right]$, and syngenite $\left[\mathrm{K}_{2} \mathrm{Ca}\left(\mathrm{SO}_{4}\right)_{2} \cdot \mathrm{H}_{2} \mathrm{O}\right][10]$, are some of the $\mathrm{Cu}$-free sulfates randomly detected in the investigated samples (Table 4). Apthitalite and syngenite form euhedral prismatic crystals in sample 17030 E5569 and 17029 E5568, respectively (Figure 15a,b); palmierite is found in anhedral masses in three samples (Table 4 and Figure 15c). The chemical formulas of these sulfates are presented in Table 12. Moreover, thenardite $\left(\mathrm{Na}_{2} \mathrm{SO}_{4}\right)$ could be present in sample 21836 (Table 4), where EDS qualitative spectra and morphological observations seem to point to this type of sulfate.

Concerning the species belonging to phosphates, molibdates and vanadates, pyromorphite $\left[\mathrm{Pb}_{5}\left(\mathrm{PO}_{4}\right)_{3} \mathrm{Cl}\right]$ and wulfenite $\left[\mathrm{PbMoO}_{4}\right]$ occur only in two different samples (Table 4), respectively, in acicular and rounded individuals (Figure 15d,e) and both showing a nearly stoichiometric composition (Table 12). Vanadinite, $\mathrm{Pb}_{5}\left(\mathrm{VO}_{4}\right)_{3} \mathrm{Cl}$, was already described in the mottramite-bearing samples (i.e., the "vesbine" samples; see Section 4.1.5), where zoned concretions are formed with mottramite and chrysocolla (Figure 11b-e). Compared to the ideal formula, the chemical composition of the Somma-Vesuvius species shows small contents of As, in the range 0.84-1.36 wt $\% \mathrm{As}_{2} \mathrm{O}_{5}$.

Calcinaksite, $\left[\mathrm{KNaCa}\left(\mathrm{Si}_{4} \mathrm{O}_{10}\right) \cdot \mathrm{H}_{2} \mathrm{O}\right]$, the hydrous and Ca-dominant member of the litidionite group [56,57], was identified in the litidionite-bearing samples 17923 E6454 and 17926 E6457 (Table 4 and Figure 12). At the SEM scale, it is very similar to its cupric counterpart (Figure 15f), with subhedral prismatic crystals. Its composition yields $61.44-63.68 \mathrm{wt} \% \mathrm{SiO}_{2}, 5.66-8.12 \mathrm{wt} \% \mathrm{Na}_{2} \mathrm{O}, 10.72-13.05 \mathrm{wt} \%$ $\mathrm{K}_{2} \mathrm{O}, 9.69-15.20 \mathrm{CaO}$ as compositional ranges; significant contents of $\mathrm{Cu}$, i.e., $2.89-4.64 \mathrm{wt} \% \mathrm{CuO}$, were detected in some areas of calcinaksite crystals and are inversely correlated to the Ca amounts. Together with prevailing tridymite, a silica-rich glassy phase (Figure 13d) shows a composition corresponding to $\mathrm{SiO}_{2}$ 66.12, $\mathrm{Al}_{2} \mathrm{O}_{3}$ 1.41, $\mathrm{TiO}_{2}$ 1.16, $\mathrm{FeO} 0.10, \mathrm{MgO} 0.37, \mathrm{Na}_{2} \mathrm{O}$ 1.52, $\mathrm{K}_{2} \mathrm{O}$ 6.47, $\mathrm{CaO} 0.91, \mathrm{CuO} 3.33, \mathrm{Cl}$ $0.78(\mathrm{wt} \%)$; a phase indicated as opal was also identified in the literature in these type of rocks $([10,11]$ and references therein); however, further chemical, XRD and spectroscopic investigations are ongoing on the whole litidionite-related paragenesis. 


\section{Discussion}

\subsection{General Mineralogical Remarks on Copper Minerals and Associated Phases}

Various types of halides, both Cu-bearing and $\mathrm{Cu}$-free, occur in the investigated samples (Table 4). Atacamite is the most common (hydroxyl)halide in museum specimens, which span from the AD 1631 lavas (Scala, Camaldoli, Uncino; Figure S1) to the products of the AD 1870-1872 and 1880-1906 periods (Tables 2 and 4). A rare occurrence of distinct and well-crystallized individuals of atacamite has been found in a lava fragment by Russo et al. [58] (Villa Inglese, Torre del Greco; Figure S1), who also reported, for the atacamite-bearing 1631 lavas of Camaldoli and Villa Inglese, a more likely medieval age (AD 938 and 1037). In the studied samples, this mineral is coeval with the Cu-vanadates and silicates, azurite and some oxides (hematite, cuprite). The origin of atacamite is commonly related to the supergene oxidation zone of $\mathrm{Cu}$ deposits (i.e., porphyry copper, [7]), especially under arid and saline conditions $[59,60]$. However, it is also related to fumarolic deposition and to weathering of sulfides in subsea black smoker deposits in deep seawater seafloor hydrothermal sites; in these areas, atacamite and paratacamite are the most stable copper salts at the $\mathrm{pH}$ and Eh of cold deep seawater, undersaturated in $\mathrm{CaCO}_{3}$, and appear to be the ultimate sink for the $\mathrm{Cu}$ leached by the hydrothermal systems from the oceanic crust [61]. At Somma-Vesuvius, this mineral has a fumarolic genesis, being deposited during the latest phases of the magma cooling mainly along the lava fractures, as described in the literature $([35,58]$ and references therein). It was also observed $[35,53]$ that atacamite is associated with azurite, "vesbine" and various oxides (hematite, hausmannite and rarely cuprite), as quite similarly observed in the present research.

Paratacamite, the trigonal polymorph of atacamite, was identified in very few occurrences and in the same atacamite-bearing samples, although in restricted parts. It occurs as tiny clusters of crystals or as alteration of tenorite in products of the 1872-1882 period of the historical activity. In agreement with Russo and Punzo [10], the transformation of tenorite to paratacamite is due to the reaction of fumarolic $\mathrm{HCl}$ with the copper oxide, i.e., $2 \mathrm{CuO}+\mathrm{HCl}+\mathrm{H}_{2} \mathrm{O}=\mathrm{Cu}_{2}(\mathrm{OH})_{3} \mathrm{Cl}$. The compositional features of this basic cupric chloride show the presence of $\mathrm{Zn}$ in its crystal lattice; it was demonstrated by Braithwaite et al. [62] that paratacamite is defined as a mineral with the rhombohedral structure, and composition $\mathrm{Cu}_{3}\left(\mathrm{Cu}, \mathrm{M}^{2+}\right)(\mathrm{OH})_{6} \mathrm{Cl}_{2}$, in which $\mathrm{Cu} / \mathrm{M}^{2+}{ }_{\text {atomic }}$ is $~ 11-7$, corresponding to $\sim 1 / 3$ to $1 / 2$ the occupancy of the non-Jahn-Teller site by $\mathrm{M}^{2+}$, which is an essential stabilizing non-Jahn-Teller-distorting cation of suitable radius, such as $\mathrm{Zn}^{2+}, \mathrm{Ni}^{2+}, \mathrm{Co}^{2+}, \mathrm{Fe}^{2+}, \mathrm{Cd}^{2+}$ and $\mathrm{Mg}^{2+}$.

Interestingly, together with the $\mathrm{Cu}$-halides, several $\mathrm{Cu}$-free varieties have been found in various mineral assemblages of the studied Somma-Vesuvius specimens, mainly belonging to chlorides and fluorides; halite $(\mathrm{NaCl})$, sylvite $(\mathrm{KCl})$ and fluorite $\left(\mathrm{CaF}_{2}\right)$ often occur together, and also in various associations with elpasolite, sbacchiite, challacolloite, thermessaite. In particular, elpasolite belongs to cubic perovskites [63], as the mineral parascadolaite discovered for the first time at Vesuvius [64]; other rare fluorides were also very recently found, such as the already cited sbacchite [41] and verneite [65]. These fluorides are formed by the reaction of HF with the surrounding rocks, indicating environments with $\mathrm{T}>500{ }^{\circ} \mathrm{C}$. Challacolloite was found in the 1906 fumaroles of HT [11,12,35], but no temperature data were recorded; this mineral can form at a temperature range of $360^{\circ} \mathrm{C}$ (Vulcano island, Italy) to $550-390^{\circ} \mathrm{C}$ (Satsuma-Iwojima volcano, Japan) [12]. Thermessaite is a rare mineral discovered at Vulcano island, southern Italy [55] in medium temperature fumarole (around $300{ }^{\circ} \mathrm{C}$ ) in sub-mm colorless prismatic crystals associated with alunite, sassolite, anhydrite, and metavoltine; it was also identified at Vesuvius in fumaroles from recent activity by Campostrini et al. [54].

Among the cupric oxides, cuprite is restricted to one sample, labelled as "1631 lava. As many other oxidized copper minerals, cuprite is quite common in the weathered portions of many copper sulfide deposits, whereas is rare in volcanic environments. At Vesuvius, cuprite was detected in the lavas of Camaldoli and Scala [10] (Figure S1), in associations with atacamite. Tenorite is more widespread compared to cuprite, both in the investigated samples and in the occurrences from the literature ([13] and references therein); in fact, in the studied samples, tenorite was detected in various rocks related to 
1631 to 1906 eruptions, whereas according to the literature [10], this oxide was identified in scoriae of the 1760 eruption and in all the eruptions from 1825 onward, with particularly abundant and large crystals in the products of the 1944 eruptive episode. Tenorite is typical of the HT fumaroles (K-Na salts bearing, $\mathrm{T}>400{ }^{\circ} \mathrm{C}$ ) and originates by interaction of gaseous $\mathrm{CuCl}_{2}$ and water vapor, according to the reaction $\mathrm{CuCl}_{2}+\mathrm{H}_{2} \mathrm{O}=\mathrm{CuO}+2 \mathrm{HCl}[10,15]$. As stated before, tenorite can be subsequently altered by $\mathrm{HCl}$ brines to form paratacamite.

The $\mathrm{Cu}$-bearing carbonates are represented by azurite and malachite, only found in two samples and mainly in association with atacamite. As also reported in the literature, these minerals are rare at Vesuvius and have been found in the so-called 1631 lavas (azurite with atacamite and "vesbine"), in an ejectum of Lagno Macedonia with magnetite and malachite, and in fumarolic products of the 1872 eruption together with connellite, or in various ejecta (malachite) [10]. The general scarcity of carbonates ( $\mathrm{Cu}$-bearing or not) in the fumarolic mineralizations is not surprising (notwithstanding the abundant $\mathrm{CO}_{2}$ in volcanic gases), considering that the typical high acidity of the fumarolic environments makes most carbonates unstable [35]. While azurite composition in the studied samples is close to the ideal formula, malachite is distinctly $\mathrm{Zn}$-bearing, with a partial substitution of $\mathrm{Cu}^{2+}$ by $\mathrm{Zn}^{2+}$, giving the formula: $\left(\mathrm{Cu}_{1-\mathrm{x}} \mathrm{M}_{\mathrm{x}}\right)_{2}(\mathrm{OH})_{2} \mathrm{CO}_{3}(\mathrm{M}=\mathrm{Zn}, \mathrm{Mg}, \mathrm{Co}, \mathrm{Ni}$, etc. $)$ for members of the malachite-rosasite group [66,67].

Cu-bearing sulfates are represented by the largest variety of species in the investigated Somma-Vesuvius samples (followed by the whole of halides) and have been recognized in all the products of the recent activity. Even though these minerals belong to different systematic subgroups of sulfates, they can be gathered in main three types, i.e., (i) anhydrous sulfates (chalcocyanite, cryptochalcite, \pm dravertite), (ii) anhydrous sulfates with hydroxyl or halogens (brochantite, euchlorine, linarite, \pm chlorothionite), and (iii) hydrous sulfates (chalcanthite, cyanochroite, kröhnkite, leightonite, natrochalcite, \pm boothite). These sulfates can be composed of $\mathrm{Cu}$ only, or of $\mathrm{Cu}-\mathrm{K}, \mathrm{Cu}-\mathrm{Na}, \mathrm{Cu}-\mathrm{K}-\mathrm{Na}$, $\mathrm{Cu}-\mathrm{Pb}$ and $\mathrm{Cu}-\mathrm{Mg}$ ( \pm anions, $\pm \mathrm{H}_{2} \mathrm{O}$ ). As also observed by Pekov et al. [6], the alkali cations have an important role in the chemical feature of the fumarolic minerals, just as the sulfates; indeed, according to these authors, 46 of 86 sulfates and other oxysalts plus chlorides contain $\mathrm{K}, \mathrm{Na}$ and Cs, whereas only 16 of 174 copper minerals from the oxidation zones of sulfide ores show alkali elements (K and/or $\mathrm{Na}$ ). Hence, the alkali cations represent a key factor in determining the unique crystal-chemical nature of fumarolic copper minerals. A remarkable feature was indicated by Balić-Žunić et al. [35] for the sulfates found in fumaroles, i.e., the characteristic existence of several hydrous forms associated with the anhydrous ones. These varieties have different stability fields, that depend on the humidity and temperature conditions and hence, can appear in various zones of the same fumarole. The anhydrous sulfates are generally unstable and readily hydrate under atmospheric conditions [35]. This is true also for the Cu-bearing sulfates, for which it is possible to observe the anhydrous phases and the hydrous counterparts; an example is chalcocyanite $\left[\left(\mathrm{Cu}(\mathrm{SO})_{4}\right]\right.$, which rapidly changes to chalcanthite $\left[\mathrm{CuSO}_{4} \cdot 5\left(\mathrm{H}_{2} \mathrm{O}\right)\right]$ [35]. In the studied specimens, these two sulfates were also found in the same sample (127656 E1295), probably in relation to an incomplete alteration (hydration) process of chalcocyanite. However, it is quite common to find complex and various mixtures of the above-mentioned two or three types of sulfates in the same sample, for instance (Table 4):

- $\quad$ chalcocyanite-euchlorine (10907 D1358)

- $\quad$ cryptochalcite-euchlorine-natrochalcite (12912 E1457).

It is interesting to note that SEM studies also support the observation that hydrous Cu sulfate generally appears to be as later phases compared to the other sulfates in the paragenetic sequence. Among the identified varieties, kröhnkite and leightonite were recently reported as new occurrences among Vesuvius fumarolic mineral by Campostrini et al. [54], whereas brochantite, cryptochalcite and natrochalcite detected in the present study are, to the authors' knowledge, the first recorded occurrences at Vesuvius. The same is valid for boothite and dravertite, if their presence was confirmed by our ongoing investigations. 
$\mathrm{Cu}$-bearing vanadates characterize few studied samples, commonly indicated as vesbine-bearing and restricted to the occurrences related to 1631 lavas. They are represented by $\mathrm{OH}$ - or $\mathrm{H}_{2} \mathrm{O}$-bearing minerals, as mottramite and volborthite, and by the anhydrous phase, starovaite. Mottramite is the prevailing cupric vanadate, at least in the investigated samples, and can be found in mineral associations, i.e., together with vanadinite + chrysocolla + wulfenite, vanadinite + chrysocolla + tenorite, or chrysocolla + starovaite + atacamite. Volborthite occurs with atacamite just in one sample. Both starovaite (the second worldwide occurrence) and vanadinite are the first occurrences at Vesuvius, to the authors' knowledge. According to Russo and Punzo [10] and Russo et al. [58], it is more reliable the attribution of vesbine to volborthite, even though mottramite and vesigniéite have been also indicated as other possible mineral components; indeed, the present study pointed out that the so-called vesbine of Vesuvius is a complex mixture of various minerals, alternatively composed of $\mathrm{Cu}, \mathrm{Cu}-\mathrm{Pb}, \mathrm{Pb}$ and $\mathrm{Cu}-\mathrm{K}$ vanadates and of $\mathrm{Cu}$-bearing silicates. According to Pekov et al. [6], $\mathrm{Cu}$ vanadates are important minerals in volcanic exhalations and their number is related to the fumarolic environment of two significant occurrences, i.e., Izalco (San Salvador) and Tolbachik (Kamchatka) volcanoes, is almost twice the number of supergene $\mathrm{Cu}$ vanadates. As for sulfates, the $\mathrm{H}$-free vanadates can be considered more specific to the volcanic domain.

Tsumebite, a rare $\mathrm{Cu}-\mathrm{Pb}$ phosphate, was detected in our study for the first time at Vesuvius in a complex and multimineralic assemblage; this mineral typically occurs as the secondary phase in the oxidized zone of As-bearing $\mathrm{Cu}-\mathrm{Pb}$ deposits, with other secondary oxidized minerals. In fact, according to Pekov et al. [6], copper phosphates (as well as carbonates) are even unknown in volcanic exhalations, unlike in supergene formation, where they are numerous and widespread. Moreover, Balić-Žunić et al. [35] affirmed that phosphate group gives limited or null contribution to the mineralogy of the European fumarolic occurrences. In light of this, Vesuvius occurrence has an exceptional character.

The copper silicates identified in the studied samples are chrysocolla and litidionite, related to different type of rocks. Chrysocolla was only found in the thin encrustations on 1631 lava with atacamite or with the $\mathrm{Cu}$-vanadates. Following the literature [10], at Vesuvius, this silicate was extremely rare, and observed as light green encrustations in a lava fragment of the 1872 eruption (Le Novelle quarry, Ercolano; Figure S1), with atacamite, apatite, hematite, magnetite and pyroxene, of presumably pneumatolytic origin. Chrysocolla is commonly found in weathered portions of many copper sulfide deposits, whereas it is very poorly represented, as $\mathrm{Cu}$ phosphates and carbonates, in volcanic exhalation products. Litidionite is even rarer and restricted to a unique occurrence, i.e., to thermally modified pyroclastic fragments by the fumarolic activity related to the 1872 eruption. The litidionite-bearing paragenesis is mainly composed of tridymite, calcinaksite (the second recorded worldwide occurrence), wollastonite and diopside and is typical of high-temperature alteration processes at the rock-fumaroles interface. Interestingly, the first discovery of this mineral was in a calcic xenolith hosted by an alkaline basalt of Bellerberg volcano (Eifel, Germany) as the product of contact metamorphism (metasomatism); the Bellerberg paragenesis consists of calcium silicates and CHS phases (wollastonite, gehlenite, browmillerite, tobermoreite, ettringite, etc.), which are also typical components of cement clinker and cement materials [56,57].

Finally, in the studied samples, we did not find $\mathrm{Cu}$ sulfides, such as chalcopyrite, covellite, chalcocite, or $\mathrm{Cu}$ sulfosalts; only sporadic grains of galena were observed. Base metal-bearing sulfides are quite rare in fumarolic products at Vesuvius $[10,68]$, and can be present in products of different ages (see Table 2 for copper sulfides). Indeed, Balić-Žunić et al. [35] argued that metallic sulfides are confined to deeper parts of a volcanic system with its high-temperature hydrothermal conditions and rarely appear as sublimates, hence, they commonly occur in small amounts on the surface of the fumarole deposits.

\subsection{Genetic Considerations}

The Cu-bearing mineral assemblages observed in the investigated samples (or sub-samples) from Vesuvius are often very heterogeneous and can involve minerals that crystallized in different 
temperature conditions. In fact, Vesuvius can be distinguished by an oscillation in term of oxidizing vs. reducing conditions, mainly in the periods immediately following the eruptions [35], as well as of temperature values. However, following the literature [10,11,14,35-41], most of the minerals found in the present research may be formed from high- to moderate-temperature fumaroles, at a temperature ranging from $300^{\circ} \mathrm{C}$ to more than $650{ }^{\circ} \mathrm{C}$. At higher temperatures, chlorides and fluorides (e.g., halite, sylvite, fluorite, elpasolite, sbacchiite) and alkali sulfates (e.g., thénardite) prevail. On the contrary, $\mathrm{Cu}-\mathrm{Cl}$ oxyhalides and hydrohyhalides (as atacamite and paratacamite), $\mathrm{Cu}$-bearing sulfates (e.g., chalcocyanite, euchlorine) and tenorite, together with a set of $\mathrm{Pb}$-bearing minerals (e.g., cotunnite, pseudocotunnite, palmierite), hematite and sulfides probably formed at lower temperatures. This latter group can likely include other phases, even though with different precipitation temperatures, such as linarite, the $\mathrm{Cu}$-bearing and $\mathrm{Cu}$-free vanadates, chrysocolla, and tsumebite.

According to Pekov et al. [6], similar temperature ranges can be assumed for the origin of $\mathrm{Cu}$ minerals of the Tolbachik volcano (Kamchatka, Russia); these authors distinguished two main groups of minerals, formed either in the hot zones of fumarolic system, corresponding to a $\mathrm{T}>200{ }^{\circ} \mathrm{C}$, mainly in the range $\sim 400-700{ }^{\circ} \mathrm{C}$, or in the moderately hot zones of fumarolic system, with a $\mathrm{T}<200{ }^{\circ} \mathrm{C}$ and mainly in the interval of $70-150^{\circ} \mathrm{C}$. This study shows that anhydrous sulfates, as chalcocyanite, cryptchalcite, euchlorine and dravertite can be formed by hot fumarolic system. Instead, hydrous sulfates, i.e., cyanochroite, leightonite, natrochalcite and kröhnkite, can be related to lower temperature conditions and belong to the second group. In agreement with these observations, starovaite should belong to the high $\mathrm{T}$ group, being formed before chrysocolla, that likely had lower precipitation temperatures.

Litidionite and its peculiar paragenesis can be formed as a product of very localized high-temperature (exhalation-related) alteration processes of hosting silicates and with the introduction of other chemical components by fluids (e.g., $\mathrm{Cu}^{2+}$ ), also in agreement with that observed for the Eifel calcinaksite-bearing rocks; these phenomena can occur likely at a temperature of $>600{ }^{\circ} \mathrm{C}$.

Other minerals randomly detected in the investigated samples, such as gypsum, anhydrite, alum-K, alunite, calcite and opal, are related to the last phases of mineral deposition, characterized by lower temperatures of exhalation phenomena, with a temperature rarely higher than $100{ }^{\circ} \mathrm{C}($ see Section 2).

In their thorough review, Pekov et al. [6], have carried out a comparison between the crystal-chemical characteristics of $\mathrm{Cu}$ minerals found in volcanic fumarole environment and those formed under supergene conditions (i.e., the oxidation zone of sulfides ores, at T-P surface condition and under the influence of aqueous solutions). Even though the bulk of oxygen- and halogen-bearing $\mathrm{Cu}$ minerals occur primarily in the oxidation zones of sulfide ores (supergene environment), these authors report that more than one hundred new minerals were recently discovered in volcanic exhalation environment, showing great diversity and originality of motifs formed by the $\mathrm{Cu}^{2+}$-centred coordination polyhedral for both the mineral sets. Our research confirms this statement, demonstrating that a large variety of the $\mathrm{Cu}$ minerals formed from fumarolic activity at Vesuvius. Pekov et al. [6] also showed that in particular, H-free copper sulfates and vanadates of fumarolic origin are numerous and structurally diverse, but are unknown in the supergene environment, which is instead characterized by $\mathrm{Cu}^{2+}$-based sulfates, vanadates and chlorides containing $\mathrm{OH}$-bearing groups.

\subsection{Crystal Structure and Complexity Considerations}

A new approach for quantifying the structural complexity of a crystalline matter is based on the TOPOS software package [45]. The information-based complexity measures made possible to widely use the compelxity parameter as a tool for studying the evolution of mineral formation in various systems [46,69-71]. Mineral structures can be classified into very simple (0-20 bits, i.e., binary digits), simple (20-100 bits), intermediate (100-500 bits), complex (500-1000 bits), and very complex (>1000 bits). According to the proposed quantitative approach, the crystal structure can be viewed as a reservoir of information encoded in its complexity [46]. Regarding this topic, we give a brief 
description of crystal structures of Cu-minerals from Vesuvius volcano and discuss their complexity in the context of different periods of volcanic activity.

Oxide minerals represent the simplest group from their structural complexity of Somma-Vesuvius $\mathrm{Cu}$-minerals minerals. The crystal structure of tenorite Figure 16 exhibits a framework based on $\mathrm{CuO}_{4}$ planar groups polymerized through shared vertexes. On the polyhedral approach, the crystal structure of curpite can be described as based on the O-centered tetrahedral framework, whereas each [OCu$\left.u_{4}\right]$ tetrahedra is connected by shared vertexes.

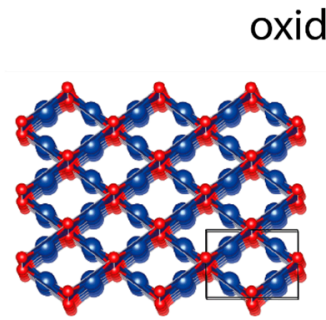

tenorite oxides:

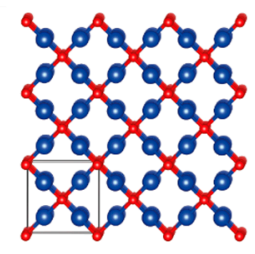

cuprite

silicates:

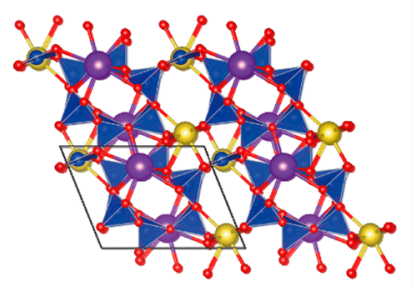

litidionite

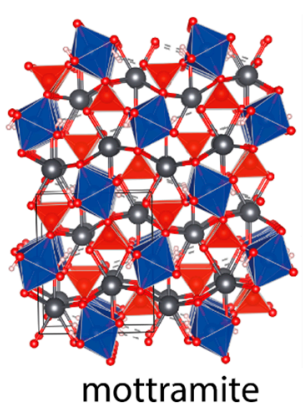

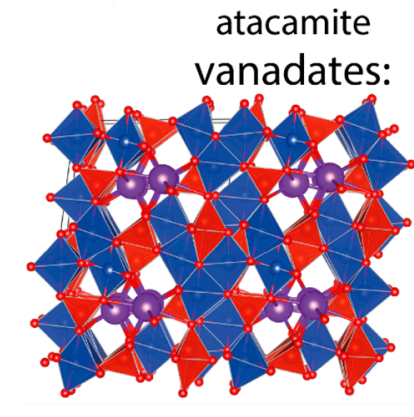

starovaite

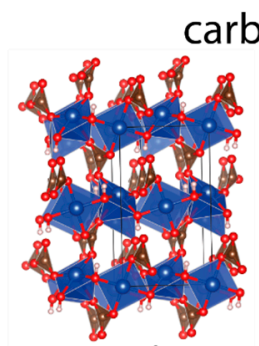

azurite carbonates:

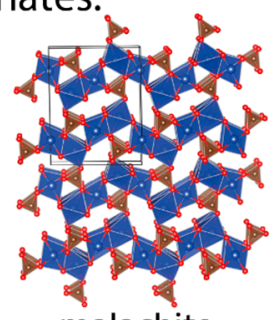

malachite hydroxyhalides:

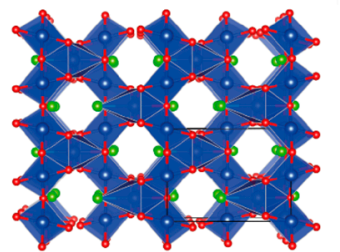

atacamite vanadates:

Figure 16. Projection of crystal structures of oxides, carbonates, silicates, hydroxyhalides, vanadates from the Somma-Vesuvius volcanic complex. The Cu-centered polyhedra are shown by blue color, carbonate-brown, vanadium tetrahedra—red, silicon tetrahedra-blue. The chlorine atoms are shown as green spheres, oxygen—red, potassium—purple, led—gray, sodium—yellow.

Vesuvius carbonates are represented by azurite and malachite. The structure of azurite based upon $\mathrm{Cu}_{2} \mathrm{O}_{8}$-chains connected to the complex layers via $\mathrm{CuO}_{4}$ planar groups copper layers with strong magnetic properties [72] linked by carbonate groups. In the structure of malachite, there are two independent copper sites in square-planar and octahedral coordination. The edge-shared octahedral columns connected with adjacent $\left[\mathrm{CuO}_{4}\right]$ groups form a zig-zag like pattern combined with each other by $\mathrm{CO}_{3}$-groups. The importance of hydrogen bonding in malachite and azurite structures should be noted.

There are two copper silicate minerals in the investigated samples, but the crystal structure of chrysocolla still unsolved. The crystal structure of litidionite consists of tubular $\left[\mathrm{Si}_{8} \mathrm{O}_{20}\right]$ chains with a hexagonal cross-section, which are interconnected by $\left[\mathrm{CuO}_{4}\right]$ planar groups [56]. The structural cavities are filled by the $\mathrm{Na}$ and $\mathrm{K}$ atoms. 
Hydroxyhalides include atacamite and its polymorph paratacamite. Generally, both minerals have the same net-like motif formed chains of $\mathrm{CuO}_{4}$ planar groups connected with perpendicular chains based by $\left[\mathrm{CuO}_{5} \mathrm{Cl}\right]$ distorted octahedra. The paratacamite structure is more ordered, one half distorted octahedra changed by $\left[\mathrm{CuO}_{6}\right]$ and the other half changed by $\mathrm{CuO}_{4}$ planar groups, whereas $\mathrm{Cl}^{-}$anions filled voids $[73,74]$.

There are three vanadates found at the Vesuvius volcano. In the crystal structure of mottramite distorted $\mathrm{Cu}$-octahedra connected by shared edges forms infinite chains along the $b$ axis. The $\mathrm{V}^{5+}$ cations occupy slightly distorted tetrahedra connected by three oxygen vertexes with $\left[\mathrm{CuO}_{6}\right]$-based chains and one oxygen involved in hydrogen bonding. The $\mathrm{Pb}^{2+}$ cations are seven-coordinated with bonds in the range 2.45-2.80 [75]. There are five independent $\mathrm{Cu}$ sites in the crystal structure of starovaite, which has tetragonal pyramidal or trigonal bipyramidal coordination. They form complex $\infty\left[\mathrm{Cu}_{5} \mathrm{O}_{13}\right]$ sheets connected via $\left[\mathrm{VO}_{4}\right]$ tetrahedra in the framework. The cages in the framework are occupied by 10-coordinated $\mathrm{K}$ atoms [76]. Volborthite is a well known type of layered structure with octahedral layers based on $\left[\mathrm{CuO}_{6}\right]$ distorted octahedra with $1 / 3$ empty sites. Such layers are connected with $\left[\mathrm{V}_{2} \mathrm{O}_{5}\right]$ nesovanadate groups that form channels populated by water molecules [77].

The most complex Vesuvius Cu-minerals are related to the sulfates, which are represented by group of 14 minerals (Figure 17). Structurally, they can be divided into five subgroups based on the arrangement of $\mathrm{Cu}$ atoms: single $\mathrm{Cu}$-octahedra (kröhnkite, chalcanthite, cyanochroite, boothite, leightonite); single $\mathrm{Cu}$-centered squares (chlorothionite); octahedral chains of edge-shared $\mathrm{Cu}$-octahedra (dravertite, linarite, chalcocyanite, natrochalcite, tsumebite); complex chains (brochantite); complex clusters (euchlorine, cryptochalcite).

The dominant motif of the kröhnkite structure is the chains of $\left[\mathrm{SO}_{4}\right]$ tetrahedra connected with single $\mathrm{Cu}$ octahedra, extending along the $\mathrm{c}$ axis; these chains are linked together by $\mathrm{Na}$ atoms coordinated by seven anions at distances between 2.39 and $2.57 \AA$ [78]. The chalcanthite structure is based on infinite chains of distorted $\mathrm{Cu}$-octahedra with an edge shared Mg-octahedra. These chains are held together by corner-shared sulfate tetrahedra and a hydrogen bonding system [79]. In the cyanochroite structure, each $\mathrm{Cu}$ atom is coordinated by six water molecules and connected via hydrogen bonds with $\left[\mathrm{SO}_{4}\right]$ tetrahedra and $\mathrm{K}$ atoms [80]. In this work, boothite is the second complex mineral and its structure is similar to that of cyanochroite based on Cu-octahedra with six water molecules and hydrogen-bonded with $\left[\mathrm{SO}_{4}\right]$ tetrahedra [81]. Generally, the leightonite structure has a framework character. To date, only a disordered model has been proposed [82]. In this model, $\mathrm{Cu}$ atoms have square-planar coordination, but octahedral if considering mixed K/O sites. All equatorial $\mathrm{O}$ atoms in the copper octahedra are connected with corner-shared sulfate groups. The Ca atoms are eight-coordinated, whereas six oxygens are shared for sulfate groups.

In the chlorothionite crystal structure, the $\mathrm{Cu}$ atoms are square-coordinated. In chlorothionite, $\mathrm{Cu}$ is coordinated by two $\mathrm{Cl}$ and two $\mathrm{O}$ atoms, whereas oxygen atoms are edge for adjacent $\left[\mathrm{SO}_{4}\right]$ tetrahedra and chlorine atoms bonded with $\mathrm{K}$ [83].

The crystal structures of dravertite, linarite, chalcocyanite, natrochalcite, tsumebite consist of $\mathrm{Cu}$ or mixed $\mathrm{Cu}-\mathrm{Mg}$ (dravertite) layers of edge-shared octahedral chains. In terms of structure, dravertite can be considered as a cation-ordered derivative of chalcocyanite, with alternating $\mathrm{Cu}$ - and $\mathrm{Mg}$-centred octahedra in cationic chains [50]. In chalcocyanite, the structure of octahedral chains parallel to [010] is connected to a framework by $\left[\mathrm{SO}_{4}\right]$ tetrahedra [84]. In the linarite structure, octahedral $\mathrm{Cu}$-chains are connected with vertex-shared $\left[\mathrm{SO}_{4}\right]$ tetrahedra and eight-coordinated $\mathrm{Pb}$ atoms [85]. The sulfate groups are connected through $\mathrm{Pb}$ atoms; thus, they form a double $(\mathrm{Pb}-\mathrm{S})$ layer between $\mathrm{Cu}$-layers. Similarly to other members of the brackebuschite supergroup, the tsumebite crystal structure contains a cubic closest-packed array of $\mathrm{O}$ and $\mathrm{Pb}$ atoms with infinite chains of edge-sharing distorted $\mathrm{Cu}$ octahedra decorated by two unique $\left[\mathrm{SO}_{4}\right]$ and $\left[\mathrm{PO}_{4}\right]$ tetrahedra [86]. The $\mathrm{Cu}-\mathrm{S}$ layers in the natrochalcite structure are close to those in chalcocyanite and are built from $\left[\mathrm{Cu}_{2} \mathrm{OH}\left(\mathrm{SO}_{4}\right)_{2} \cdot 2 \mathrm{H}_{2} \mathrm{O}\right]$ sheets and are interconnected by $\mathrm{Na}^{+}$ions and hydrogen bonds [87]. 


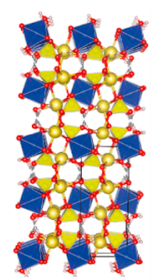

kröhnkite

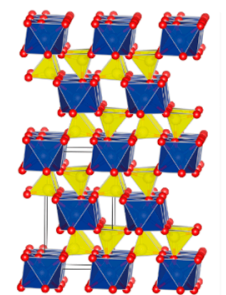

chalcocyanite

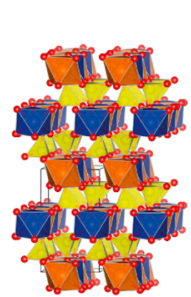

dravertite

sulphates:

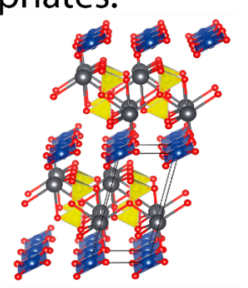

linarite

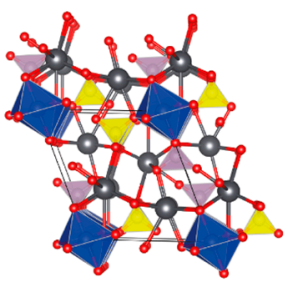

tsumebite

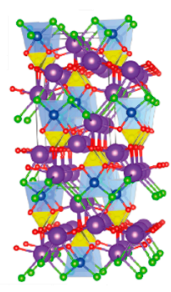

chlorothionite

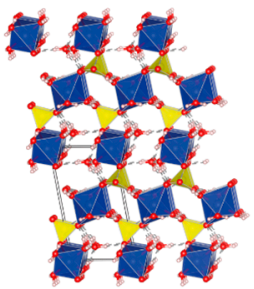

chalcantite

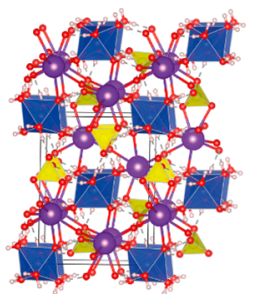

cyanochroite

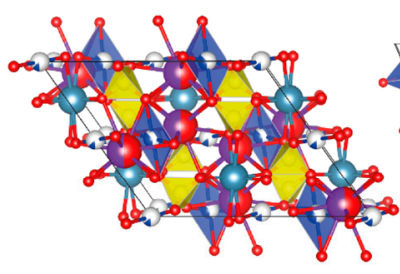

leightonite

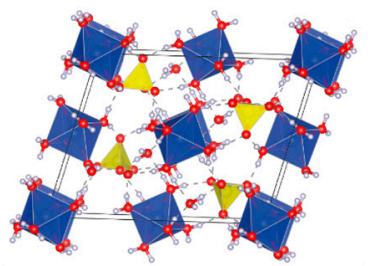

boothite
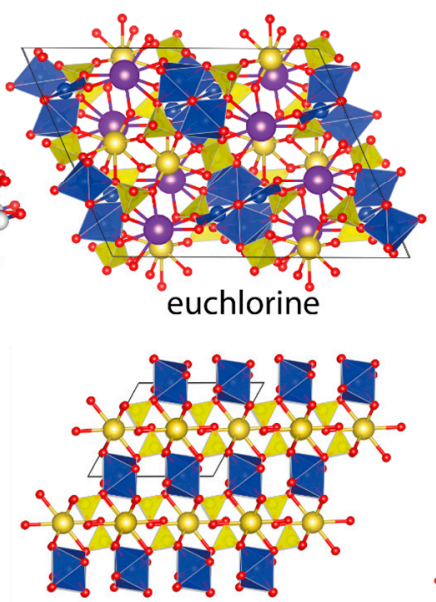

natrochalcite

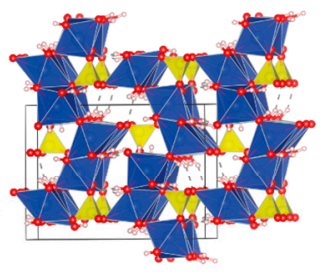

brochantite

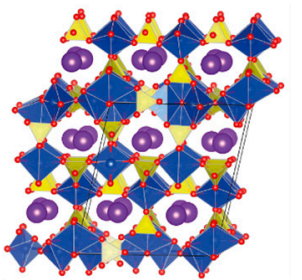

cryptochalcite

Figure 17. Projection of crystal structures of sulfates from the Somma-Vesuvius volcanic complex. Cu-polyhedra is indicated in blue, Mg-octahedra-orange, S-tetrahedra-yellow, P-tetrahedra—pink. Oxygen atoms are shown as red spheres, chlorine-green, potassium—purple, led-gray, sodium-yellow. Hydrogen-bonding systems are shown as dashed lines.

In the brochantite structure, two distorted $\mathrm{Cu}$ octahedra are interconnected through common edges to build infinite planar double chains running along the $c$ axis. These chains are interconnected by sharing vertices to build 'zig-zag' chains running along $c$. Each $\left[\mathrm{SO}_{4}\right]$ tetrahedra is connected to three adjacent double chains [88].

For the structures containing an "additional" oxygen atom, it is convenient to use an approach to understand the structure in terms of anion-centered coordination polyhedra [89]. In the euchlorine structure, "additional" non-sulfate oxygen atoms are considered to form two independent oxocentered $\left[\mathrm{OCu}_{4}\right]$ tetrahedra which share a common Cu1-Cu1 edge, thus forming an $\left[\mathrm{O}_{2} \mathrm{Cu}_{6}\right]$ dimer. Two $\mathrm{S}$-centered sulfate tetrahedra are attached 'face-to-face' to the dimers. And one $\left[\mathrm{SO}_{4}\right]$ tetrahedra provides the linkage of these clusters in two dimensions to form $\left[\mathrm{Cu}_{3} \mathrm{O}\left(\mathrm{SO}_{4}\right)_{3}\right]$ layers parallel to the $b c$ plane. Potassium and sodium atoms are located in the interlayer [90].

The crystal structure of cryptochalcite is based on the heteropolyhedral framework $\left[\mathrm{Cu}_{5} \mathrm{O}\left(\mathrm{SO}_{4}\right)_{5}\right]$ composed of two types of alternating $\mathrm{Cu}-\mathrm{S}-\mathrm{O}$ polyhedral layers $\left[\mathrm{Cu}_{2}\left(\mathrm{SO}_{4}\right)_{2}\right]$ and $\left[\mathrm{Cu}_{3} \mathrm{O}_{\left.\left(\mathrm{SO}_{4}\right)\right]_{2}}\right.$ coplanar to the $a b$ plane and connected via $\mathrm{SO}_{4}$ tetrahedra. The first layer consists of clusters formed 
by four edge-sharing octahedra with signifificant Janh-Teller distortion. The second layer is formed by two isolated $\mathrm{Cu}$-centered tetragonal pyramids alternating with two $\mathrm{Cu}$-centered trigonal bipyramids. Inside the layers, $\mathrm{Cu}$-polyhedra are connected via corner-shared $\left[\mathrm{SO}_{4}\right]$ tetrahedra, interstices filled by K atoms [49].

The complexity totals for $\mathrm{Cu}$-minerals are 1449, 2101 and 550 bits for temperature ranges of 50-200 ${ }^{\circ} \mathrm{C}, 200-400{ }^{\circ} \mathrm{C}$ and $400-700{ }^{\circ} \mathrm{C}$, respectively (Figure 18a). At first sight, this is not in agreement with Goldsmith's simplexity principle [91]. The observed splash of complexity for middle temperature $\mathrm{Cu}$-minerals is connected with the presence of "additional oxygen" in formula. The additional oxygen in the structure makes possible the organization of $\mathrm{Cu}$-clusters, which can also be described in terms of oxy-centered crystallography [6]. If we consider the complexity of all minerals in assemblages including Cu-free minerals, the totals would be 1863, 2245 and 1126 bits (Figure 18b). The means of complexity for middle-temperature minerals is still higher than for low-temperature ones. This contradiction with the simplexity principle is probably due to a lack of information about Cu-free minerals, or due to destruction of some water-soluble minerals under atmosphere conditions.
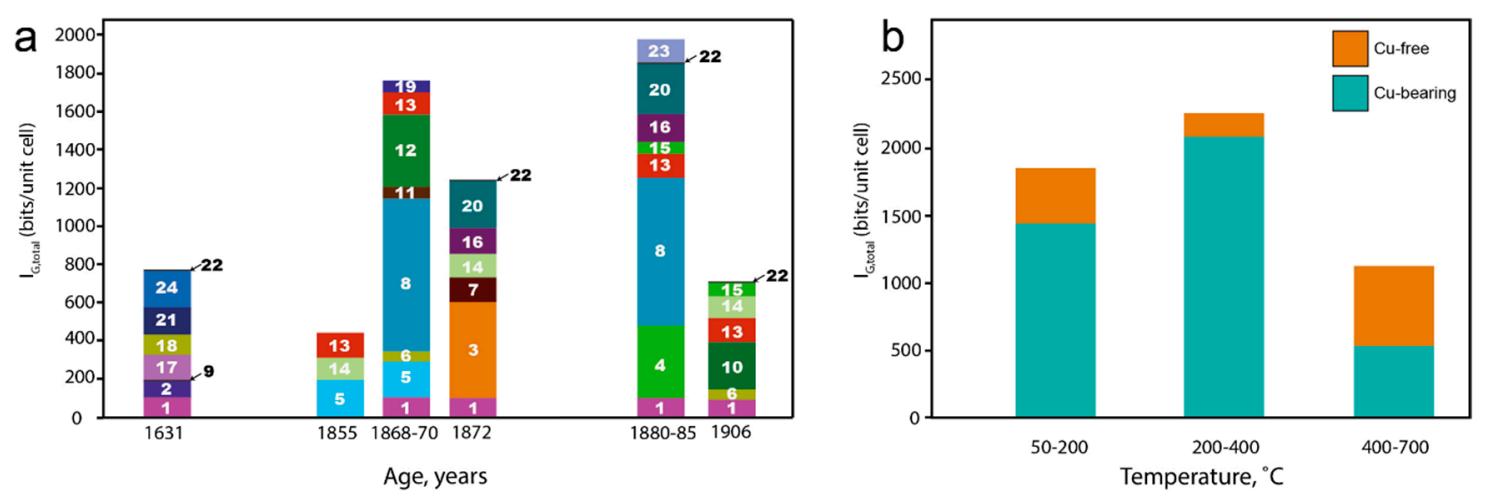

Figure 18. (a) Total structural information content $\left(I_{G \text {,total }}\right)$ vs. sample age at different periods of Vesuvius volcano activity (the eruption ages are mainly based on the timings indicated in the samples classification labels, see text; for more detailed information on the eruptions ages of the recent activity, see, for instance, [30] and references therein): 1-atacamite, 2-azurite, 3-boothite, 4-brochanitite, 5-chalcantite, 6-chalcocyanite, 7-chlorothionite, 8-cryptochalcite, 9-cuprite, 10-cyanochroite, 11-dravertite, 12-euchlorine, 13-kröhnkite, 14-leightonite, 15-linarite, 16-litidionite, 17-malachite, 18-mottramite, 19-natrochalcite, 20-paratacamite, 21-starovaite, 22-tenorite, 23-tsumebite, 24-volborthite). (b) Total complexity of Cu-mineral assemblages with different temperature formation.

The maximal values of total complexity correspond to the samples attributed, at least according to the museum labels, to the $1868-1870,1872-1875$ and 1880-1885 eruptions. The main contribution here is given by cryptochalcite and boothite minerals. According to Ivanyuk et al. [92], a relationship between massif sizes and the number of minerals known in them can exist; similarly, the relationship between different means of total complexity for various periods of Somma-Vesuvius volcanic activity and the eruption power (size) is currently under investigation. At the surface conditions, ancient samples should contain a smaller number of water-soluble minerals than younger eruptions. This should lead to a decrease of the total number of minerals and consequently, to a decrease of total complexity during the geological time. On the other hand, some minerals could be a product of the alteration of initial chlorides at surface conditions. Such low-temperature $\left(\leq 50^{\circ} \mathrm{C}\right)$ minerals (i.e., boothite) contain a complex hydrogen bonding system, which leads to an increase of the total complexity for the low-T assemblages [90]. 


\section{Concluding Remarks}

Our investigation on Cu-bearing minerals from a collection of Somma-Vesuvius volcano minerals shows that the most widespread phases are the sulfates, followed by vanadates, hydroxyhalides, oxides, carbonates, silicates and finally, phosphates. This is not surprising in a fumarole environment, as also observed by Balić-Žunić et al. [35] for the whole of European volcanic occurrences, where the prevalence of sulfates as well as halides mineralizations over the other species is shown. Interestingly, as in the literature, in the investigated samples, the minerals formed by other base metal $(\mathrm{Pb}, \mathrm{Zn})$ are less widespread and represented by few mineral varieties compared to the $\mathrm{Cu}$-rich minerals. This could be due to different factors, such as crystal-chemical reasons. Indeed, Pekov et al. [6] affirmed that minerals composed of $\mathrm{Zn}, \mathrm{Mg}, \mathrm{Fe}, \mathrm{Pb}$, etc., in the same fumaroles do not demonstrate the distinctive crystal-chemical features shown by $\mathrm{Cu}$-bearing minerals, nor do they present such great diversity of both mineral species and structural aspects observed in the cupric phases. These authors stated that this difference is likely due to the influence of the Jahn-Teller effect on the crystal-chemical behavior of the $\mathrm{Cu}^{2+}$ cation [93], especially when its coordination is formed only by $\mathrm{O}^{2-}$ and $\mathrm{Cl}^{-}$ligands with no $\mathrm{OH}^{-}$ groups or $\mathrm{H}_{2} \mathrm{O}$ molecules. However, the predominance of $\mathrm{Cu}$ minerals over the $\mathrm{Pb}-\mathrm{Zn}$-bearing phases of the mineral assemblages of the Somma-Vesuvius volcano in a geochemical and volcanological perspective is currently under investigation.

From the structural complexity point of view, the most complex minerals are related to the sulfate mineralization (cryptochalcite and boothite). The diversity of $\mathrm{Cu}$ mineralization in the Vesuvius volcano (different structural types) is connected with the different combinations of four-, five- and sixfold $\mathrm{Cu}$-centred polyhedra in both fumarolic and supergene minerals. The most complex structures crystallize at temperatures up to $400{ }^{\circ} \mathrm{C}$ and the main factor, which lead to increasing complexity, is the presence of "additional oxygen" in the mineral formula.

Another aspect of interest provided by this study is the recognition of new copper minerals in the Somma-Vesuvius parageneses (i.e, cryptochalcite, natrochalcite, starovaite, tsumebite), as well as of interesting $\mathrm{Cu}$-bearing vs. $\mathrm{Cu}$-free minerals and related assemblages (i.e., litidionite-calcinaksite association). It is worth noting that some of these minerals are common secondary phases in supergene environments connected to primary base metal-bearing sulfides. However, more accurate studies on the selected copper minerals and related assemblages are in progress in order to decipher their crystal chemistry in connection with the petrological/geochemical/volcanological evolution. Hence, the present research contributes to a further update of the complex and unique mineralogy of this volcano and especially concerning the sublimate/alteration minerals, formed in a particular environment of high temperature and atmospheric pressure. Even though Vesuvius is one of the most studied volcanoes in the world, and remarkable in respect to the fumarolic minerals as well, the data provided by this research, as well as by the recent mineralogical surveys (i.e., $[41,58,64,65,68])$, lead to the prediction that new mineral discoveries will be carried out in the Cu-bearing assemblages.

Lastly, despite the fumarolic/alteration, Cu-bearing minerals at Vesuvius cannot be considered of economic relevance as a copper reservoir, as this kind of mineralizations is significant for the crystal chemistry of this base metal and for the definition of its mineralogical variants. All these datasets can be of interest for the knowledge of alteration byproducts of copper ore deposits (i.e., porphyry copper systems) and of (base) metal segregation processes.

Supplementary Materials: The following are available online at http://www.mdpi.com/2075-163X/9/12/730/s1, Figure S1: Map of Somma-Vesuvius volcano (southern Italy), with some of the localities cited in the text, Table S1: Crystallographic and complexity information of $\mathrm{Cu}$-bearing minerals from Somma-Vesuvius.

Author Contributions: Conceptualization, G.B.; software, G.B., T.L.P., R.d.G., L.D.; validation, G.B., C.P., N.M., T.L.P., P.C.; methodology and formal analysis, G.B., T.L.P., R.d.G., A.A., N.C., M.C.; investigation, G.B., C.P., N.M.; writing-original draft preparation, G.B.; writing—review \& editing, G.B., C.P., N.M.,T.L.P., P.C.; data curation, G.B., C.P.; funding acquisition, G.B., T.L.P.

Funding: This research was funded by Università di Napoli Federico II, Dipartimento di Scienze della Terra, dell'Ambiente e delle Risorse (DiSTAR, Napoli), no. "Ricerca Dipartimentale 2017-2018”, granted to G. Balassone. 
This study was also partially granted by the Russian Science Foundation (grant 19-17-00038 to T.L.P.) and by the Kola Science Center of Russian Academy of Sciences (Project 0226-2019-0011).

Acknowledgments: The authors thank two anonymous Reviewers for valuable comments and all the Editorial staff of Minerals for continous and skillful assistance. V. Monetti and L.M. Francese (DiSTAR, Università Federico II, Naples, Italy) are thanked for technical support in the analytical work. We are grateful to L. Assunto (Centro Museale "Centro Musei delle Scienze Naturali e Fisiche", Università Federico II, Naples, Italy), who kindly helped in handling the Museum samples. M. Piochi, A. Mormone and L. Pappalardo (INGV, Osservatorio Vesuviano, Naples, Italy) are thanked for useful discussions.

Conflicts of Interest: The authors declare no conflict of interest.

\section{References}

1. Rudnick, R.L.; Gao, S. The composition of the continental crust. In Treatise on Geochemistry; Holland, H.D., Turekian, K.K., Eds.; Elsevier-Pergamon: Oxford, UK, 2003; Volume 3, pp. 1-64.

2. White, W.W.; Klein, E.M. The composition of the oceanic crust. In Treatise on Geochemistry, 2nd ed.; Holland, H.D., Turekian, K.K., Eds.; Volume 4: The Crust; Elsevier-Pergamon: Oxford, UK, 2014; pp. 457-496.

3. Palme, H.; O'Neill, H. Cosmochemical estimates of mantle composition. In Treatise on Geochemistry; Holland, H.D., Turekian, K.K., Eds.; Elsevier-Pergamon: Oxford, UK, 2003; Volume 3, pp. 1-38.

4. Bindi, L.; Biagioni, C. A crystallographic excursion in the extraordinary world of minerals: The case of $\mathrm{Cu}-$ and Ag-rich sulfosalts. Acta Cryst. 2018, 74, 527-538. [CrossRef]

5. The Mineralogy of Copper. Available online: https://www.mindat.org/element/Copper (accessed on 1 May 2019).

6. Pekov, I.V.; Zubkova, N.V.; Pushcharovsky, D.Y. Copper minerals from volcanic exhalations-A unique family of natural compounds: Crystal-chemical review. Acta Cryst. 2018, 74, 502-518. [CrossRef]

7. Sillitoe, R.H. Porphyry copper systems. Econ. Geol. 2010, 105, 3-41. [CrossRef]

8. Chiaradia, M. Copper enrichment in arc magmas controlled by overriding plate thickness. Nat. Geosci. 2014, 7, 43-46. [CrossRef]

9. Williamson, B.J.; Herrington, R.J.; Morris, A. Porphyry copper enrichment linked to excess aluminium in plagioclase. Nat. Geosci. 2016, 9, 237-241. [CrossRef]

10. Russo, M.; Punzo, I. I Minerali del Somma-Vesuvio; Associazione Micro-Mineralogica Italiana Press: Cremona, Italy, 2004; pp. 1-317.

11. Russo, M. I minerali di Formazione Fumarolica della Grande Eruzione Vesuviana del 1906; Open File Report No. 6; Istituto Nazionale di Geofisica e Vulcanologia: Naples, Italy, 2006; pp. 1-40.

12. Russo, M.; Campostrini, I. Storia termica di una fumarola del Vesuvio (Campania, Italy) attraverso lo studio di minerali presenti su di un microcampione. Quad. Geofis. J. 2008, 52, 1-15.

13. Caliro, S.; Chiodini, G.; Avino, R.; Minopoli, C.; Bocchino, B. Long time-series of chemical and isotopic compositions of Vesuvius fumaroles: Evidence for deep and shallow processes. Ann. Geoph. 2011, 54, 137-149.

14. Chiodini, G.; Marini, L.; Russo, M. Geochemical evidence for the existence of high temperature hydrothermal brines at Vesuvio volcano, Italy. Geochim. Cosmochim. Acta 2001, 65, 2129. [CrossRef]

15. Angus, J.G.; Davis, G.R. Base metal enrichment in volcanic sublimates and secondary alteration products from Vesuvius and Vulcano. Mineral. Mag. 1976, 40, 481-486. [CrossRef]

16. Avanzinelli, R.; Cioni, R.; Conticelli, S.; Giordano, G.; Isaia, R.; Mattei, M.; Melluso, M.; Sulpizio, R. The Vesuvius and the other Volcanoes of Central Italy. Available online: http://www.isprambiente.gov.it/it/ pubblicazioni/periodici-tecnici/geological-field-trips (accessed on 26 November 2019).

17. Brocchini, D.; Principe, C.; Castradori, D.; Laurenzi, M.A.; Gorla, L. Quaternary evolution of the southern sector of the Campanian Plain and early Somma-Vesuvius activity: Insights from the Trecase 1 well. Mineral. Petrol. 2001, 73, 67-91. [CrossRef]

18. De Vivo, B.; Rolandi, G.; Gans, P.B.; Calvert, A.; Bohrson, W.A.; Spera, F.J.; Belkin, H.E. New constraints on the pyroclastic eruptive history of the Campanian volcanic Plain (Italy). Mineral. Petrol. 2001, 73, 47-65. [CrossRef]

19. Cioni, R.; Santacroce, R.; Sbrana, A. Pyroclastic deposits as a guide for reconstructing the multi-stage evolution of the Somma-Vesuvius Caldera. Bull. Volcanol. 1999, 61, 207-222. [CrossRef] 
20. Bertagnini, A.; Landi, P.; Rosi, M.; Vigliargio, A. The Pomici di Base Plinian eruption of Somma-Vesuvius. J. Volcanol. Geotherm. Res. 1998, 83, 219-239. [CrossRef]

21. Landi, P.; Bertagnini, A.; Rosi, M. Chemical zoning and crystallization mechanisms in the magma chamber of the Pomici di Base plinian eruption of Somma-Vesuvius (Italy). Contrib. Mineral. Petrol. 1999, 135, 179-197. [CrossRef]

22. Cioni, R.; Sulpizio, R.; Garruccio, N. Variability of the eruption dynamics during a Subplinian event: The Greenish Pumice eruption of Somma-Vesuvius (Italy). J. Volcanol. Geotherm. Res. 2003, 124, 89-114. [CrossRef]

23. Di Renzo, V.; Di Vito, M.A.; Arienzo, I.; Carandente, A.; Civetta, L.; D'Antonio, M.; Giordano, F.; Orsi, G.; Tonarini, S. Magmatic history of Somma-Vesuvius on the basis of new geochemical and isotopic data from a deep borehole (Camaldoli della Torre). J. Petrol. 2007, 48, 753-784. [CrossRef]

24. Santacroce, R.; Cioni, R.; Marianelli, P.; Sbrana, A.; Sulpizio, R.; Zanchetta, G.; Donahue, D.J.; Joron, J.L. Age and whole rock-glass compositions of proximal pyroclastics from the major explosive eruptions of Somma-Vesuvius: A review as a tool for distal tephrostratigraphy. J. Volcanol. Geotherm. Res. 2008, 177, 1-18. [CrossRef]

25. Rolandi, G.; Maraffi, S.; Petrosino, P.; Lirer, L. The Ottaviano eruption of Somma-Vesuvio (8000 y. B.P.): A magmatic alternating fall and flow-forming eruption. J. Volcanol. Geotherm. Res. 1993, 58, 43-65. [CrossRef]

26. Rolandi, G.; Mastrolorenzo, G.; Barrella, A.M.; Borrelli, A. The Avellino plinian eruption of Somma-Vesuvius (3760 y.B.P.): The progressive evolution from magmatic to hydromagmatic style. J. Volcanol. Geotherm. Res. 1993, 58, 67-88. [CrossRef]

27. Cioni, R. Volatile content and degassing processes in the AD 79 magma chamber at Vesuvius (Italy). Contrib. Mineral. Petrol. 2000, 140, 40-54. [CrossRef]

28. Cioni, R.; Civetta, L.; Marianelli, P.; Métrich, N.; Santacroce, R.; Sbrana, A. Compositional layering and syneruptive mixing of a periodically refilled shallow magma chamber: The AD 79 Plinian eruption of Vesuvius. J. Petrol. 1995, 36, 739-776. [CrossRef]

29. Santacroce, R.; Sbrana, A. The Vesuvius Geological Map; CARG Project; Servizio Geologico d'Italia: Naplesm, Italy, 2003.

30. Arrighi, S.; Principe, C.; Rosi, M. Violent strombolian and subplinian eruptions at Vesuvius during post-1631 activity. Bull. Volcanol. 2001, 63, 126-150. [CrossRef]

31. Joron, J.L.; Métrich, N.; Rosi, M.; Santacroce, R.; Sbrana, A. Chemistry and petrography. In Somma-Vesuvius; Santacroce, R., Ed.; Quaderni De La Ricerca Scientifica: Rome, Italy, 1987; Volume 8, pp. 105-174.

32. Ayuso, R.; De Vivo, B.; Rolandi, G.; Seal, R., II; Paone, A. Geochemicaland isotopic Nd-Pb-Sr-O variations bearing on the genesis of volcanic rocks from Vesuvius, Italy. J. Volcanol. Geotherm. Res. 1998, 82, 53-78. [CrossRef]

33. Pozas, J.M.; Rossi, G.; Tazzoli, V. Re-examination and Crystal Structure Analysis of Litidionite. Am. Mineral. 1975, 60, 471-474.

34. Ciriotti, M.E.; Fascio, L.; Pasero, M. Italian type minerals; Plus-Pisa University Press: Pisa, Italy, 2009; pp. 1-352.

35. Balić-Žunić, T.; Garavelli, A.; Jakobsson, S.P.; Jonasson, K.; Katerinopoulos, A.; Kyriakopoulos, K.; Acquafredda, P. Fumarolic minerals: An overview of active European volcanoes. In Updates in Volcanology_From Volcano Modelling to Volcano Geology; Nemeth, K., Ed.; InTech Open Access Publishers: London, UK, 2016; pp. 267-322.

36. Lacroix, A. Les minèraux des fumarolles de l'èruption du Vèsuve en Avril 1906. Bull. Soc. Française Minèral. Cristallogr. 1907, 30, 219-266.

37. Deville Saint-Claire, C. Observations sur la nature et la distribution des fumerolles dans l'eruption du Vesuve du 1. du 1855; Mallet-Bachier Imprimeur-Libraire: Paris, France, 1855; pp. 1-55.

38. Parascandola, A. I minerali del Vesuvio nella eruzione del marzo 1944 e quelli formati durante l'attuale periodo di riposo. Boll. Soc. Geol. Ital. 1951, 70, 513-526.

39. Parascandola, A. Notizie vesuviane. Il Vesuvio dal marzo 1948 al dicembre 1958. Boll. Soc. Nat. Napoli 1960, 68, 184.

40. Parascandola, A. Notizie vesuviane. Il Vesuvio dal gennaio 1959 al dicembre 1960. Boll. Soc. Nat. Napoli 1961, 69, 263-298.

41. Campostrini, I.; Demartin, F.; Russo, M. Sbacchiite, $\mathrm{Ca}_{2} \mathrm{AlF}_{7}$, a new fumarolic mineral from the Vesuvius volcano, Napoli, Italy. Eur. J. Mineral. 2019, 31, 153-158. [CrossRef] 
42. Altomare, A.; Corriero, N.; Cuocci, C.; Falcicchio, A.; Moliterni, A.; Rizzi, R. QUALX2.0: A qualitative phase analysis software using the freely available database POW_COD. J. Appl. Cryst. 2015, 48, 598-603. [CrossRef]

43. Altomare, A.; Cuocci, C.; Giacovazzo, C.; Moliterni, A.; Rizzi, R.; Corriero, N.; Falcicchio, A. EXPO2013: A kit of tools for phasing crystal structures from powder data. J. Appl. Cryst. 2013, 46, 1231-1235. [CrossRef]

44. Momma, K.; Izumi, F. VESTA: A three-dimensional visualization system for electronic and structural analysis. J. Appl. Cryst. 2008, 41, 653-658. [CrossRef]

45. Blatov, V.A.; Shevchenko, A.P.; Serezhkin, V.N. TOPOS 3.2: A new version of the program package for multipurpose crystal-chemical analysis. J. Appl. Cryst. 2000, 33, 1193. [CrossRef]

46. Krivovichev, S.V. Structural complexity of minerals: Information storage and processing in the mineral world. Mineral. Mag. 2013, 77, 275-326. [CrossRef]

47. Whitney, D.L.; Evans, B.W. Abbreviations for names of rock-forming minerals. Am. Mineral. 2010, 95, 185-187. [CrossRef]

48. Pekov, I.V.; Zubkova, N.V.; Agakhanov, A.A.; Yapaskurt, V.O.; Belakovskiy, D.I.; Vigasina, M.F.; Sidorov, E.G.; Pushcharovsky, D.Y. Cryptochalcite, IMA 2014-106. CNMNC Newsletter No. 25. Mineral. Mag. 2015, 79, 529-535.

49. Pekov, I.V.; Zubkova, N.V.; Agakhanov, A.A.; Pushcharovsky, D.Y.; Yapaskurt, V.O.; Belakovskiy, D.I.; Vigasina, M.F.; Sidorov, E.G.; Britvin, S.N. Cryptochalcite, $\mathrm{K}_{2} \mathrm{Cu}_{5} \mathrm{O}\left(\mathrm{SO}_{4}\right)_{5}$, and cesiodymite, $\mathrm{CsKCu}_{5} \mathrm{O}\left(\mathrm{SO}_{4}\right)_{5}$, two new isotypic minerals and the $\mathrm{K}-\mathrm{Cs}$ isomorphism in this solid-solution series. Eur. J. Mineral. 2018, 30, 593-607. [CrossRef]

50. Pekov, I.V.; Zubkova, N.V.; Agakhanov, A.A.; Yapaskurt, V.O.; Chukanov, N.V.; Belakovskiy, D.I.; Sidorov, E.G.; Pushcharovsky, D.Y. Dravertite, $\mathrm{CuMg}\left(\mathrm{SO}_{4}\right)_{2}$, a new mineral species from the Tolbachik volcano, Kamchatka, Russia. Eur. J. Mineral. 2017, 29, 323-330. [CrossRef]

51. Scacchi, A. Ricerche chimiche sulle incrostazioni gialle della lava vesuviana del 1631: Memoria prima; Accademia della Società di Scienze Fisiche e Matematiche: Napoli, Italy, 1879; pp. 1-10.

52. Pekov, I.V.; Zelenski, M.E.; Yapaskurt, V.O.; Polekhovsky, Y.S.; Murashko, M.N. Starovaite, $\mathrm{KCu}_{5} \mathrm{O}\left(\mathrm{VO}_{4}\right)_{3}$, a new mineral from fumarole sublimates of the Tolbachik volcano, Kamchatka, Russia. Eur. J. Mineral. 2013, 25, 91-96. [CrossRef]

53. Sabelli, C. Structure refinement of elpasolite from Cetine mine, Tuscany, Italy. Neues Jahrb. Mineral. Monatshefte 1987, 11, 481-487.

54. Campostrini, I.; Demartin, F.; Russo, M. Nuova segnalazione di minerali fumarolici al Vesuvio. Plinius 2014, 40, 149 .

55. Demartin, F.; Gramaccioli, C.M.; Campostrini, I. Thermessaite, $\mathrm{K}_{2}\left[\mathrm{AlF}_{3} \mid \mathrm{SO}_{4}\right]$, a new ino-aluminofluoride-sulfate from La Fossa crater, Vulcano, Aeolian Islands, Italy. Can. Mineral. 2008, 46, 693-700. [CrossRef]

56. Aksenov, S.M.; Rastsvetaeva, R.K.; Chukanov, N.K.; Kolitsch, U. Structure of calcinaksite $\mathrm{KNa}\left[\mathrm{Ca}\left(\mathrm{H}_{2} \mathrm{O}\right)\right]\left[\mathrm{Si}_{4} \mathrm{O}_{10}\right]$, the first hydrous member of the litidionite group of silicates with $\left[\mathrm{Si}_{8} \mathrm{O}_{20}\right]^{8-}$ tubes. Acta Cryst. 2014, B70, 768-775. [CrossRef]

57. Chukanov, N.V.; Aksenov, S.M.; Rastsvetaeva, R.K.L.; Blass, G.; Varlamov, D.A.; Pekov, I.V.; Belakovskiy, D.I.; Gurzhiy, V.V. Calcinaksite, $\mathrm{KNaCa}\left(\mathrm{Si}_{4} \mathrm{O}_{10}\right) \mathrm{H}_{2} \mathrm{O}$, a new mineral from the Eifel volcanic area, Germany. Mineral. Petrol. 2015, 109, 397-404. [CrossRef]

58. Russo, M.; Campostrini, I.; Castellano, F. Ritrovamento di atacamite in cristalli al Vesuvio. Micro 2011, 9 , 62-63.

59. Reich, M.; Barnes, J.D.; Breecker, J.D.; Barra, F.; Milojevic, C.; Drew, D.L. Chlorine isotope fractionation recorded in atacamite during supergene copper oxidation. Chem. Geol. 2019, 525, 168-176. [CrossRef]

60. Malcherek, T.; Welch, M.D.; Williams, P.A. The atacamite family of minerals-A testbed for quantum spin liquids. Acta Cryst. 2018, 74, 519-526. [CrossRef]

61. Dekov, V.; Boycheva, T.; Hålenius, U.; Petersen, S.; Billström, K.; Stummeyer, J.; Kamenov, G.; Shanks, W. Atacamite and paratacamite from the ultramafic-hosted Logatchev seafloor vent field $\left(14^{\circ} 45^{\prime} \mathrm{N}\right.$, Mid-Atlantic Ridge). Chem. Geol. 2011, 286, 169-184. [CrossRef]

62. Braithwaite, R.S.W.; Mereiter, K.; Paar, W.H.; Clark, A.M. Herbertsmithite, $\mathrm{Cu}_{3} \mathrm{Zn}(\mathrm{OH})_{6} \mathrm{Cl}_{2}$, a new species, and the definition of paratacamite. Mineral. Mag. 2004, 68, 527-539. [CrossRef] 
63. Mitchell, R.H.; Welch, M.D.; Chakhmouradian, A.R. Nomenclature of the perovskite supergroup: A hierarchical system of classification based on crystal structure and composition. Mineral. Mag. 2017, 81, 411-461. [CrossRef]

64. Demartin, F.; Campostrini, I.; Castellano, C.; Russo, M. Parascandolaite, $\mathrm{KMgF}_{3}$, a new perovskite-Type fluoride from Vesuvius. Phys. Chem. Miner. 2014, 41, 403-407. [CrossRef]

65. Balić-Žunić, T.; Garavelli, A.; Pinto, D.; Mitolo, D. Verneite, $\mathrm{Na}_{2} \mathrm{Ca}_{3} \mathrm{Al}_{2} \mathrm{~F}_{14}$, a new aluminum fluoride mineral from Icelandic and Vesuvius fumaroles. Minerals 2018, 8, 553. [CrossRef]

66. Perchiazzi, N.; Merlino, S. The malachite-rosasite group: Crystal structures of glaukosphaerite and pokrovskite. Eur. J. Mineral. 2006, 18, 787-792. [CrossRef]

67. Xin, J.; Chen, L.; Zhiyong, W. The effect of $\mathrm{Cu}-\mathrm{Zn}$ distribution in zincian malachite on the formation of individual $\mathrm{CuO}$ and $\mathrm{ZnO}$ particles. J. Therm. Anal. Calorim. 2019, 137, 1519-1525.

68. Russo, M.; Campostrini, I.; Blaß, G.; Schäfer, C.; Ciriotti, M.E. Prima segnalazione di sfalerite nelle fumarole del Vesuvio (Campania). MICRO 2008, 123-124.

69. Avdontceva, M.S.; Krzhizhanovskaya, M.G.; Krivovichev, S.V.; Yakovenchuk, V.N. High-temperature order-disorder phase transition in nacaphite, $\mathrm{Na}_{2} \mathrm{CaPO}_{4}$ F. Phys. Chem. Mineral. 2015, 42, 671-676. [CrossRef]

70. Grew, E.S.; Krivovichev, S.V.; Hazen, R.M.; Hystad, G. Evolution of Structural Complexity in Boron Minerals. Can. Mineral. 2016, 54, 125-143. [CrossRef]

71. Gurzhiy, V.V.; Tyumentseva, O.S.; Krivovichev, S.V.; Krivovichev, V.G.; Tananaev, I.G. Mixed Uranyl Sulfate-Selenates: Evolution of Structural Topology and Complexity vs Chemical Composition. Cryst. Growth Des. 2016, 16, 4482-4492. [CrossRef]

72. Rule, K.C.; Reehuis, M.; Gibson, M.C.R.; Ouladdiaf, B.; Gutmann, M.J.; Hoffmann, J.-U.; Gerischer, S.; Tennant, D.A.; Süllow, S.; Lang, M. Magnetic and crystal structure of azurite $\mathrm{Cu}_{3}\left(\mathrm{CO}_{3}\right)_{2}(\mathrm{OH})_{2}$ as determined by neutron diffraction. Phys. Rev. 2011, 83, 104401. [CrossRef]

73. Wells, A.F. The crystal structure of atacamite and the crystal chemistry of cupric compounds. Acta Cryst. 1949, 2, 175-180. [CrossRef]

74. Fleet, M.E. The crystal structure of paratacamite, $\mathrm{Cu}_{2}(\mathrm{OH})_{3} \mathrm{Cl}$. Acta Cryst. 1975, 31, 183-187. [CrossRef]

75. Cooper, M.A.; Hawthorne, F.C. The crystal structure of mottramite and the nature of $\mathrm{Cu} \leftrightarrow \mathrm{Zn}$ solid solution in the mottramite-Disclosite series. Can. Mineral. 1995, 33, 1119-1124.

76. Martin, F.D.; Müller-Buschbaum, H. Em neues Alkalimetall-Kupfer-Oxovanadat: $\mathrm{KCu}_{5} \mathrm{~V}_{30} \mathrm{O}_{13} / \mathrm{On}$ a New Alkaline Copper Oxovanadate $\mathrm{KCu}_{5} \mathrm{~V}_{3} \mathrm{O}_{13}$. Z. Naturforsch 1994, 49, 1137-1140. [CrossRef]

77. Kashaev, A.A.; Bakakin, V.V. The crystal structure of volborhite $\mathrm{Cu}_{3}(\mathrm{OH})_{2} \mathrm{~V}_{2} \mathrm{O}_{7} 2 \mathrm{H}_{2} \mathrm{O}$. Dokl. Akad. Nauk SSSR 1968, 181, 967-969.

78. Hawthorne, F.C.; Ferguson, R.B. Refinement of the crystal structure of kröhnkite. Acta Cryst. 1975, 31, 1753-1755. [CrossRef]

79. Bacon, G.E.; Curry, N.A. The water molecules in $\mathrm{CuSO}_{4} 5 \mathrm{H}_{2}$ O. Proc. R. Soc. Lond. 1962, 266, 95-108.

80. Carapezza, M.; Di Sanseverino, L.R. Crystallography and genesis of double sulfates and their hydrates. II. Structure, powder pattern and thermoanalysis of cyanochroite, $\mathrm{K}_{2} \mathrm{Cu}\left(\mathrm{SO}_{4}\right)_{2} \cdot 6 \mathrm{H}_{2} \mathrm{O}$. Mineral. Petr. Acta 1968, 14, 23-37.

81. Leverett, P.; McKinnon, A.R.; Williams, P.A. New data for boothite, $\mathrm{CuSO}_{4} \cdot 7 \mathrm{H}_{2} \mathrm{O}$, from Burranga, New South Wales. Aust. J. Mineral. 2004, 10, 3-6.

82. Menchetti, S.; Bindi, L.; Bonazzi, P. Disordered distribution of $\mathrm{Cu}$ in the crystal structure of leightonite, $\mathrm{K}_{2} \mathrm{Ca}_{2} \mathrm{Cu}\left(\mathrm{SO}_{4}\right)_{4} \cdot 2 \mathrm{H}_{2} \mathrm{O}$. Amer. Mineral. 2002, 87, 721-725. [CrossRef]

83. Giacovazzo, C.; Scandale, E.; Scordari, F. The crystal structure of chlorotionite, $\mathrm{CuK}_{2} \mathrm{Cl}_{2} \mathrm{SO}_{4}$. Zeit. Krist. 1976, 144, 226-237. [CrossRef]

84. Wildner, M.; Giester, G. Crystal structure refinements of synthetic chalcocyanite $\left(\mathrm{CuSO}_{4}\right)$ and zincosite (ZnSO $)_{4}$. Mineral. Petrol. 1988, 39, 201-209. [CrossRef]

85. Bachmann, V.H.G.; Zemann, J. Die kristallstruktur von linarit, $\mathrm{PbCuSO}_{4}(\mathrm{OH})_{2}$. Acta Cryst. 1961, $14,747-753$. [CrossRef]

86. Fanfani, L.; Zanazzi, P.F. Structural similarities of some secondary lead minerals. Mineral. Mag. 1967, 36, 522-529. [CrossRef]

87. Giester, G.; Zemann, J. The crystal structure of the natrochalcite-type compounds $\mathrm{Me}^{+} \mathrm{Cu}_{2}(\mathrm{OH})\left(\mathrm{ZO}_{4}\right)_{2} \mathrm{H}_{2} \mathrm{O}$ $\left(\mathrm{Me}^{+}=\mathrm{Na}, \mathrm{K}, \mathrm{Rb} ; \mathrm{z}=\mathrm{S}, \mathrm{Se}\right)$, with special reference to the hydrogen bonds. Zeit. Kristallogr. 1987, 179, 431-442. [CrossRef] 
88. Merlino, S.; Perchiazzi, N.; Franco, D. Brochantite, $\mathrm{Cu}_{4} \mathrm{SO}_{4}(\mathrm{OH})_{6}$ : OD character, polytypism and crystal structures. EJM 2003, 15, 267-275. [CrossRef]

89. Krivovichev, S.V.; Mentré, O.; Siidra, O.I.; Colmont, M.; Filatov, S.K. Anion-centered tetrahedra in inorganic compounds. Chem. Rev. 2013, 113, 6459-6535. [CrossRef]

90. Siidra, O.I.; Borisov, A.S.; Lukina, E.A.; Depmeier, W.; Platonova, N.V.; Colmont, M.; Nekrasova, D.O. Reversible hydration/dehydration and thermal expansion of euchlorine, ideally $\mathrm{KNaCu}_{3} \mathrm{O}\left(\mathrm{SO}_{4}\right)_{3}$. Phys. Chem. Mineral. 2019, 46, 403-416. [CrossRef]

91. Goldsmith, J.R. A “simplexity principle" and its relation to "ease" of crystallization. J. Geol. 1953, 61, $439-451$. [CrossRef]

92. Ivanyuk, G.Y.; Yakovenchuk, V.N.; Pakhomovsky, Y.A. Where are new minerals hiding? The main features of rare mineral localization within alkaline massifs. In Minerals as Advanced Materials II; Krivovichev, S., Ed.; Springer: Berlin/Heidelberg, Germany, 2011; pp. 13-24.

93. Burns, P.C.; Hawthorne, F.C. Static and dynamic Jahn-Teller effects in $\mathrm{Cu}^{2+}$-oxysalt minerals. Can. Mineral. 1996, 34, 1089-1105.

(C) 2019 by the authors. Licensee MDPI, Basel, Switzerland. This article is an open access article distributed under the terms and conditions of the Creative Commons Attribution (CC BY) license (http://creativecommons.org/licenses/by/4.0/). 